\title{
1. GRAIN-SIZE ANALYSIS AND DISTRIBUTION IN CASCADIA MARGIN SEDIMENTS, NORTHEASTERN PACIFIC ${ }^{1}$
}

\author{
A. Camerlenghi, ${ }^{2}$ R.G. Lucchi, ${ }^{3}$ and R.G. Rothwell ${ }^{4}$
}

\begin{abstract}
A study of the distribution of grain size and statistical parameters was made on 442 samples from all lithostratigraphic units at Ocean Drilling Program (ODP) Leg 146 drill sites. The aim of this study was (1) to provide calibration between the shipboard particle size analyzer (Lab-Tec100) and a widely used shore-based particle sizer (SediGraph 5000ET); and (2) to provide additional data useful for the identification of depositional environments, as tectonic and drilling disturbance and poor recovery prevented unequivocal shipboard interpretation.

Successful calibration of the two analytical methods was made on the fine fraction $(<125 \mu \mathrm{m})$ through identification of compensation factors on 33 samples. The row counts of particles provided by the Lab-Tec analyzer were converted to weight percent values according to the results of the SediGraph. The standard error of the calibrated compensation factors is minimum in the fine silts.

The distribution of grain size and statistical parameters (mean grain size, sorting [standard deviation], and skewness, particularly bivariate plots of skewness vs. sorting and sorting vs. mean size) discriminates lithological units that confirm the shipboard visual description. From this data, we conclude that Units I, II, and III of Hole 888B were deposited in a deep sea fan depositional environment (middle and outer fan) and Unit I of Hole 889A was deposited in a slope basin environment. Units II and III of Hole 889B and Unit I of Holes 891B and 892A, and 892D were deposited in a basin plain environment (outer fan), before tectonic uplift on the continental slope caused by accretionary processes on the Cascadia Margin.
\end{abstract}

\section{INTRODUCTION}

Sediments sampled on the continental slope of the Cascadia Margin during Ocean Drilling Program (ODP) Leg 146 are almost entirely visually monotonous sequences of silty clay and clayey silt. Drilling and tectonic disturbance of these sediments rarely allowed shipboard sedimentologists to easily identify the sedimentary structures or the depositional environment based on visual core description. The environment of deposition, suggested by the physiographic location, the seismic record, and sedimentary structures (preserved by the lack of disturbance), was clear only at Sites 888 and 889 (Fig. 1A).

Site 888 was drilled on the continental rise of the Vancouver Margin, in the upper part of a $2.5-\mathrm{km}$-thick sediment section, about $7 \mathrm{~km}$ seaward of the deformation front of the accretionary complex. The seismic record shows considerable lateral variation and frequent terminations of reflectors, with the development of channel-fill facies, and lobate, or wedge-shaped, acoustic units. In contrast with the lower (not drilled) part of the sediment section, which is composed of high-amplitude laterally continuous reflectors typical of distal turbidite sequences, the upper drilled section has been correlated to the mid-upper region of the Nitinat Fan (Site 888; Shipboard Scientific Party, 1994a). Of the three lithostratigraphic units, the upper and the lowest (Units I and III) are similarly composed of alternations of clayey silt and fine sand beds that reach $2 \mathrm{~m}$ in thickness. The middle Unit (II) is composed of massive beds of sand and clayey silt. In most of the recovered beds, it was possible to recognize fining-upward sequences, gradations, and sedimentary structures consistent with a turbiditic origin. From the application of the facies association model of

'Carson, B., Westbrook, G.K., Musgrave, R.J., and Suess, E. (Eds.), 1995. Proc. ODP, Sci. Results, 146 (Pt. 1): College Station, TX (Ocean Drilling Program)

2Osservatorio Geofisico Sperimentale, Dipartimento di Geofisica della Litosfera, P.O. Box 2011, Opicina, 34016 Trieste, Italy.

${ }^{3}$ Marine Geoscience Research Group, Department of Earth Sciences, UWCC P.O. Box 914, Cardiff CF1 3YE, United Kingdom.

${ }^{4}$ Institute of Oceanographic Sciences Deacon Laboratory, Brook Road, Wormley, Godalming, Surrey GU8 SUB, United Kingdom.
Mutti and Ricci Lucchi (1972), the "outer submarine fan association" was identified for Units I and III and the "middle fan association" was identified for Unit II (Shipboard Scientific Party, 1994a).

Unit I of Site 889 was drilled on the Vancouver Margin accretionary complex, in a gently undulated mid-slope plateau that corresponds to a wide infilled slope basin (15-20 km across) (Fig. 1A). The lithostratigraphic unit corresponds to a largely undeformed seismic unit with a basin-fill external shape and containing subparallel reflectors. Unit I overlies the discontinuous and irregular reflectors of the accreted sediments (Unit II) composed of clayey silts and silty clays interbedded with silt and fine sand turbidites. The environment of deposition is interpreted as terrigenous turbiditic sedimentation in a mid-slope basin (Shipboard Scientific Party, 1994b.)

All the other lithostratigraphic unit, in the drilled accreted sediments (Fig. 1B) are intensely affected by tectonic deformation, textural disturbance possibly caused by the dissociation of gas hydrates (Shipboard Scientific Party, 1994b, 1994c), by drilling-induced disturbance, and in one case (Site 891 ) by very poor recovery. As a consequence, the depositional environments are uncertain. By correlation with units previously sampled on Deep Sea Drilling Project (DSDP) Leg 18 (Kulm, von Huene, et al., 1973), by correlation with core samples, and from various sedimentological arguments (Shipboard Scientific Party, 1994b), the environment of deposition of Units II and III of Site 889, and Unit I of Sites 891 and 892 was interpreted as basin plain. The general term "basin plain" was used by shipboard scientists to identify the deep water depositional environment (including middle and outer fan) as opposed to the continental slope environment.

Grain-size analysis of a large population of samples obtained with modern and fast instruments has recently found an important application in the study of sedimentary processes and their environmental significance (Stow and Wetzel, 1990; Szczepan et al., 1991; Weedon and McCave, 1991; Jones et al., 1992; Lucchi and Camerlenghi, 1993; Rothwell et al., 1994; Sutherland and Lee, 1994).

The instrument available onboard the JOIDES Resolution, although belonging to the new generation of particle-size analyzers, is seldom used for large sample population applications (Janecek, 


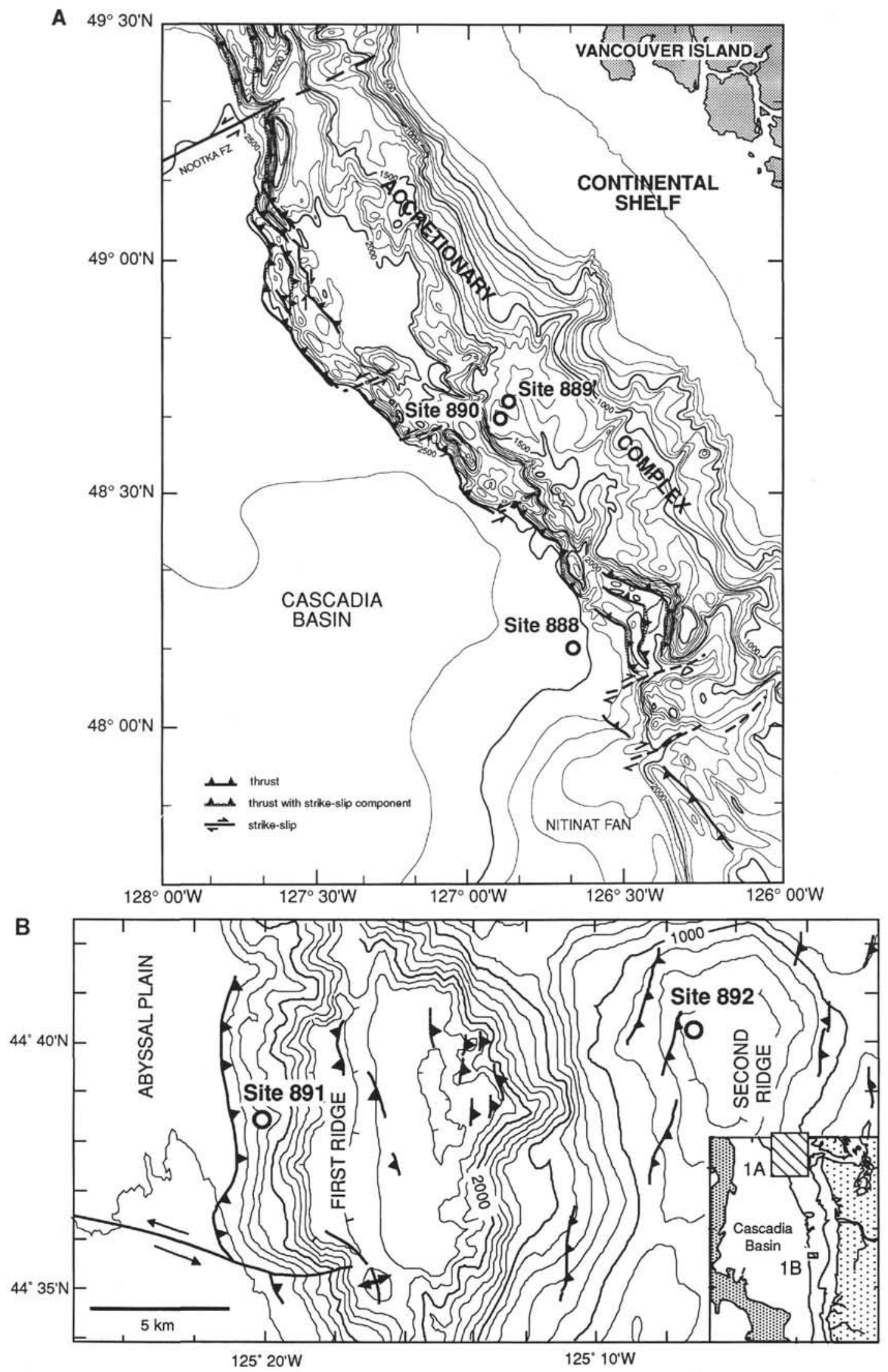

Figure 1. A. Location of Sites 888,889 , and 890 on the Vancouver Margin. Site 888 is located on the continental rise on the northern edge of the Nitinat deep sea fan. Sites 889 and 890 are located in the mid-slope basin (map and structural interpretation by Boris Baranov, Leg 146 shipboard party). B. Location of Sites 891 and 892 on the Oregon Margin. 
1993). A reason for this could be that the literature lacks studies on the capabilities of this instrument and comparative results with other, widely used, particle-sizers. Although several studies have focused on comparison between different particle-size analyzers (Singer et al., 1988 and references herein; Reinemann and Schemmer, 1993; Loizeau et al., 1994) none of them provides an example of data calibration between different instruments.

An intensive onboard sampling routine for grain-size analysis was initiated in order to obtain uniform sampling of all lithostratigraphic units. About one-half of the samples were processed aboard, and the remainder were processed during post-cruise laboratory work. This paper was conceived with two main objectives: (1) to provide an example of calibration between the shipboard grain-size analyzer (LabTec) and a shore-based laboratory instrument (SediGraph); and (2) to provide additional textural criteria (based on downhole grain-size distribution and correlation of statistical parameters) useful for identification of depositional environments, especially where drilling and tectonic disturbance had prevented unequivocal shipboard interpretation.

\section{ANALYTICAL METHODS}

\section{Sampling}

Four hundred and forty-two samples of about $1 \mathrm{~cm}^{3}$ were taken mainly from fine-grained sediments. Bases of turbidites were avoided as grain-size variability within these intervals is high and depends on the thickness of each bed. However, a number of samples from coarser grained beds were taken in order to compare the grain-size distributions of fine and coarse sediments. Furthermore, the shipboard instrument for grain-size analysis has an upper operational limit at $250 \mu \mathrm{m}$ (fine sand).

Sampling was therefore concentrated on the uniform, mainly structureless fine-grained sediments that are very common in the cored sequences. Visually, these were described as clayey silts or silty clays and had typically greenish-grayish hues. Samples were taken avoiding sedimentary structures such as graded beds, convolute lamination, and fining-upward sequences and are representative of the most common lithology with a density of at least two samples per core.

\section{Grain-size Measurements}

\section{Shipboard Analysis (LASENTEC Lab-Tec 100)}

The shipboard instrument is a LASENTEC Lab-Tec 100 particlesize analyzer, which uses a focused laser beam that is swept at constant velocity across a suspension of Calgon solution and sediment particles. The backscatter of light from the sediment particles is measured and peaks of intensity provide counts of particles divided in up to eight size classes of different diameters. The instrument measuring range is from clay to fine sands $(<250 \mu \mathrm{m})$. Counts can be converted into weight percentage by multiplying by a calibration factor $(F)$ that is found experimentally by comparison with grain-size curves of the same material obtained by a method that measures the weight of the particles of different diameters (typically called the "pipette method"). If such a calibration cannot be obtained, standard calibration factors can be applied in order to obtain realistic values of weight percentage. The grain-size values obtained onboard and included in the Initial Reports of Leg 146 (Westbrook, Carson, Musgrave, et al., 1994) are of this latter type. Calibration factors have been obtained during post-cruise analysis of the same material with a SediGraph 5000 ET particle sizer. The data presented in this paper are all corrected with these specific calibration factors.

The Lab-Tec analysis is fast and easy to perform, although it requires careful calibration of the focus of the laser beam; the operator must be acquainted with the optimum focus method for the laser beam during each analysis. About $0.5-1.0 \mathrm{~cm}^{3}$ of wet sample was dis- persed in $50 \mathrm{~mL}$ Calgon (sodium hexametaphosphate) solution prepared by adding $4 \mathrm{~g}$ of powder in $1 \mathrm{~L}$ of $18 \mathrm{M} \Omega$ distilled water. The suspension was handshaken to disaggregate the sediment particles and placed in ultrasonic bath for 15-30 min and then left to stand for $24 \mathrm{hr}$ with periodic shaking by hand before the analysis. The use of the sonic bath was considered safe for the fine sediments analyzed on board because of their extremely low bioclastic content. Sampling was focused on soft sediment, and layers showing diagenetic induration were avoided where possible. Samples of particularly indurated sediment were left in the sonic bath for a maximum of one hr for disaggregation. The resulting suspension was then poured into the 100 $\mathrm{mL}$ crystal beaker of the instrument and the volume made up by adding distilled water. The focus of the laser beam was adjusted manually inside the wall of the beaker while the suspension was magnetically stirred. This operation was aided by the graphic display of the intensity of the back-scatter provided on a IBM-compatible personal computer interfaced with the instrument. After focus adjustment, counting began and the next sample placed for analysis. The results (row count, weighted counts, and weight percentage of eight grain-size classes) were printed and later manually entered into a Macintosh computer for data processing. The grain-size classes analyzed bysthe instrument were: $<4,4-8,8-16,16-31,31-63,63-125$, $125-250$, and $>250 \mu \mathrm{m}$. The calibration factors adopted for the shipboard measurements were taken from the instrument's manual and are described below.

During Leg 146, 250 samples were analyzed for the purpose of this paper.

\section{Shore-based Analysis (SediGraph 5000E)}

The SediGraph 5000ET (Jones et al., 1988), used for the shorebased analysis, measures the attenuation of X-rays by the sediment particles suspended in a Calgon solution placed in a transparent cell. The X-ray beam scans the cell from top to bottom during the settling of the particles and determines a vertical profile of the density of the suspension. The density is converted to the weight percentage of grain size on the basis of Stoke's law. Each scan lasts about $15 \mathrm{~min}$. The general principle of the method is similar to that of the traditional pipette method, where the density is obtained by weighting the samples of the solution at different stages of settling.

The procedure adopted for our SediGraph 5000ET analyses consisted of dispersing $3-5 \mathrm{~cm}^{3}$ of wet sample in $20 \mathrm{~mL}$ plastic centrifuge tubes with a $5 \%$ Calgon solution. The tubes were mechanically shaken for $24 \mathrm{hr}$ in a rotating spindle. All the samples were wet sieved (Calgon solution) with a $63-\mu \mathrm{m}$ mesh prior to analysis. The fine fraction $(<63 \mu \mathrm{m})$ was analyzed using the SediGraph particle sizer. The sand and coarser fraction was dried, weighed, and then wet sieved using a sieve column composed of 63-, 70-, 90-, 125-, 180-, 250-, 350-, and $500-\mu \mathrm{m}$ mesh sizes. The partial residues retained by the sieves were dried and weighed. The difference between the weight of the fraction coarser than $63 \mu \mathrm{m}$ and the sum of the partial weights obtained with the second sieving was evenly distributed among the single grain-size classes.

Before SediGraph analysis, the suspension of the finer-than-63$\mu \mathrm{m}$ fraction was magnetically stirred for five minutes while the instrument was calibrated on a solution of $5 \%$ Calgon. Prior to analysis, the density of the suspension was checked as it was stirred. If the suspension was too dilute, the sample was discarded and the wt\% (obtained after desiccation at $100^{\circ} \mathrm{C}$ ) included in the clay fraction. This happened often with coarse samples in which very little fine fraction was present and caused bimodal distribution of grain sizes with extreme values of skewness. These samples were not considered in the statistical analysis of grain-size parameters but are listed in Appendix A. Most of the analyses were run in duplicate, with an excellent repetition of results.

The data output of the SediGraph 5000 ET is a cumulative curve of the weight percentage with a range of sizes from $0.68 \mu \mathrm{m}(10.5 \phi)$ 
to $63 \mu \mathrm{m}(4 \phi)$. Values of weight percentage were manually read every one-quarter $\phi$-classes, so that a total of 28 classes were determined in the fine fraction and entered in a Macintosh computer for further data processing.

Samples of particularly indurated sediment were left in Calgon solution for up to 15 days and if necessary, after observation of the particles under a microscope to check disaggregation, were placed in a sonic bath 5-10 $\mathrm{min}$ to complete the disaggregation process. The low microfossil content observed (about $5 \%$ ) allowed ultrasonic disaggregation of even coarse-grained samples.

All the SediGraph analyses were performed at the Institute of Oceanographic Sciences, Surrey, U.K. The total number of samples analyzed was 192 .

\section{CALIBRATION OF METHODS}

\section{Compensation Factors of the Lab-Tec 100}

The Lab-Tec measures the number of particles of a certain size class that intersect the focus of the laser beam during a one-, two-, to three-second reading time, repeated cyclically up to 10 times. With an optimum concentration of the suspension, up to about 65,000 counts per cycle can be obtained. The conversion from counts to weight is the most critical step in the analytical method.

A compensation factor, $F$, allows the weighted count to be obtained as

$$
\text { (raw count per cycle) } \times F=\text { weighted count. }
$$

The numerical value of $F$ varies for each grain-size class. For homogeneous material in which the shape of the grains approximate to a sphere, the relationship between weight and diameter can be determined through consideration of diameter and volume of spheres. In actual soils and sediments this relation should be experimentally determined by calibration of the row counts with the weight percentage determined on the same material with methods such as pipette, the SediGraph, or also by sieving or centrifuging. Numerical values of $F$ equal to the mid-point value of each size class (from fine to coarse: $2,3,6,12,24.5,47,94,188$ ) have been used in the past for shipboard analysis on biogenic carbonates (nannofossil oozes with foraminifers) during Leg 130 (Janecek, 1993) and during Leg 146. The application of these standard compensation factors is useful for identifying relative trends in the mean grain-size (such as those found at Sites 803 and 805, Leg 130, or those identified at several sites of Leg 146). However, the absolute size and the statistical parameters (sorting, skewness, kurtosis) cannot be correctly evaluated because the application of uncalibrated factors may greatly affect the shape of the grain-size spectrum.

In order to merge the two datasets collected using the Lab-Tec and the SediGraph, we reduced the 28 grain-size classes obtained using the SediGraph to the eight classes produced using the Lab-Tec, following the Udden-Wentworth grain-size scale for siliciclastic sedi- ments (Wentworth, 1922). We then calibrated $F$ for the data obtained using the SediGraph on 33 samples already analyzed with the LabTec. The procedure for calibration consisted of: (1) determination of the calibrated compensation factor by interactively multiplying row counts by a variable value of $F$, until the resulting weight percentage matches that obtained with the SediGraph (Table 1); (2) for each lithostratigraphic unit, at least one sample was chosen for calibration (bold figures in Appendix B), with values of $F$ applied to all the other samples of the same unit. Where more samples per unit were available, the values of $F$ were averaged between two adjacent calibrated samples and applied to all the samples included in the corresponding interval (see Appendix B).

\section{Results of Calibration}

The calibrated compensation factors show some variability and, in general, their values differ substantially from the standard values described in the previous section and adopted for shipboard analysis (see Appendix B).

The principal effect of calibration of Lab-Tec data was a decrease in mean grain size of about $4 \mu \mathrm{m}$ and the consequent shift of all the samples from the fine-silt to the very-fine-silt class (Fig. 2). Similarly, Singer et al. (1988) noted that Sedigraph data were typically shifted towards the finer fraction with respect to the results obtained with other four different particle-size analyzers.

The two coarsest grain-size fractions detected with the Lab-Tec (fine and medium sand) have been reduced to almost negligible values after the application of the calibrated compensation factors. The absence of sand fraction in the samples is confirmed by the absence of residues after wet sieving with $63-\mu \mathrm{m}$ mesh prior to SediGraph analysis. We believe that the decrease of mean size observed in the calibrated Lab-Tec results is real, and that the shipboard standard compensation factors were clearly too large for the terrigenous sediments of the Cascadia Margin.

More important, after calibration we find no systematic deviation between the two methods in the clay and silt classes (Fig. 3), and weak downhole trends of grain-size composition, if present in the SediGraph results, are also shown in the calibrated Lab-Tec results.

Figure 4 shows the standard error of the calibration factors (Table 2) plotted vs. grain size for each lithostratigraphic unit. The maximum error is in the coarsest grain-size fraction; it decreases to a minimum in fine silt and increases again (with only two exceptions) in the clay fraction. The presence of analogous trends of the error between units suggests that the lithostratigraphic units are composed of sediments with consistent behavior with respect to grain-size distribution or, possibly, that the error is not randomly distributed in all the samples analyzed, but varies consistently from unit to unit.

The calibration of the two methods can therefore be made with confidence in the silt and clay fractions. We have no data to support the application of the method to coarser grain sizes, because coarsegrained samples were analyzed only with the SediGraph.

We therefore recommend that shipboard Lab-Tec grain-size analyses should always be calibrated.

Table 1. Calibration of compensation factors for Sample 146-888B-40H-1, $27 \mathrm{~cm}$ (348.27 mbsf).

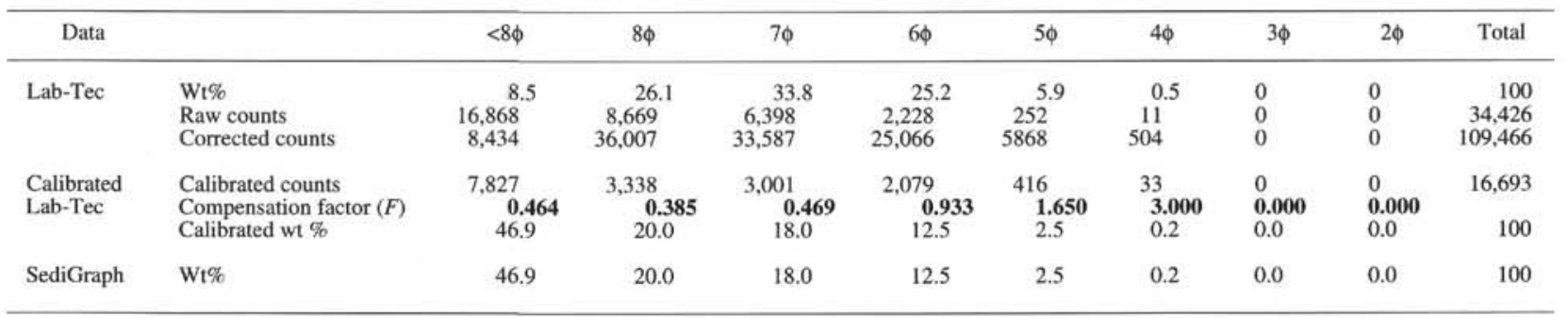

Notes: Calibrated counts $=$ raw counts $\times$ compensation factors; calibrated wt $\%=($ calibrated counts/total calibrated counts $) \times 100$; compensation factor: manually varied until calibrated $w t \%=$ SediGraph $w t \%$. 


\section{GRAIN-SIZE DISTRIBUTION \\ Downhole Distribution of Grain Size and Statistical Parameters}

All the data presented and discussed in this paper result from the merging of the SediGraph and Lab-Tec datasets after calibration. In the plots of the downhole grain-size distribution, different symbols represent the different lithostratigraphic units as they were described on board, and no distinction is made between analytical methods.

The statistical parameters mean size, sorting (standard deviation), and skewness have been calculated on eight grain-size classes using moment methods (McManus, 1988).

At Hole 888B (Fig. 5) there is a general uniformity in the downhole grain-size distribution. A weak trend of downward-increasing sand and mean size towards the bottom of Unit I reflects the occurrence of sand beds in the underlying transitional unit. A comparable trend of increasing hole diameter (Shipboard Scientific Party, 1994a, fig. 21) confirms that coarser material is present at the base of the unit. No significant information is apparent in the downhole logs obtained at this site. Samples from coarse sandy beds, which plot as data

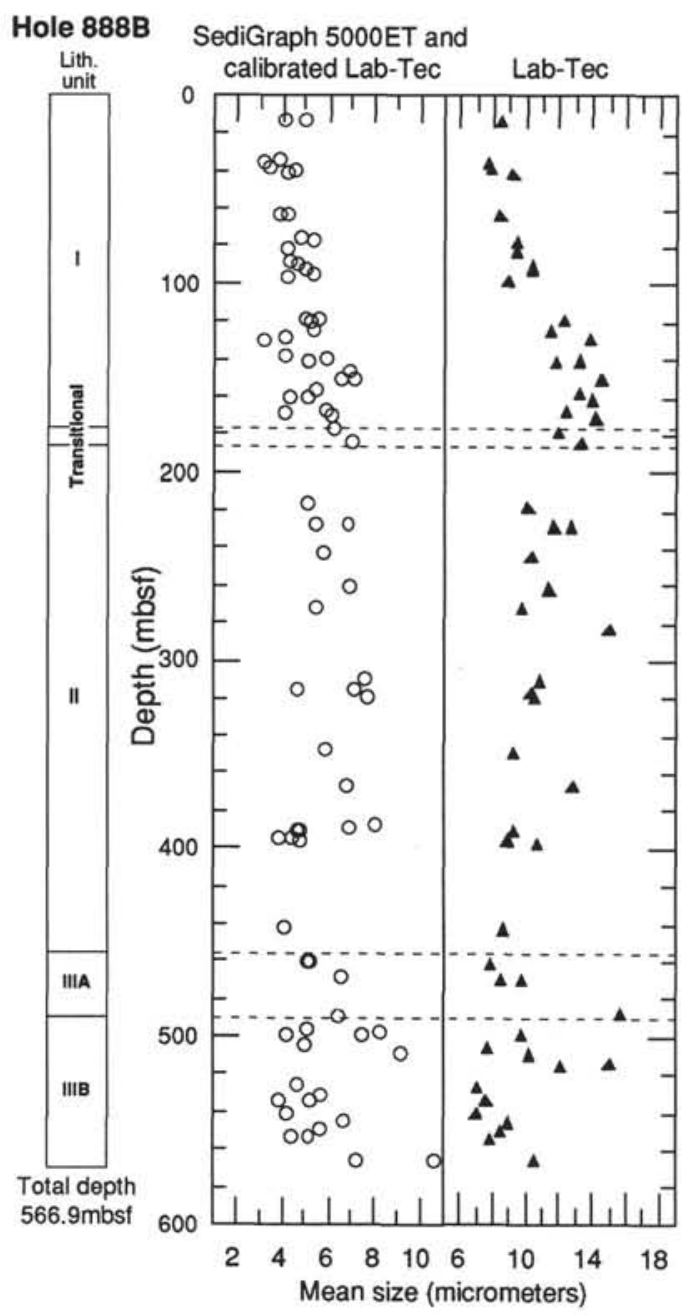

Figure 2. Comparison between the sediment mean grain size before and after calibration. Note that calibration produces a considerable decrease of the mean grain size. The trend in Unit I observed with the uncalibrated Lab-Tec is attenuated after calibration. The graphic log on the left follows the shipboard subdivision of units (Shipboard Scientific Party, 1994a). points near the zero value in the clay and silt logs (Fig. 5A), were extremely negatively skewed and were removed from the skewness log to facilitate data analysis.

At Holes 889A and 890B (Fig. 6), a marked difference exists in the silt, clay, and skewness distributions between Unit I and Unit II. This difference is shown particularly by the fine and very fine silts, and the boundary between the two units is extremely sharp (Fig. 6B). The distribution of the sand and mean size allows us to identify Subunit IB as an interval of sediment with a uniform distribution of parameters. Data coverage from Unit III is insufficient.

At Hole 891B (Fig. 7), the distribution of parameters is rather uniform in the whole of the cored section (composed of only one lithostratigraphic unit subdivided into three subunits). The boundary between Subunits IA and IB is distinguished by an increase in the sand fraction, decreasing sorting values, a change toward more negatively skewed values, and a different distribution of the silt size classes (Fig. 7B).

At Holes 892A and 892D (Fig. 8), the distribution of parameters is also fairly uniform. A break in the distribution patterns is observed near the boundary between Subunits IA and IB of Hole 892A. This break is marked by a decreasing clay and increasing silt content (particularly coarse and medium silt) at the base of Subunit IA.

The downhole distribution of grain size and statistical parameters confirms the subdivision of units identified on board (Westbrook, Carson, Musgrave, et al., 1994). With the exception of Sites 889/890, no major downhole lithologic breaks are present. Site 888 is composed of three units all deposited in the same deep-sea fan environment, and the sites drilled on the Oregon Margin are composed of only one lithologic unit. Where a major break in lithology has been inferred from shipboard observations (between Units I and II at Site 889 , deposited in the slope basin and in the abyssal plain environments, respectively) the distributions of grain size and statistical parameters show distinctive variations and are effective tools for identification of lithologic changes.

Significant differences can be observed in the distribution of the fine grain-size fraction (silt and clay). The samples collected in the coarse sandy beds have provided useful information for the downhole sand distribution.

\section{Bivariate Plots and Correlation between Statistical Parameters}

In order to further discriminate between units and subunits within each drill site, we constructed bivariate plots of combined grain-size statistical parameters. This method has been applied to datasets in the past, often with ambiguous results (see, for example, the discussion in Pettijohn, 1957 or McManus, 1988 and references herein). However, the method has been applied, to mainly shallow marine and coastal deposits (Gao et al., 1994; Medina et al., 1994; Antia, 1993).

In our case we attempt to discriminate between sediment particles of similar source deposited via turbidity currents in deep-sea fan and slope-basin of the same depositional system. The sedimentary regime of the continental rise and abyssal plain of the Cascadia Margin seems to have been rather uniform through time and is mainly terrigenous turbiditic, alternating with hemipelagic, deposition.

The usefulness of the application of bivariate plots of grain-size statistical parameters to understanding deep sea depositional environments is substantiated by the observation of systematic textural variations in fine-grained turbidites across the continental slope of the Scotian Margin (Stow, 1979).

In Figure 9 the bivariate plots of skewness vs. sorting and sorting vs. mean size (expressed in $\phi$ units) are grouped for all sites. Lithostratigraphic units and subunits are represented by different symbols and are separated (with the exception of a few scattered points) by empirically placed dashed lines. 


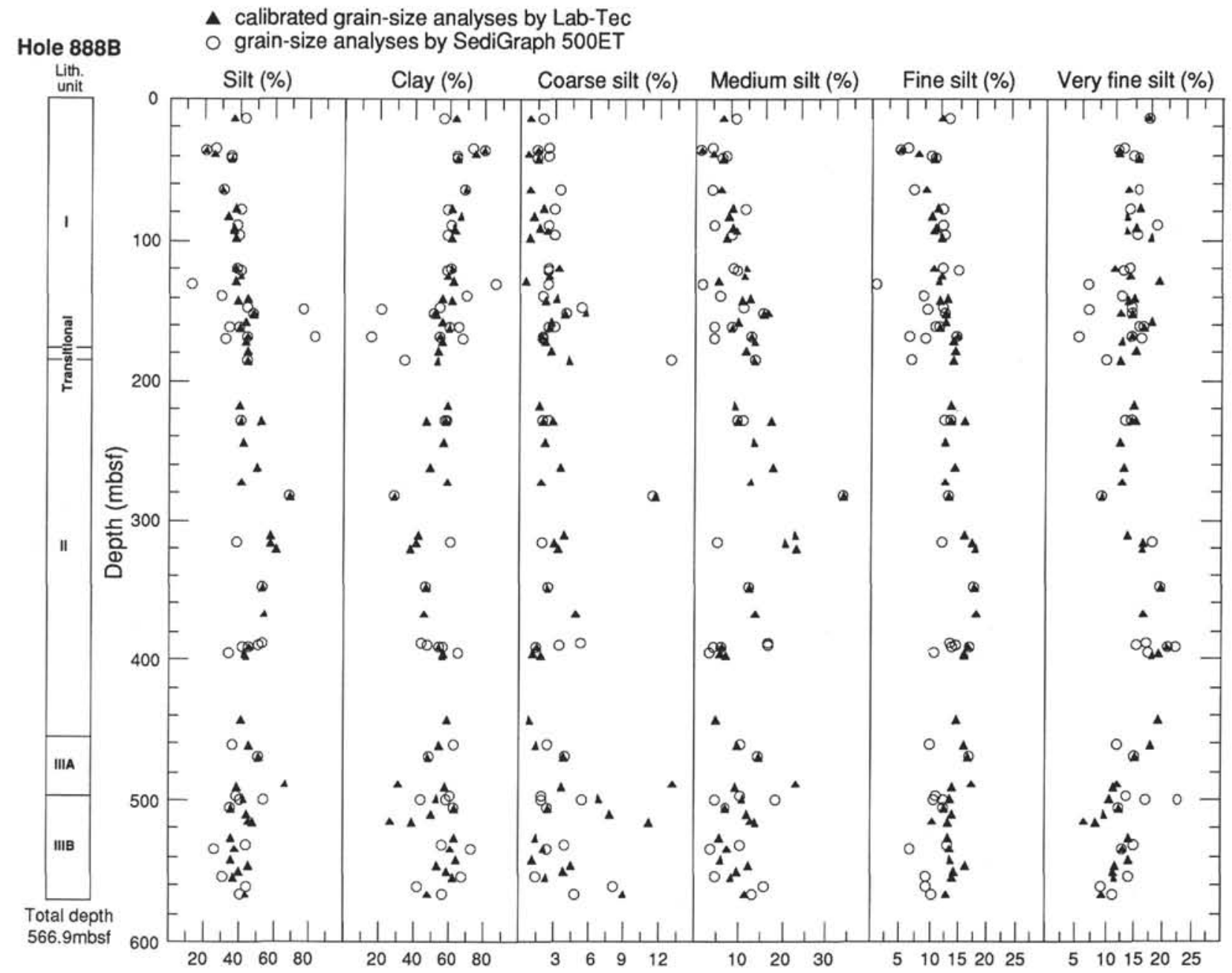

Figure 3. Example of overlap between calibrated Lab-Tec grain-size data and SediGraph 5000ET data. The comparison is only available for fine-grained sediments $(<125 \mu \mathrm{m})$, as the coarse fraction has not been analyzed with the Lab-Tec. Note the almost complete overlap of most of the samples. The graphic log on the left follows the shipboard subdivision of units (Shipboard Scientific Party, 1994a).

At Hole 888B (drilled at the Nitinat Fan), Units I and III are clearly separated from Unit II in the sorting vs. mean size plot. The upper part of Unit III (Subunit IIIA) plots ambiguously with Unit II in the skewness vs. sorting plot. In agreement with the original interpretation of middle fan (lobe) depositional environment, Unit II is characterized by lower mean size $\phi$ values (coarser material), a frequency curve less negatively skewed (tail in the fine material), and better sorting with respect to mean grain size than Units I and III, deposited in the outer fan.

At Holes $889 \mathrm{~A} / 890 \mathrm{~B}$ (drilled in a slope-basin) Units II and III are distinct from Unit I in both plots. Unit I of Hole 890B is located at both sides of the dashed line of separation between the Hole $889 \mathrm{~A}$ units. Unit I of Hole 889A, deposited in a slope basin environment, is characterized by higher mean grain-size $\phi$ values (finer material) and a frequency curve more negatively skewed (tail in the coarse material). The unit is also characterized by poorer sorting with respect to mean size. Units II and III, interpreted as basin plain deposits, are characterized by a coarser mean size, less negatively skewed frequency curve, and better sorting.

Hole 891B (drilled near the mouth of deep sea canyon) had very poor recovery and what was recovered had a uniform lithology (only one unit was described on board). Subunit IA is distinguished from the other two subunits by higher mean grain-size $\phi$ values (finer ma- terial), a less negatively skewed frequency curve (highest values of skewness found in our study), and better sorting with respect to mean size.

At Holes 892A and 892D (drilled on the upper continental slope) the data of the only unit identified on board (Unit I) plot in the same family of values and there is no distinction between subunits.

\section{Correlation between Sites}

The bivariate plots of Figure 9 allow better discrimination among the lithologic units and subunits at each site than the downhole plots of Figure 5 to 8 . We combined units with obscure environmental significance and those better known (namely: Hole 888B Units I, II, and III; Hole 889A Unit I) (Figs. 10 and 11). All the units and subunits are grouped in three main fields on skewness vs. sorting and sorting vs. mean size plots, each identified by different angular coefficients of straight lines (separated by double lines in Figs. 10 and 11). The data converge on common intercept values on the skewness and mean grain-size axes.

Best discrimination is provided by the skewness vs. sorting plot (Fig. 10). The three units of Hole 888B (deposited in a deep-sea fan environment) plot in the field limited by lines 1 and 2 . In the same field are located Units II and III of Hole 889A, Subunits IB and IC of 


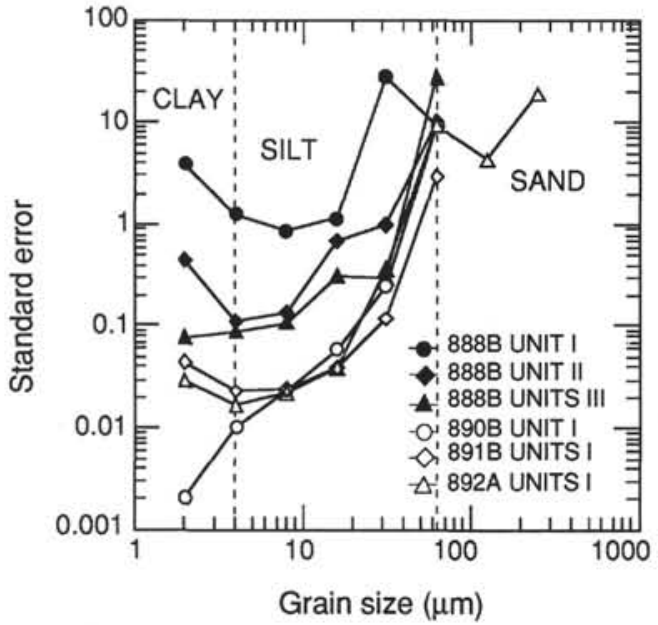

Figure 4. Standard error of the Lab-Tec compensation factor $(F)$ after calibration with the SediGraph 5000ET. Note that the standard error increases with grain size and is typically lowest in the fine-silt classes.

Hole 891B, and Unit I of Holes 892A and 892D. Unit I of Hole 889A (deposited in the slope basin environment) plots in the field below line 2 . In the same field are located only a few samples of Unit I of Hole $890 \mathrm{~B}$. The remaining samples from Hole $890 \mathrm{~B}$ Unit I are located in the same field as Hole 888B. Subunit IA of Hole 891B (in which reworking of sediments has been observed) plots in the third field above line 1. This major discrimination in three fields is reflected also in the plots of sorting vs. mean size (Fig. 11). In addition, in the skewness vs. sorting plots Units I and III of Hole 888B (outer fan) are located in two different subfields (separated by the dashed line). Units II and III of Hole 889A plot in the same subfield as Unit I of Hole 888B.

The core logs in the lower part of Figure 10 and 11 synthesize the subdivision of units and subunits based on the fields identified on the bivariate plots.

\section{DISCUSSION}

\section{Lithostratigraphic Units and Environmental Significance}

The bivariate plots of statistical parameters confirm the shipboard identification of lithostratigraphic units and their environmental interpretation based on the visual description of cores. Accordingly, the units drilled on the Oregon Margin at Sites 891 and 892 and the lower units of Site 889 were probably deposited in abyssal plain environment, possibly a deep-sea fan, analogous to the environment of deposition at Site 888. In particular, Subunits IB and IC of Hole 891B show a skewness vs. sorting relations identical to Unit II of Hole $888 \mathrm{~B}$. We suggest that they were also deposited in a middle fan lobe environment. The recovery at Site 891 was very poor (average recovery was about $11 \%$ ) and downhole logging suggests that the overall grain size at the site is coarser than observed in the cores (Shipboard Scientific Party, 1994c) and likely similar to Unit II of Site 888. The proximal setting of the two lower subunits of Site 891 is also suggested by the location of the site at the base of the continental slope, by the presence of the slumped deposits in the overlying Subunit IA, and by results of electrical logging (Shipboard Scientific Party, 1994c). While the middle fan Unit II of Site 888 has not been affected by tectonic processes, the sedimentary column at Site 891 , originally deposited in the basin plain seaward of the front of deformation, has undergone uplift and erosion due to the accretionary processes, and is now located at the toe of the continental slope on the hanging wall of a thrust fault. This inherited tectonic disturbance probably resulted in the poor recovery and loss of the prevailing coarse fraction of the sequence, and therefore the grain-size distribution in the fine-grained sediments, recovered by drilling, retains sufficient information for the identification of the environment of deposition.

The other units that were deposited in the basin plain environment (Hole 889A Units II and III and Holes 892A and 892D Unit I) show grain-size statistical parameters analogous to the finer Unit I of Site 888 deposited in the distal outer fan environment. Similar Pliocene and Pleistocene abyssal plain silt turbidites are found in the northern Cascadia Basin (Carlson and Nelson, 1987) and suggest possible correlation with the units found tectonically uplifted on the accretionary complex.

Table 2. Statistics of the calibrated compensation factors $(F)$.

\begin{tabular}{|c|c|c|c|c|c|c|c|c|}
\hline & $>8 \phi$ & $8 \phi$ & $7 \phi$ & $6 \phi$ & $5 \phi$ & $4 \phi$ & $3 \phi$ & $2 \phi$ \\
\hline \multicolumn{9}{|l|}{ Hole $888 \mathrm{~B}$} \\
\hline \multicolumn{9}{|l|}{ Unit I $(n=5)$} \\
\hline Minimum: & 0.72 & 0.26 & 0.25 & 0.71 & 1.54 & 0.00 & 0.00 & 0.00 \\
\hline Maximum: & 21.50 & 7.00 & 5.00 & 7.00 & 140.00 & 45.00 & 0.00 & 0.00 \\
\hline Mean: & 6.02 & 2.23 & 1.76 & 2.76 & 30.71 & 17.95 & 0.00 & 0.00 \\
\hline Standard error: & 3.93 & 1.25 & 0.86 & 1.15 & 27.34 & 9.18 & 0.00 & 0.00 \\
\hline \multicolumn{9}{|l|}{ Unit II $(n=4)$} \\
\hline Minimum: & 0.46 & 0.39 & 0.47 & 0.70 & 1.65 & 0.00 & 0.00 & 0.00 \\
\hline Maximum: & 2.52 & 0.89 & 1.06 & 3.79 & 5.70 & 45.00 & 0.00 & 0.00 \\
\hline Mean: & 1.23 & 0.58 & 0.73 & 1.87 & 3.41 & 15.50 & 0.00 & 0.00 \\
\hline Standard error: & 0.45 & 0.11 & 0.14 & 0.71 & 1.01 & 10.28 & 0.00 & 0.00 \\
\hline \multicolumn{9}{|l|}{ Unit III $(n=2)$} \\
\hline Minimum: & 0.46 & 0.18 & 0.35 & 0.83 & 3.50 & 4.88 & 0.00 & 0.00 \\
\hline Maximum: & 0.61 & 0.36 & 0.56 & 1.46 & 4.10 & 60.00 & 0.00 & 0.00 \\
\hline Mean: & 0.54 & 0.27 & 0.46 & 1.15 & 3.80 & 32.44 & 0.00 & 0.00 \\
\hline Standard error: & 0.08 & 0.09 & 0.11 & 0.32 & 0.30 & 27.56 & 0.00 & 0.00 \\
\hline \multicolumn{9}{|l|}{ Hole $890 \mathrm{~B}$} \\
\hline \multicolumn{9}{|l|}{ Unit I $(n=4)$} \\
\hline Minimum: & 0.23 & 0.07 & 0.04 & 0.12 & 1.20 & 7.31 & 0.00 & 0.00 \\
\hline Maximum: & 0.24 & 0.11 & 0.15 & 0.37 & 2.30 & 51.00 & 0.00 & 0.00 \\
\hline Mean: & 0.24 & 0.09 & 0.09 & 0.29 & 1.69 & 26.83 & 0.00 & 0.00 \\
\hline Standard error: & 0.00 & 0.01 & 0.02 & 0.06 & 0.25 & 9.13 & 0.00 & 0.00 \\
\hline \multicolumn{9}{|l|}{ Hole 891B } \\
\hline \multicolumn{9}{|l|}{ Unit $I(n=7)$} \\
\hline Minimum: & 0.06 & 0.04 & 0.06 & 0.07 & 0.23 & 0.00 & 0.00 & 0.00 \\
\hline Maximum: & 0.33 & 0.19 & 0.24 & 0.36 & 0.96 & 22.00 & 0.00 & 0.00 \\
\hline Mean: & 0.16 & 0.09 & 0.10 & 0.18 & 0.51 & 5.04 & 0.00 & 0.00 \\
\hline Standard error: & 0.04 & 0.02 & 0.02 & 0.04 & 0.12 & 2.93 & 0.00 & 0.00 \\
\hline \multicolumn{9}{|l|}{ Hole $892 \mathrm{~A}$} \\
\hline \multicolumn{9}{|l|}{ Unit I $(\mathrm{n}=9)$} \\
\hline Minimum: & 0.11 & 0.07 & 0.09 & 0.19 & 0.59 & 0.00 & 0.00 & 0.00 \\
\hline Maximum: & 0.34 & 0.20 & 0.29 & 0.58 & 4.20 & 90.00 & 39.00 & 170.00 \\
\hline Mean: & 0.24 & 0.14 & 0.17 & 0.31 & 1.49 & 24.92 & 4.33 & 18.89 \\
\hline Standard error: & 0.03 & 0.02 & 0.02 & 0.04 & 0.37 & 9.39 & 4.33 & 18.89 \\
\hline
\end{tabular}




\section{A Hole $888 \mathrm{~B}$}

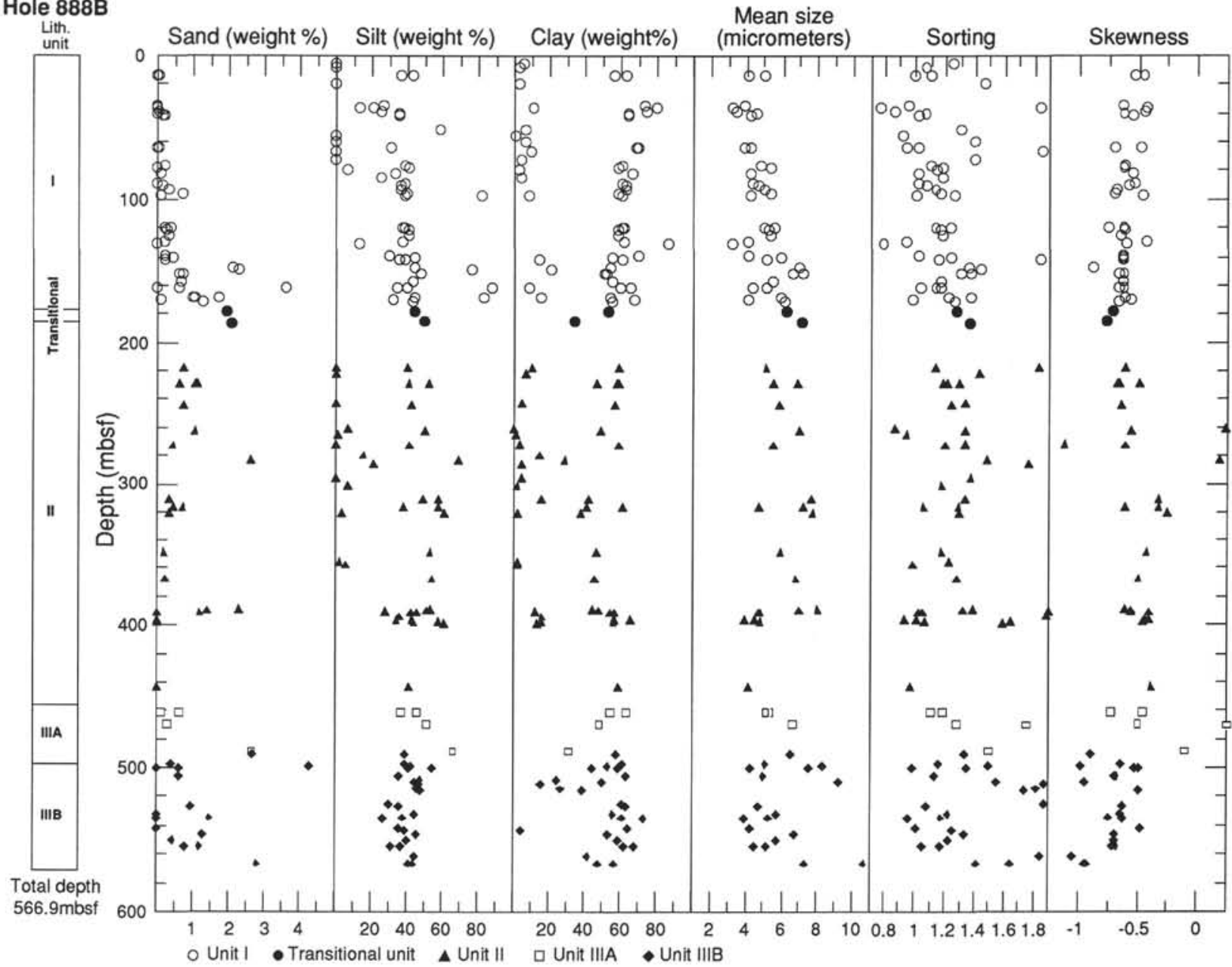

Figure 5. Downhole distribution of (A) grain size and statistical parameters and (B) silt classes distribution obtained with the SediGraph 5000ET and calibrated Lab-Tec analyses at Hole 888B. Different symbols refer to the units indicated in the graphic log on the left (after Shipboard Scientific Party, 1994a). See text for discussion.

At Site 889 a change in the environment of deposition from outer fan to slope basin is identified at the boundary between Units II and I. This significant boundary marks the transition from the uplifted basin plain Units II and III to slope basin Unit I. The change seems to be recorded in Subunit IB, where tilted beds and mud clasts indicate the occurrence of slope instability. The presence of a stratigraphic hiatus at the bottom of Subunit IA indicates that the erosion of sediments may have accompanied such a transition. The seismic record at Site 889 (Shipboard Scientific Party, 1994b, fig. 4) shows that the deposition of Subunit IB occurred under the influence of syndepositional tectonics (landward-dipping reverse faults); the initial estimate of the timing of this tectonic and sedimentary event is in the range of 0.45-1.05 Ma (Shipboard Scientific Party, 1994b). The strong difference in environment of deposition present at Site 889 is reflected in the marked differences between downhole distribution of grain-size parameters (Fig. 6) and in the identification of line 2 of the field separation in Figures 10, 11, and 12. The lack of slope basin sediments overlying the uplifted basin plain deposits on the Oregon Margin agrees with the seismic record; either the slope has not been significantly affected by sedimentation or this margin, unlike the Washington Margin, is presently undergoing intense near-surface erosion.

Of all the sites drilled, units attributed to slope basin deposition are only present at Site 889 (Unit I) and Site 890 (Unit I). Hole 890B represents the uppermost, not drilled section of the slope basin drilled deeply at Site 889 and is characterized by higher mean grain size. However, the location of Site 890 is on the seaward side of a tectonically uplifted seafloor mound, offset a few kilometers from Site 889, therefore not strictly belonging to the same basin. Samples from the upper part of Site 890 (Unit I') fall in the same field as Unit I of Site 889 in the bivariate plots (below line 2 in Fig. 10). The lowest samples (Unit $\mathrm{I}^{\prime \prime}$ ) instead plot across the line, together with the various basin plain units drilled on the margin. Because there are no lithologic criteria to distinguish between Units I of the two sites, nor geochemical or physical-properties parameters, we can only suggest that Site 890 crossed an otherwise undocumented unconformity between recent slope basin sediments and older basin plain sediments uplifted on the margin.

The lithology of Subunit IA, Hole 891B, in which convoluted, folded and inclined beds associated to mud clasts were found, bears similarities with the "pebbly mud" or "fluxoturbidites" (Nelson, 1976 and references therein) of the upper-fan valleys of the Astoria fan, characterized by more positive skewness and poor sorting. These deposits, generally included in the term "sediment gravity flows" and recurrent at the base of the slope of the Astoria fan, have been attributed to sedimentary processes transitional between mass movements and well-developed turbidity currents, which range from slumping to sediment flow over short distances in association with developing turbidity flows. Although the behavior of skewness in these deposits 


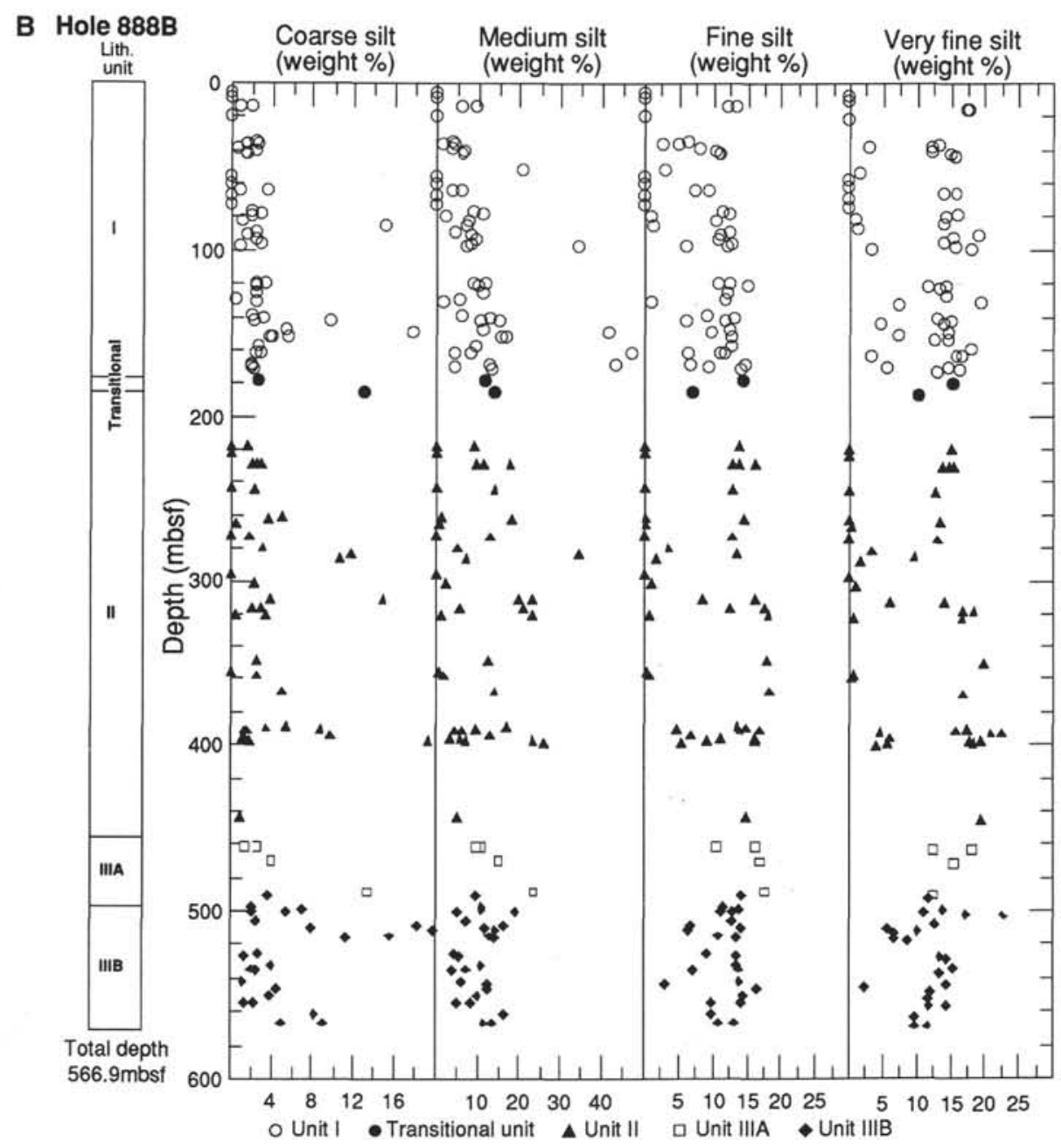

Figure 5 (continued).

matches the skewness of our Subunit IA, sorting, being better than in the underlying Subunits IB and IC, is apparently contradicting. We think that sampling of the finest fraction in this case may not be representative of the bulk sediment structure.

\section{Grain-size Trends in the Direction of Sediment Transport}

Of the three main fields in the bivariate plots, two (basin plain and slope basin) allow us to identify the grain-size characteristics typical of the Cascadia Margin (Fig. 12). Basin plain sediments show smaller mean-size $\phi$ values (coarser sediments) and less negatively skewed frequency curves (tail in the fine sediments) than the slope basin sediments. Sorting is variably distributed. These characteristics are derived from a limited number of sites, but with a very large number of samples, and reflect a trend from the slope to the abyssal plain that can be generalized for the entire depositional system of the Cascadia Basin.

Basin plain deposits, as well as slope basin deposits, are composed mainly of turbidites. Marginal ridges that successively accreted on the lower slope formed elongated sedimentary basins that were previously filled by time-transgressive turbiditic sequences of increasing thickness towards the east of the margin. During the Pleistocene, on the continental slope of the Washington Margin, about one-third of the total sediment supply from the continental shelf has been trapped within slope basins, while the remaining two-thirds have reached the Cascadia Basin (Barnard, 1978). That slope basins may act as sedimentary traps for turbidity current flows has already been proposed on several examples in the Mediterranean Sea by
Stanley and Maldonado (1981). Stanley and Maldonado proposed that the coarsest grain-size fraction of the flows was trapped in slope basins, while the finest fraction reached the abyssal plain to form uniform fine-grained mud beds called "unifites". Analogously, Barnard (1978) invoked bypassing of slope basins of the Washington Margin by the fine-grained sediments in the Holocene.

The tail in the coarser material (more negative skewness) observed in the curve of size distribution of the fine-grained sediment selected for our study, which includes the upper part of coarsegrained turbidites, could indicate that coarse-grained sediment trapping has occurred. This should result in poorly sorted deposits as well. Although all the sediment analyzed show moderate to poor sorting $(0.8<\sigma<1.7)$, we cannot detect any trend to higher sorting values in the slope basin samples.

We clearly lack unequivocal evidence to support sediment trapping in the slope basin as a sedimentary process. A transect of samples from slope to basin is needed to confirm this.

If we consider the facies change from middle to outer fan as a trend from proximal to distal deposition, the grain-size trends reverse and indicate fining and decreasing skewness towards distal deposition, in fair agreement with the findings of Stow (1979) on the finegrained turbidites of the Scotian Margin, which in turn confirm theoretical predictions of McCave and Swift (1976). Grain size frequency curves differ from the upper slope to the abyssal plain with a trend towards finer modes and poorer sorting (approximately linear correlation between sorting [standard deviation] and mean size) in the direction of sediment transport and deposition. However, downslope trends of sorting are opposite in silt laminae and muds (Stow, 1979; 


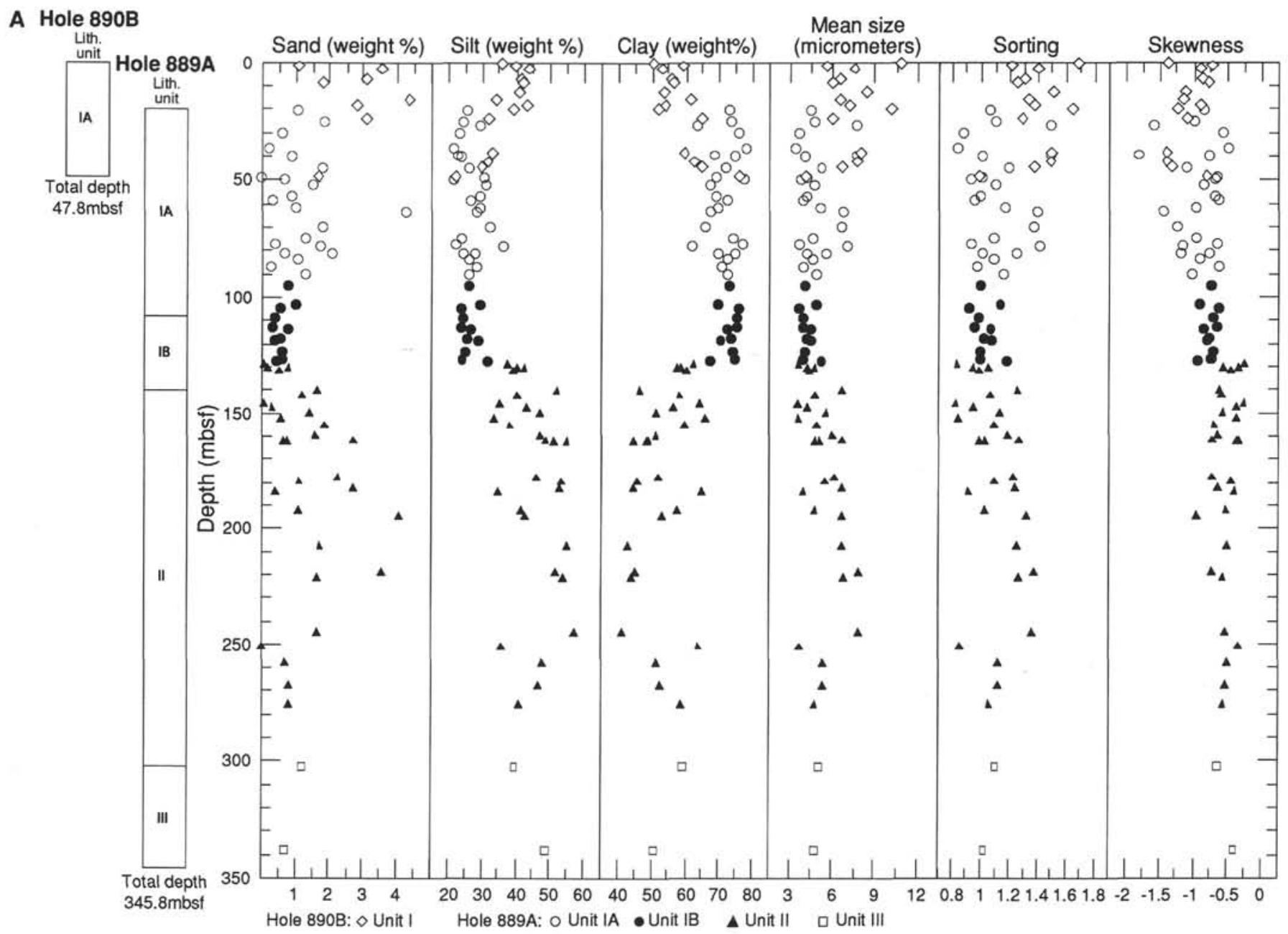

Figure 6. Downhole distribution of (A) grain size and statistical parameters and (B) silt classes distribution obtained with the SediGraph 5000ET and calibrated Lab-Tec analyses at Hole 890B. Different symbols refer to the units indicated in the graphic log on the left (after Shipboard Scientific Party, 1994b). See text for discussion.

Fig. 2).Varying proximal to distal trends in clay content of turbidites of the Astoria channel were related to different depositional processes by Nelson (1976). Pleistocene (glacial) turbidites sampled on the distal part of the fan are cleaner, have lower matrix and are comparably coarse-grained and thickly bedded than in the upper/middle fan. Holocene turbidites, although limited to the channel floor and to a low extent of interchannel area, display an opposite trend.

The mechanism proposed for the textural trend of Pleistocene turbidites is a progressive loss of fine material in the upper/middle fan due to spreading of the turbid flow over the sides of the channel to form levee and inter-channel deposits. Holocene turbidity current flows of the Astoria fan, smaller than those of the Pleistocene, are instead confined in the channels (see also Griggs and Kulm, 1970) and retain the fine components of the turbid cloud. Therefore, finegrained turbidites, or fine-grained tails of coarse-grained turbidites, may show different degrees of sorting depending on the extent of the loss of fine material occurring during channelized flow. This is controlled by a number of factors, including thickness of the turbidity current, depth of the channel with respect to the levees, and amount of fine-grained material in the original source area.

We than conclude that mean size and skewness of the fine fraction of sediments drilled on Leg 146 reflect the distal-proximal trends across the margin. The information provided by the sorting parameters appears to be biased by different depositional processes occurring during glacial and interglacial periods that have not been recognized from core description in the sedimentary record.

The relationship between skewness and mean grain size in the Cascadia Basin (fine sediments are more negatively skewed) and the trend of the mean size, which is larger in the abyssal plains than in the slope basins, coincides with a high-energy transport system as modeled by McLaren and Bowles (1985), and corresponds to the general direction of sediment transport from slope to the abyssal plains. In particular, coarsening in the direction of sediment transport is the typical characteristic of the Pleistocene (glacial) turbidites that built the deep sea fans of the Cascadia Basin. We speculate that the Holocene (interglacial) turbidites, which according to Nelson (1976) and Griggs and Kulm (1970) display opposite grain-size characteristics, belong to a low-energy transport system corresponding to decreasing mean size in the direction of transport. As discussed earlier, these low-energy turbidites are confined within channels and are not present in the outer part of the deep sea fans.

As suggested by McLaren and Bowles (1985), and shown in Stow (1979) sorting does not necessarily increases in the direction of sediment transport. In the Cascadia Basin, abyssal plain deposits are less 


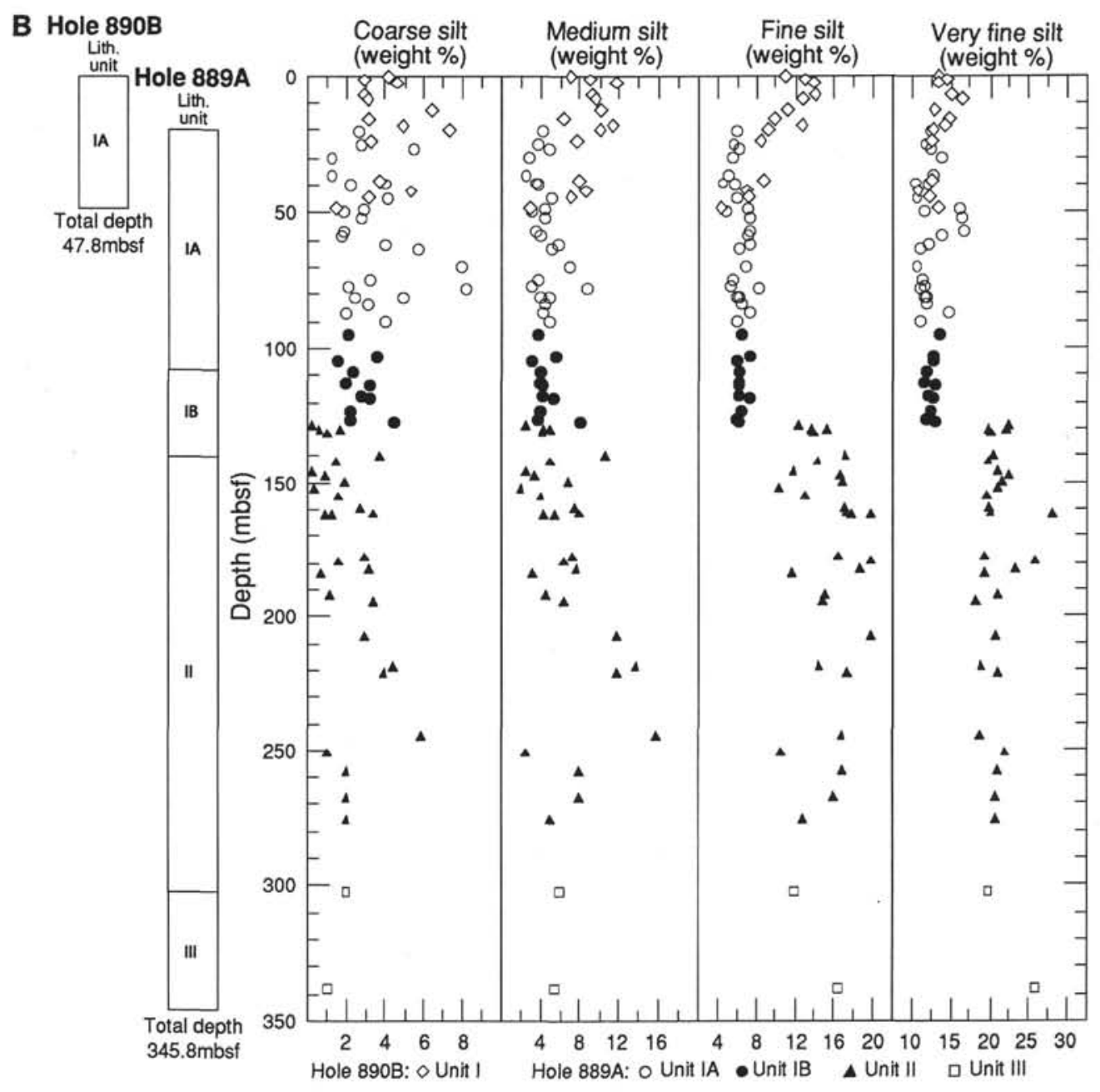

Figure 6 (continued).

sorted than slope basin deposits, because of the size sorting of the grains composing turbidity currents by trapping in successive slope basins.

The sorting vs. skewness relationship allows further discrimination between outer fan and middle fan deposits, for which the proximal to distal trends are reverted. Middle fan samples are coarser grained, positively skewed, and less well sorted than the outer fan samples. Apparently, this difference is due to the low energy of deposition of the turbid flow in the middle/outer part of the fan, resulting in particles becoming finer in the direction of transport (McLaren and Bowles, 1985).

\section{Sediment Composition and Grain Size}

We have collected evidence that variations in sediment composition do not affect the grain-size distribution in the Cascadia Basin. The present day sediment provenance suggests that local sediment provenance is more important than distal (Krissek, 1984). The main sediment provenance of the Nitinat and Astoria fans has been the British Columbia coastal range and the Columbia river drainage area respectively, although the composition of the Pleistocene fan sediments is typical of a glaciated drainage area that differs from the present day one. Grain size analysis has not provided the basis for a distinction between units deposited in the north (British Columbia drainage area) and in the south (Columbia River drainage area) of the Cascadia Basin. Correlation of units with analogous sedimentary en- vironment has been possible across the depositional systems (e.g., middle fan Site 888 Unit II and Site 891 Subunits IB and -C). Furthermore, correlation has been possible between lithostratigraphic units deposited before and after a change in sediment composition that occurred in the Pleistocene before the development of the Astoria fan. This consists of upward transition from an amphibole to an amphibole-pyroxene assemblage in the sands of the abyssal plain turbidites, and suggests a more northerly or southerly provenance at that time (Scheidegger et al., 1973). Lithostratigraphic units from the two sites of the Oregon Margin belong to abyssal plain sediments deposited before (Pliocene turbidites at Site 892) and after (Pleistocene turbidites at Site 891) the change in sediment composition and provenance, and plot in the same fields of the bivariate plots of grain-size parameters. Furthermore, Scheidegger et al. (1973) exclude that the composition change is a sorting effect of the change from silt abyssal plain turbidites below to sandy turbidites in the deep sea fan sequence above. Finally, petrographic analyses on sand and silt grains carried out during Leg 146 have not detected changes in sediment composition, and, in particular, no changes have been observed at the unit boundaries (Westbrook, Carson, Musgrave, et al., 1994).

\section{CONCLUSIONS}

With a data set of 442 samples, we have demonstrated that it is possible to calibrate grain-size analyses made by a Lab-Tec particle- 


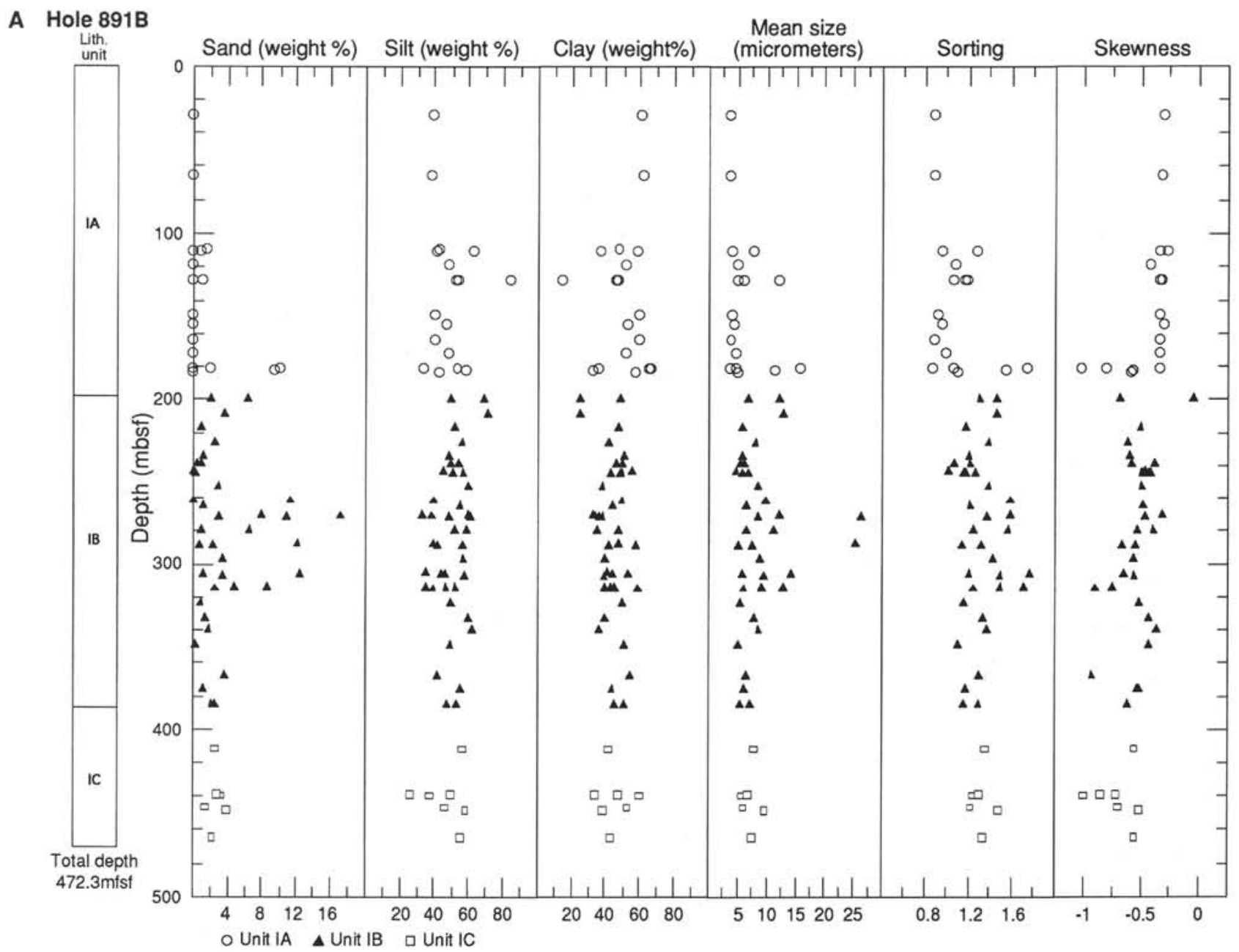

Figure 7. Downhole distribution of (A) grain size and statistical parameters and (B) silt classes distribution obtained with the SediGraph 5000ET and calibrated Lab-Tec analyses at Hole 891B. Different symbols refer to the units indicated in the graphic log on the left (after Shipboard Scientific Party, 1994c). See text for discussion.

size analyzer with results from a SediGraph 5000 ET particle sizer. Calibration between the two instruments allows fast shipboard analysis of a very large number of samples. The calibration of a limited number of samples with the SediGraph reduces to a minimum the time spent on post-cruise analytical work (our $225 \mathrm{Lab}-\mathrm{Tec}$ samples were calibrated with only 33 SediGraph analyses). The possibility of obtaining large numbers of grain-size analyses offers an opportunity to re-evaluate the environmental significance of statistical parameters.

Our grain-size study of Leg 146 showed that the most useful data are contained in the distribution of the silt-size classes, and the correlation between the two instruments also gives better results within the silts.

Bivariate plots of statistical parameters allow discrimination of lithostratigraphic units that confirms the original shipboard subdivision and the proposed environmental significance. We were able to distinguish, based on statistical parameters, between basin plain deposits (outer and middle fan) and slope basin deposits. In addition, slumped and reworked sediments could be distinguished on the same basis. The identification of the transition between basin plain and slope basin sediments within the record of Site 889 allows us to locate in the sedimentary sequence the tectonic uplift produced by accretionary processes.
Grain size trends along the direction of sediment transport have been identified and related to depositional processes. Skewness and mean size relations correspond to the general direction of sediment transport from slope to abyssal plain. Sorting does not necessarily increase in the direction of transport. The grain sorting vs. skewness relationship allows further discrimination between proximal mid-fan deposits and distal outer fan deposits.

Variations in source area and sediment composition do not affect the textural characteristics of sediments in the Cascadia Basin.

\section{ACKNOWLEDGMENTS}

We thank in particular Dave Gunn for assistance during the laboratory analyses and data processing and Phil Weaver for instructive discussion and helpful suggestions. Charlie Gravestock provided helpful assistance during the laboratory analyses at I.O.S. Rob Kidd kindly provided support and encouragement for the phase of data processing and plotting at Cardiff. The shipboard sedimentologists of Leg 146 assisted during the shipboard data analysis. We thank M. Underwood and an anonymous reviewer for the useful suggestions that improved the manuscript.

Funding for this post-cruise study was provided by CNR-ODP Italy. 


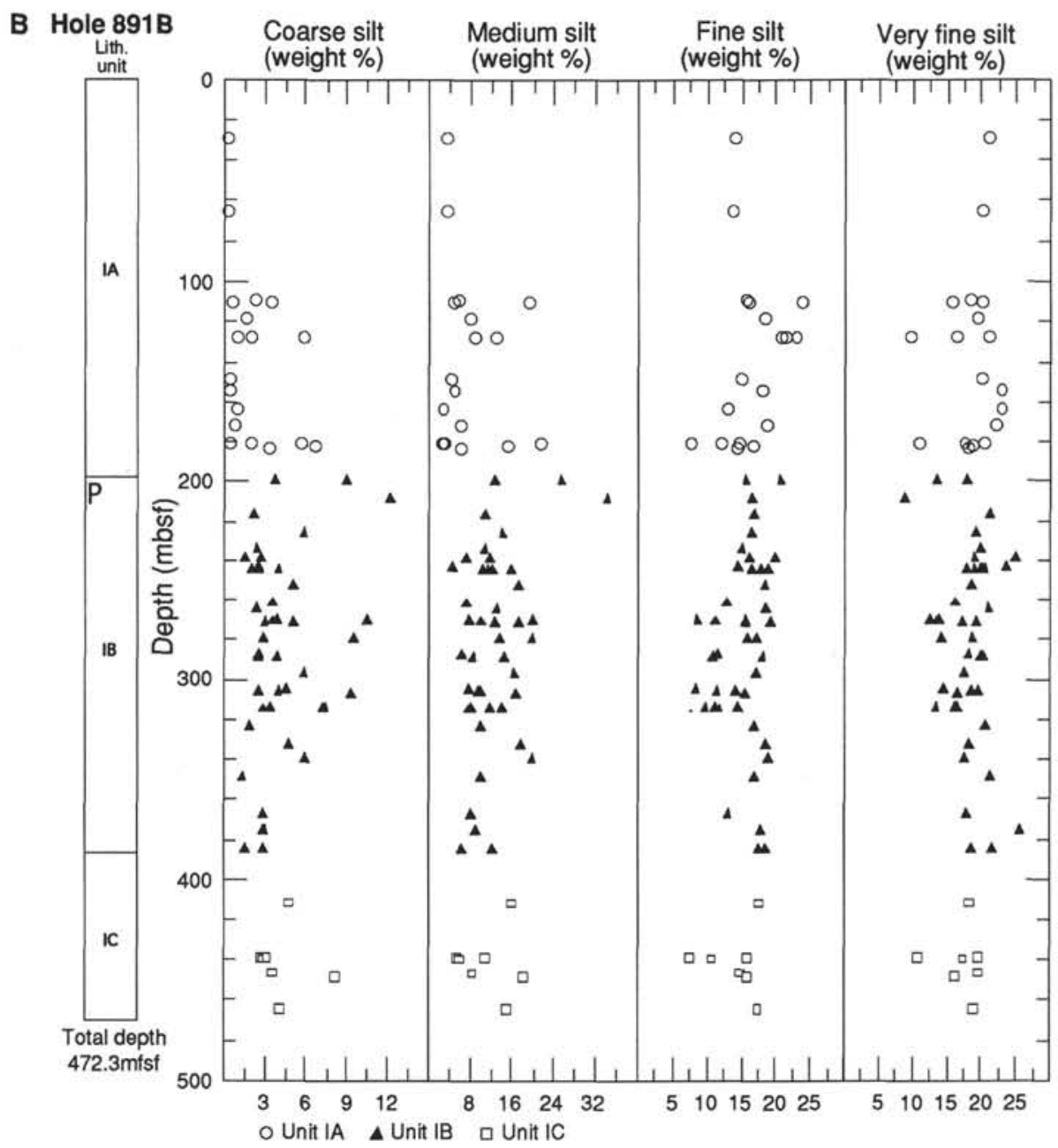

Figure 7 (continued).

\section{REFERENCES}

Antia, E.E., 1993. Surficial grain-size statistical parameters of the North Sea shoreface-connected ridge: patterns and process implication. Geo-Mar. Lett., 13:182-188.

Barnard, W.D., 1978. The Washington continental slope: Quaternary tectonics and sedimentation. Mar. Geol., 27:79-114.

Carlson, P.R., and Nelson, C.H., 1987. Marine geology and resource potential of Cascadia Basin. In Scholl, D.W., Grantz, A., and Vedder, J.G. (Eds.), Geology and Resource Potential of the Continental Margin of Western North America and Adjacent Ocean Basins-Beaufort Sea to Baja California. Circum.-Pac. Counc. Energy Miner. Res., Earth Sci. Ser., 6:523-535.

Gao, S., Collins, M.B., Lanckneus, J., de Moor, G., and van Lancker, V., 1994. Grain size trends associated with net sediment transport patterns: an example from the Belgian continental shelf. Mar. Geol., 171-185.

Griggs, G.H., and Kulm, L.D., 1970. Sedimentation in the Cascadia deep sea channel. Geol. Soc. Am. Bull., 81:1361-1384.

Janecek, T.R., 1993. Data report: High-resolution carbonate and bulk grainsize data for Sites 803-806 (0-2 Ma). In Berger, W.H., Kroenke, L.W., Mayer, L.A., et al., Proc. ODP, Sci. Results, 130: College Station, TX (Ocean Drilling Program), 761-773.

Jones, K.P.N., McCave, I.N., and Patel, P.D., 1988. A computer-interfaced sedigraph for modal size analysis of fine-grained sediment. Sedimentology, 35:163-172.

Jones, K.P.N., McCave, I.N. and Weaver, P.P.E., 1992. Textural and dispersal patterns of thick mud turbidites from the Madeira Abyssal Plain. Mar. Geol., 107:149-173.

Krissek, L.A., 1984. Continental source area contributions to fine-grained sediments on the Oregon and Washington continental slope. In Leggett, J.K. (Ed.), Trench-Forearc Geology: Sedimentation and Tectonics on
Modern and Ancient Active Plate Margins: Oxford (Blackwell Sci. Publ.), 363-375.

Kulm, L.D., von Huene, R., et al., 1973. Init. Repts. DSDP, 18: Washington (U.S. Govt. Printing Office).

Loizeau, J.L., Arbouille, D., Santiago, S., and Wernet, J.P., 1994. Evaluation of wide range laser diffraction grain size analyses for use with sediments. Sedimentology, 41:353-361.

Lucchi, R., and Camerlenghi, A., 1993. Upslope turbidite sedimentation on the southeastern flank of the Mediterranean Ridge. Boll. Oceanol. Teor. Appl., 11:3-25.

McCave, I.N., and Swift, S.A., 1976. A physical model for the rate of deposition of fine-grained sediments in the deep sea. Geol. Soc. Am. Bull., 87:541-546.

McLaren, P., and Bowels, D., 1985. The effect of sediment transport on grain size distribution. J. Sediment. Petrol., 55:457-470.

McManus, J., 1988. Grain size determination and interpretation. In Tucker, M. (Ed.), Techniques in Sedimentology: Oxford (Blackwell Sci. Publ.), 63-85.

Medina, R., Losada, M.A., Losada, I.J., and Vidal, C., 1994. Temporal and spatial relationship between sediment grain size and beach profile. Mar. Geol., 118:195-206.

Mutti, E., and Ricci Lucchi, F., 1972. Le torbiditi dell'Appennino settentrionale: introduzione all'analisi di facies. Mem. Soc. Geol. Ital., 11:161199.

Nelson, H., 1976. Late Pleistocene and Holocene depositional trends, processes and history of Astoria deep-sea fan, Northeast Pacific. Mar. Geol., 20:129-173.

Pettijohn, F.J., 1957. Sedimentary Rocks (2nd ed.): New York (Harper).

Reinemann, L., and Schemmer, H., 1993. Fine sediments grain-size analysis: a comparison of wet sieving and laser methods. Dtsch. Gewaesserk. Mitt., 37:27-30. 
A Hole 892D

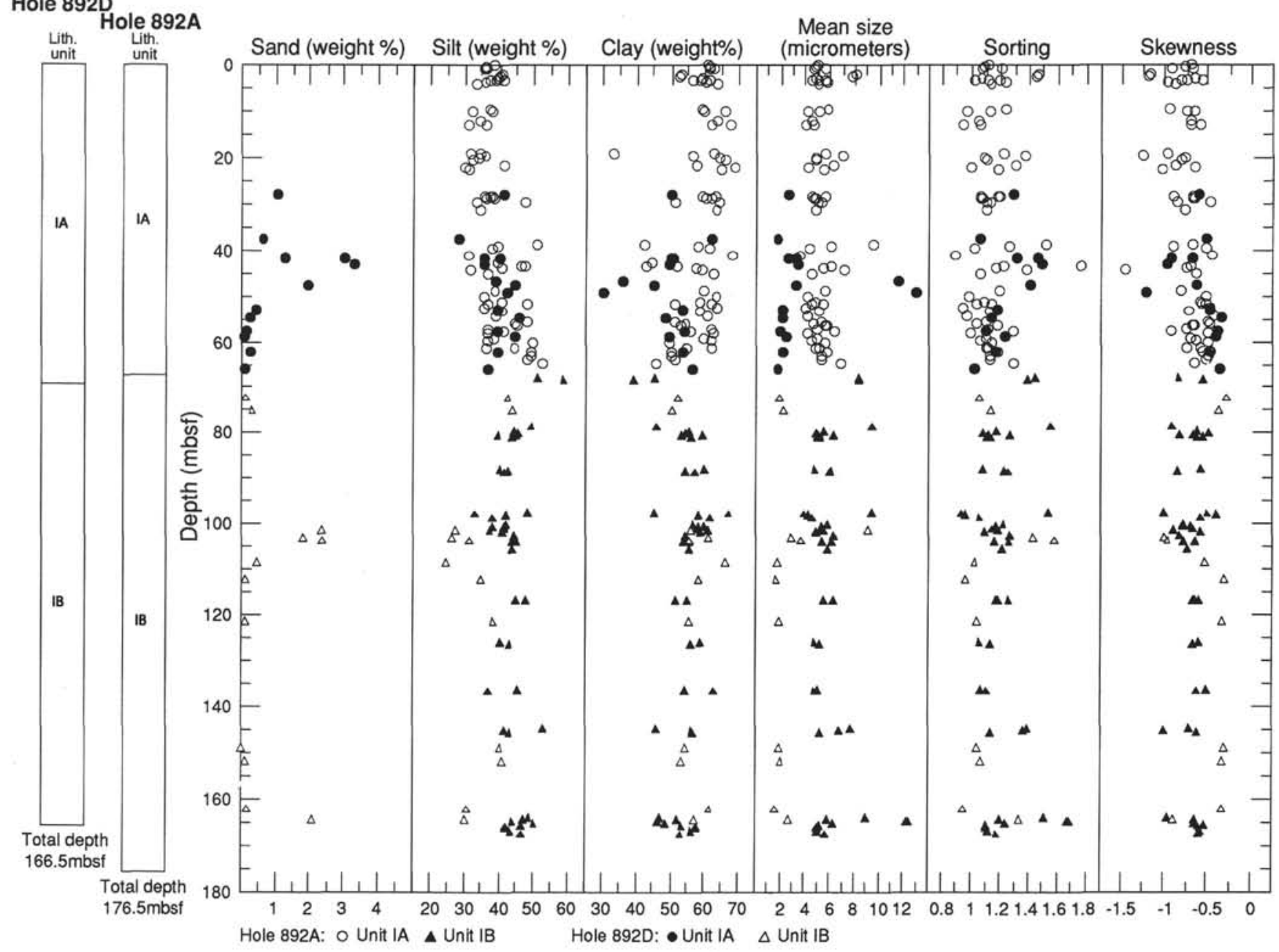

Figure 8. Downhole distribution of (A) grain size and statistical parameters and (B) silt classes distribution obtained with the SediGraph $5000 \mathrm{ET}$ and calibrated Lab-Tec analyses at Holes 892D and 892A. Different symbols refer to the units indicated in the graphic log on the left (after Shipboard Scientific Party, 1994d). See text for discussion.

Rothwell, R.G., Weaver, P.P.E., Hodkinson, R.A., Pratt, C.E., Styzen, M.J., and Higgs, N.C., 1994. Clayey nannofossil ooze turbidites and hemipelagites at Sites 834 and 835 (Lau Basin, southwest Pacific). In Hawkins, J., Parson, L., Allan, J., et al., Proc. ODP, Sci. Results, 135: College Station, TX (Ocean Drilling Program), 101-130.

Scheidegger, K.F., Kulm, L.D., and Piper, D.J.W., 1973. Heavy mineralogy of unconsolidated sands in northeastern Pacific sediments: Leg 18, Deep Sea Drilling Project. In Kulm, L.D., von Huene, R., et al., Init. Repts. DSDP, 18: Washington (U.S. Govt. Printing Office), 877-888.

Shipboard Scientific Party, 1994a. Site 888. In Westbrook, G.K., Carson, B., Musgrave, R.J., et al., Proc. ODP, Init. Repts., 146 (Pt. 1): College Station, TX (Ocean Drilling Program), 55-125.

, 1994b. Sites 889 and 890. In Westbrook, G.K., Carson, B., Musgrave, R.J., et al., Proc. ODP, Init. Repts., 146 (Pt. 1): College Station, TX (Ocean Drilling Program), 127-239.

, 1994c. Site 891. In Westbrook, G.K., Carson, B., Musgrave, R.J., et al., Proc. ODP, Init. Repts., 146 (Pt. 1): College Station, TX (Ocean Drilling Program), 241-300.

, 1994d. Site 892. In Westbrook, G.K., Carson, B., Musgrave, R.J., et al., Proc. ODP, Init. Repts., 146 (Pt. 1): College Station, TX (Ocean Drilling Program), 301-378.

Singer, J.K., Anderson, J.B., Ledbetter, M.T., McCave, I.N., Jones, K.P.N., and Wright, R., 1988. An assessment of analytical techniques for the size analysis of fine-grained sediments. J. Sediment. Petrol., 58:534-543.
Stanley, D.J. and Maldonado, A., 1981. Depositional models for the finegrained sediments in the Western Hellenic Trench, Eastern Mediterranean. Sedimentology, 28:273-290.

Stow, D.A.V., 1979. Distinguishing between fine-grained turbidites and contourites on the Nova Scotian deep water margin. Sedimentology, 26:371387.

Stow, D.A.V. and Wetzel A., 1990. Hemiturbidite: a new type of deep-water sediment. In Cochran, J.R., Stow, D.A.V., et al., Proc. ODP, Sci. Results, 116: College Station, TX (Ocean Drilling Program), 25-34.

Sutherland, R.A., and Lee C.-T., 1994. Discrimination between coastal subenvironments using textural characteristics. Sedimentology, 41:11331145.

Weedon, G.P., and McCave, I.N., 1991. Mud turbidites from the Oligocene and Miocene Indus Fan at Sites 722 and 731 on the Owen Ridge. In Prell, W.L., Niitsuma, N., et al., Proc. ODP, Sci. Results, 117: College Station, TX (Ocean Drilling Program), 215-220.

Wentworth, C.K., 1922. A scale of grade and class terms of clastic sediments. J. Geol., 30:377-392.

Westbrook, G.K., Carson, B., Musgrave, R.J., et al., 1994. Proc. ODP, Init. Repts., 146 (Pt. 1): College Station, TX (Ocean Drilling Program).

Date of initial receipt: 22 August 1994

Date of acceptance: 1 June 1995

Ms 146SR-202 


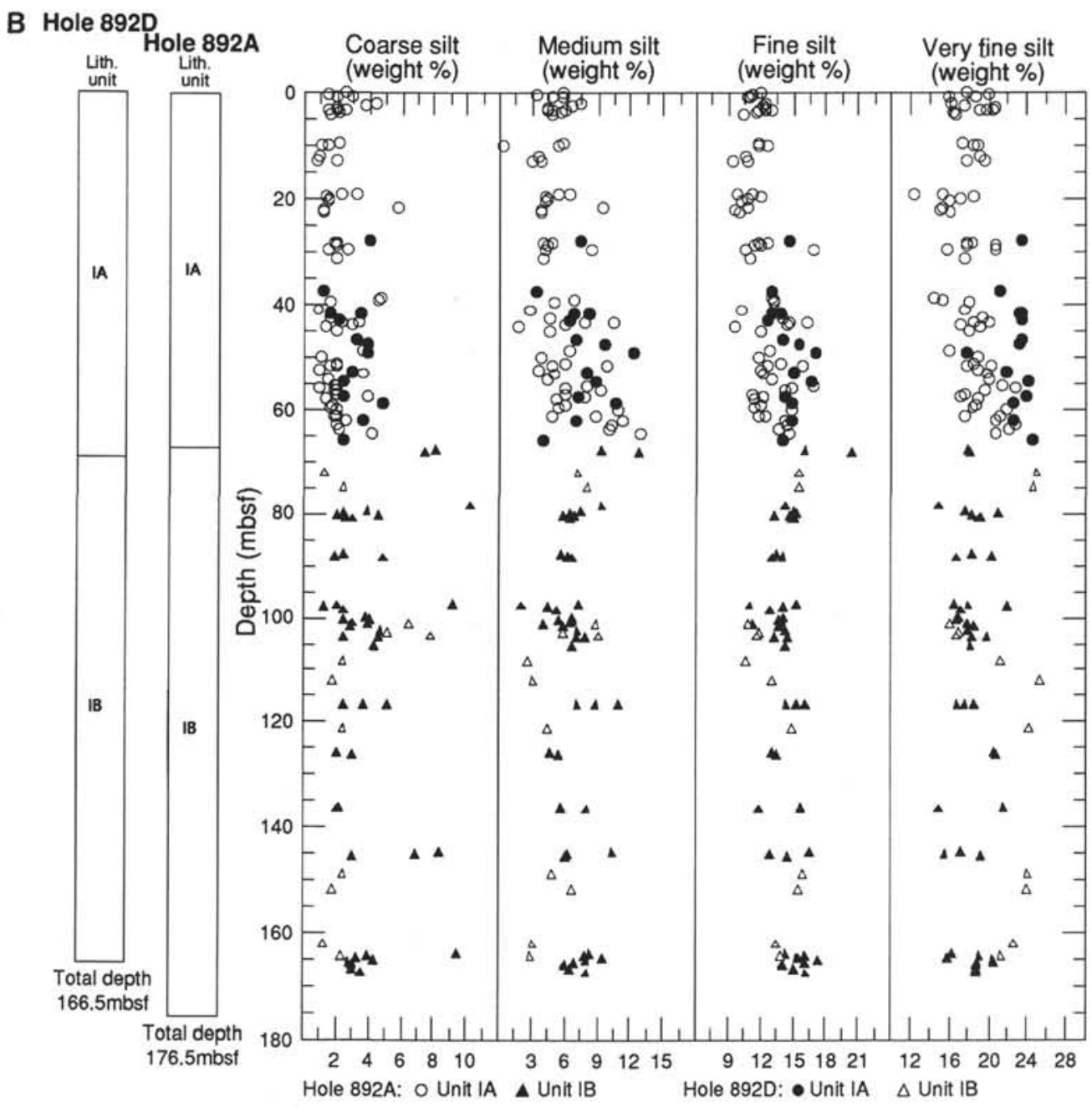

Figure 8 (continued). 


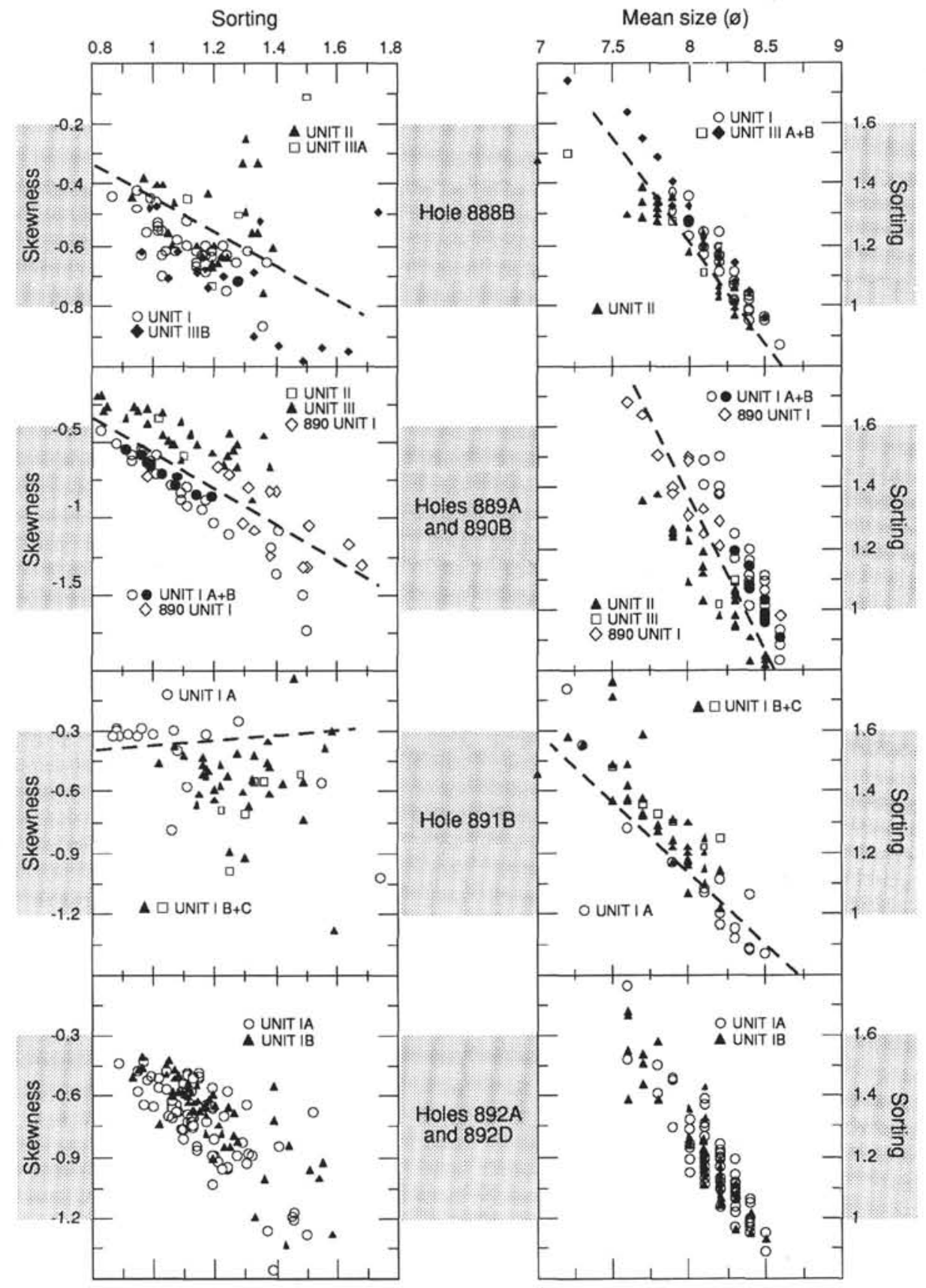

Figure 9. Bivariate plots of skewness vs. sorting and sorting vs. mean grain size for all sites. The units are designated after Westbrook, Carson, Musgrave, et al. (1994). The dashed lines mark the boundaries between two fields of occurrence of units. See text for discussion. 

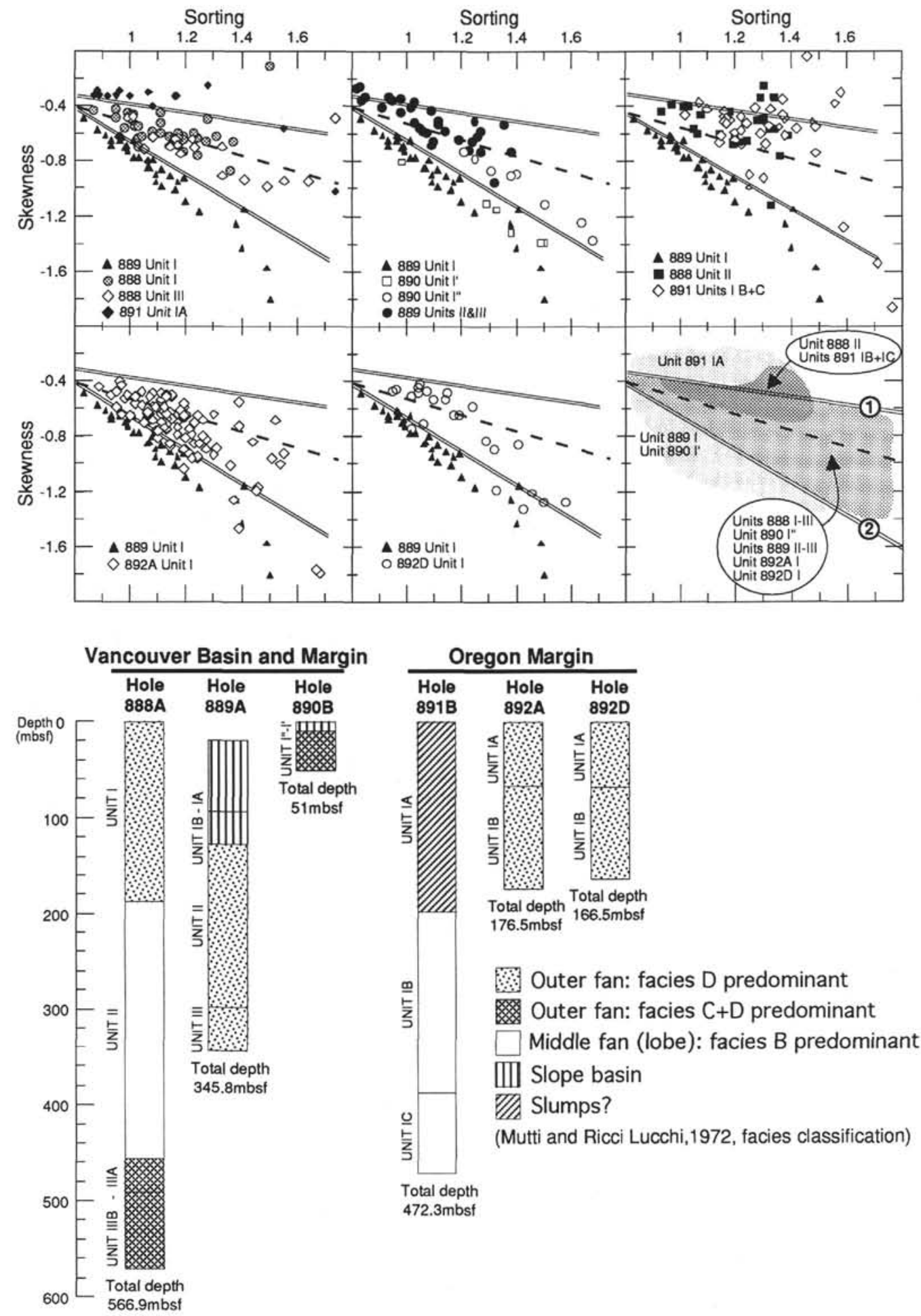

Figure 10. Comparison of bivariate plots of skewness vs. sorting for units from different Leg 146 sites. The units are designated after Westbrook, Carson, Musgrave, et al. (1994), except for Subunits I' and I" of Hole 890B, which were identified in this study. Lithostratigraphic units plot consistently in different fields separated by double lines (labeled as 1 and 2). The dashed lines indicate a subdivision within the intermediate field. The logs in the lower part of the figure combine the facies association with the distribution of units in the fields of the bivariate plots. See text for discussion. 

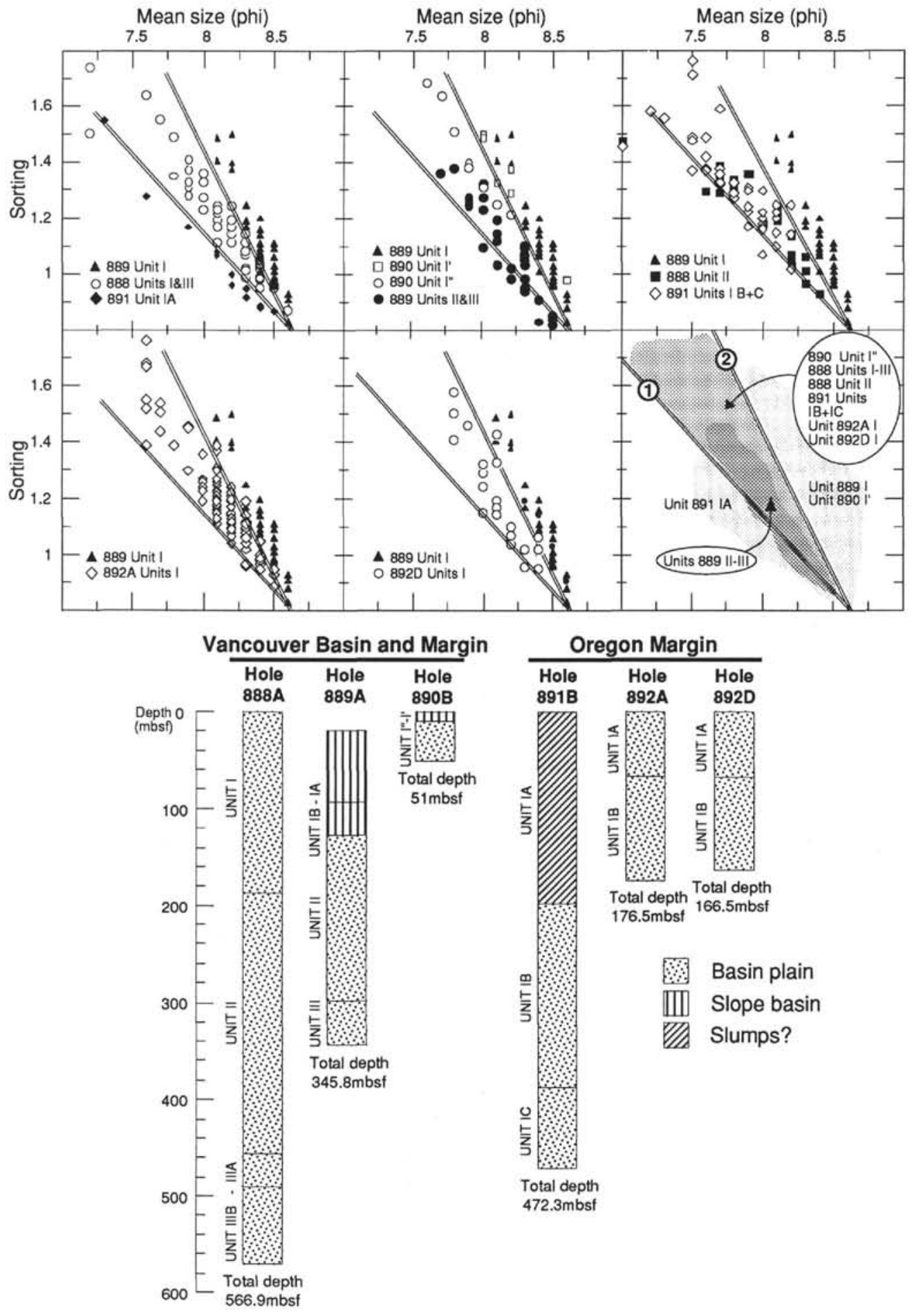

Figure 11. Comparison of bivariate plots of sorting vs. mean size for units from different Leg 146 sites. The units designated are after Westbrook, Carson, Musgrave, et al. (1994) except for Subunits I' and I" of Hole 890B, which were identified in this study. Lithostratigraphic units plot consistently in different fields separated by double lines (labeled as 1 and 2). The logs in the lower part of the figure combine the environment of deposition with the distribution of units in the fields of the bivariate plots. Note the results from skewness vs. sorting (previous figure) and the sorting vs. mean grain size (this figure) bivariate plots are substantially identical. See text for discussion. 

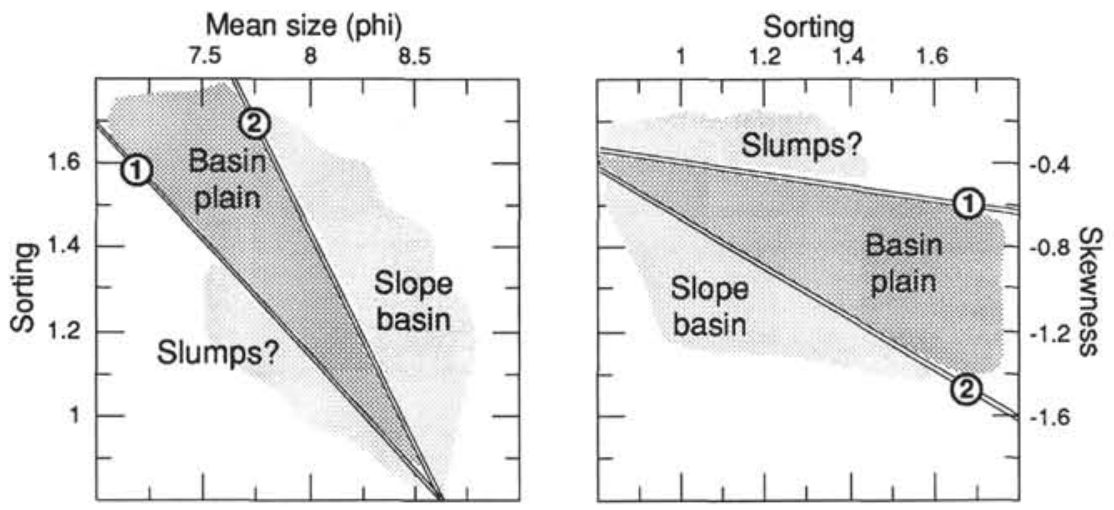

Figure 12. Syntheses of the suggested environmental significance of the bivariate plots of statistical parameters for the sediments drilled during Leg 146 on the Cascadia Margin. 
APPENDIX A

Grain-size Analyses by SediGraph 5000ET

\begin{tabular}{|c|c|c|c|c|c|c|c|c|c|c|c|c|c|c|c|}
\hline \multirow{2}{*}{$\begin{array}{l}\text { Core, section, } \\
\text { interval }(\mathrm{cm})\end{array}$} & \multirow{2}{*}{$\begin{array}{l}\text { Depth } \\
\text { (mbsf) }\end{array}$} & \multicolumn{9}{|c|}{ Grain size $(\phi)$} & \multicolumn{2}{|c|}{ Mean size } & \multirow[b]{2}{*}{ Sorting } & \multirow[b]{2}{*}{ Skewness } & \multirow{2}{*}{$\begin{array}{c}\text { Lithologic } \\
\text { unit }\end{array}$} \\
\hline & & $>8$ & 8 & 7 & 6 & 5 & 4 & 3 & 2 & 1 & $(\mu \mathrm{m})$ & $(\phi)$ & & & \\
\hline 146-888B- & & & & & & & & & & & & & & & \\
\hline $2 \mathrm{H}-1,58-60$ & 6.08 & 5.30 & 0.00 & 0.00 & 0.00 & 0.00 & 39.57 & 53.86 & 1.28 & 0.00 & 67.17 & 4.17 & 1.25 & 1.9 & \\
\hline $2 \mathrm{H}-3,59-61$ & 9.09 & 3.51 & 0.00 & 0.00 & 0.00 & 0.00 & 29.94 & 65.37 & 0.91 & 0.27 & 73.28 & 3.98 & 1.07 & 1.4 & \\
\hline $2 \mathrm{H}-6,69-71$ & 13.69 & 57.00 & 18.00 & 13.50 & 9.50 & 2.00 & 0.00 & 0.00 & 0.00 & 0.00 & 5.00 & 8.19 & 1.11 & -0.5 & \\
\hline $3 \mathrm{H}-4,58-60$ & 20.08 & 3.26 & 0.00 & 0.00 & 0.00 & 0.00 & 7.41 & 17.69 & 35.96 & 35.69 & 202.10 & 2.68 & 1.47 & -246.0 & \\
\hline $5 \mathrm{H}-2,14-16$ & 35.64 & 73.50 & 13.50 & 6.50 & 4.00 & 2.50 & 0.00 & 0.00 & 0.00 & 0.00 & 3.90 & 8.52 & 0.96 & -0.6 & \\
\hline $5 \mathrm{H}-2,15^{*}$ & 35.65 & 79.50 & 12.50 & 5.00 & 1.50 & 1.50 & 0.00 & 0.00 & 0.00 & 0.00 & 3.17 & 8.67 & 0.77 & -0.4 & \\
\hline $5 \mathrm{H}-2,102-104$ & 36.52 & 11.38 & 3.09 & 2.85 & 4.58 & 2.85 & 28.57 & 45.74 & 0.94 & 0.00 & 56.66 & 4.80 & 1.84 & 2.91 & \\
\hline $5 \mathrm{H}-4,140-142$ & 39.90 & 65.00 & 15.00 & 10.50 & 7.00 & 2.50 & 0.00 & 0.00 & 0.00 & 0.00 & 4.57 & 8.33 & 1.07 & -0.6 & \\
\hline $5 \mathrm{H}-5,137-139$ & 41.37 & 64.90 & 15.98 & 10.98 & 6.49 & 1.50 & 0.15 & 0.00 & 0.00 & 0.00 & 4.32 & 8.36 & 1.02 & -0.54 & \\
\hline $6 \mathrm{H}-6,40-46$ & 51.40 & 6.96 & 1.66 & 2.98 & 20.54 & 33.47 & 29.90 & 2.31 & 2.18 & 0.00 & 33.07 & 5.35 & 1.31 & 1.00 & \\
\hline $7 \mathrm{H}-2,127-130$ & 55.77 & 1.34 & 0.00 & 0.00 & 0.00 & 0.00 & 4.54 & 27.37 & 65.95 & 0.80 & 145.53 & 2.94 & 0.91 & 1.04 & \\
\hline $7 \mathrm{H}-5,107-109$ & 60.09 & 6.86 & 0.00 & 0.00 & 0.00 & 0.00 & 31.53 & 59.16 & 2.44 & 0.00 & 70.40 & 4.17 & 1.40 & 2.49 & \\
\hline $8 \mathrm{H}-1,99-101$ & 63.49 & 69.00 & 16.00 & 7.50 & 4.00 & 3.50 & 0.00 & 0.00 & 0.00 & 0.00 & 4.30 & 8.43 & 1.03 & -0.70 & \\
\hline $8 \mathrm{H}-1,68-70$ & 67.70 & 9.83 & 0.00 & 0.00 & 0.00 & 0.00 & 8.24 & 39.39 & 41.88 & 0.66 & 114.82 & 3.69 & 1.86 & 4.67 & \\
\hline $9 \mathrm{H}-1,110-112$ & 73.10 & 4.46 & 0.00 & 0.00 & 0.00 & 0.00 & 4.55 & 24.87 & 63.64 & 2.50 & 144.97 & 3.10 & 1.40 & 2.83 & \\
\hline $9 \mathrm{H}-4,85-87$ & 77.37 & 58.50 & 14.50 & 12.50 & 11.50 & 3.00 & 0.00 & 0.00 & 0.00 & 0.00 & 5.43 & 8.14 & 1.19 & -0.62 & \\
\hline $9 \mathrm{H}-6,13-16$ & 79.65 & 3.72 & 1.24 & 1.14 & 2.22 & 1.96 & 64.27 & 24.12 & 1.32 & 0.00 & 53.02 & 4.51 & 1.15 & 1.26 & \\
\hline $10 \mathrm{H}-3,60-62$ & 85.12 & 4.24 & 1.51 & 1.36 & 7.57 & 14.98 & 59.75 & 8.14 & 2.46 & 0.00 & 43.88 & 4.84 & 1.18 & 1.09 & \\
\hline $10 \mathrm{H}-6,33-35$ & 89.37 & 61.50 & 19.00 & 12.50 & 4.50 & 2.50 & 0.00 & 0.00 & 0.00 & 0.00 & 4.42 & 8.33 & 1.02 & -0.53 & I \\
\hline $11 \mathrm{H}-4,66-68$ & 96.10 & 59.09 & 15.89 & 12.91 & 8.44 & 2.98 & 0.69 & 0.00 & 0.00 & 0.00 & 5.35 & 8.18 & 1.17 & -0.69 & \\
\hline $11 \mathrm{H}-5,89-91$ & 97.79 & 9.31 & 3.26 & 6.05 & 34.43 & 38.16 & 8.80 & 0.00 & 0.00 & 0.00 & 21.86 & 5.89 & 1.26 & 0.89 & \\
\hline $14 \mathrm{H}-2,76-78$ & 120.36 & 61.40 & 14.48 & 12.48 & 8.99 & 2.50 & 0.16 & 0.00 & 0.00 & 0.00 & 5.01 & 8.23 & 1.14 & -0.62 & \\
\hline $14 \mathrm{H}-3,82-84$ & 121.92 & 58.82 & 13.46 & 14.95 & 9.97 & 2.49 & 0.31 & 0.00 & 0.00 & 0.00 & 5.33 & 8.15 & 1.17 & -0.60 & \\
\hline $15 \mathrm{H}-3,15-19$ & 130.75 & 87.00 & 7.50 & 1.20 & 1.80 & 2.50 & 0.00 & 0.00 & 0.00 & 0.00 & 3.18 & 8.75 & 0.79 & -0.59 & \\
\hline $16 \mathrm{H}-2,91-93$ & 139.51 & 69.87 & 12.98 & 8.98 & 5.99 & 2.00 & 0.18 & 0.00 & 0.00 & 0.00 & 4.24 & 8.42 & 1.03 & -0.63 & \\
\hline $16 \mathrm{H}-4,72-74$ & 142.34 & 14.73 & 4.57 & 6.09 & 15.23 & 9.65 & 33.87 & 12.76 & 3.10 & 0.00 & 37.93 & 5.56 & 1.85 & 1.47 & \\
\hline $17 \mathrm{H}-1,63-65$ & 147.23 & 54.12 & 14.76 & 12.30 & 11.32 & 5.41 & 2.09 & 0.00 & 0.00 & 0.00 & 6.98 & 7.96 & 1.36 & -0.87 & \\
\hline $17 \mathrm{H}-2,106-108$ & 149.18 & 21.21 & 7.40 & 9.86 & 41.43 & 17.76 & 2.35 & 0.00 & 0.00 & 0.00 & 14.48 & 6.67 & 1.44 & 0.56 & \\
\hline $17 \mathrm{H}-4,30^{*}$ & 151.40 & $\begin{array}{l}21.69 \\
51.69\end{array}$ & 14.91 & 12.92 & 15.91 & 3.98 & 0.59 & 0.00 & 0.00 & 0.00 & 6.60 & 7.93 & 1.31 & -0.62 & \\
\hline $18 \times-4,90^{*}$ & 161.50 & 59.62 & 16.89 & 11.92 & 8.45 & 2.48 & 0.63 & 0.00 & 0.00 & 0.00 & 5.15 & 8.21 & 1.14 & -0.66 & \\
\hline $18 X-4,98-100$ & 161.58 & 65.50 & 16.00 & 11.00 & 4.50 & 3.00 & 0.00 & 0.00 & 0.00 & 0.00 & 4.42 & 8.37 & 1.04 & -0.62 & \\
\hline $18 X-4,105-107$ & 161.65 & 8.76 & 3.41 & 6.33 & 47.23 & 30.67 & 3.60 & 0.00 & 0.00 & 0.00 & 19.26 & 6.03 & 1.17 & 0.71 & \\
\hline $19 \mathrm{X}-2,70^{*}$ & 167.80 & 54.43 & 14.84 & 14.84 & 12.86 & 1.98 & 1.04 & 0.00 & 0.00 & 0.00 & 5.90 & 8.04 & 1.23 & -0.60 & \\
\hline $19 X-3,11-13$ & 168.73 & 15.24 & 5.90 & 6.88 & 43.26 & 27.03 & 1.69 & 0.00 & 0.00 & 0.00 & 16.94 & 6.35 & 1.37 & 0.78 & \\
\hline $19 X-3,88-90$ & 169.50 & 67.41 & 16.48 & 9.49 & 4.49 & 2.00 & 0.14 & 0.00 & 0.00 & 0.00 & 4.11 & 8.42 & 0.98 & -0.56 & \\
\hline $21 \mathrm{X}-1,39-41$ & 184.99 & 34.24 & 10.35 & 7.17 & 13.93 & 13.14 & 12.82 & 5.35 & 3.00 & 0.00 & 23.56 & 6.74 & 2.03 & -0.73 & \\
\hline $24 X-3,114-116$ & 217.04 & 9.73 & 0.00 & 0.00 & 0.00 & 0.00 & 28.02 & 35.72 & 22.59 & 3.94 & 97.14 & 4.01 & 1.83 & 0.54 & $\mathrm{Tr}$ \\
\hline $25 \mathrm{H}-3,80-82$ & 221.20 & 6.21 & 0.00 & 0.00 & 0.00 & 0.00 & 36.05 & 45.41 & 12.07 & 0.26 & 78.19 & 4.08 & 1.43 & 2.29 & \\
\hline $26 \mathrm{H}-1,141^{*}$ & 228.31 & 58.34 & 14.83 & 13.84 & 9.89 & 1.98 & 1.11 & 0.00 & 0.00 & 0.00 & 5.47 & 8.15 & 1.19 & -0.66 & \\
\hline $26 \mathrm{H}-1,147-149$ & 228.37 & 58.63 & 13.91 & 12.92 & 11.43 & 2.48 & 0.62 & 0.00 & 0.00 & 0.00 & 5.55 & 8.13 & 1.21 & -0.66 & \\
\hline $27 \mathrm{H}-6,59-62$ & 242.29 & 4.34 & 0.00 & 0.00 & 0.00 & 0.00 & 24.27 & 46.04 & 24.46 & 0.89 & 97.56 & 3.72 & 1.34 & 1.99 & \\
\hline $29 \mathrm{H}-6,87-90$ & 260.17 & 0.32 & 0.14 & 0.22 & 1.40 & 4.88 & 27.63 & 47.47 & 17.55 & 0.38 & 88.05 & 3.73 & 0.87 & 0.23 & \\
\hline $30 \mathrm{H}-3,57-59$ & 264.37 & 1.22 & 0.27 & 0.24 & 0.54 & 0.54 & 6.51 & 56.97 & 33.59 & 0.12 & 113.16 & 3.34 & 0.94 & 0.88 & \\
\hline $31 \mathrm{H}-3,71-73$ & 271.55 & 3.73 & 0.00 & 0.00 & 0.00 & 0.00 & 6.66 & 42.14 & 41.63 & 5.84 & 133.35 & 3.24 & 1.33 & -1.12 & \\
\hline $32 \mathrm{H}-\mathrm{CC}, 7-9$ & 279.14 & 14.69 & 3.30 & 3.60 & 5.10 & 3.15 & 8.22 & 36.62 & 21.18 & 4.16 & 89.74 & 4.54 & 2.30 & -2.50 & \\
\hline $33 \mathrm{H}-1,42^{*}$ & 283.22 & 28.26 & 9.74 & 13.64 & 34.10 & 11.69 & 2.56 & 0.00 & 0.00 & 0.00 & 12.08 & 7.02 & 1.48 & 0.18 & \\
\hline $33 \mathrm{H}-4,68-70$ & 285.97 & 4.46 & 1.70 & 1.83 & 7.21 & 10.48 & 17.81 & 24.61 & 23.38 & 8.52 & 104.09 & 4.00 & 1.76 & -29.77 & \\
\hline $34 \mathrm{H}-3,33-35$ & 295.65 & 4.21 & 0.00 & 0.00 & 0.00 & 0.00 & 11.90 & 45.70 & 34.72 & 3.47 & 118.61 & 3.43 & 1.37 & 1.37 & \\
\hline $35 \mathrm{H}-1,84-86$ & 301.34 & 1.78 & 1.00 & 1.17 & 2.30 & 2.35 & 27.52 & 48.99 & 13.86 & 1.02 & 84.43 & 3.89 & 1.18 & 1.06 & \\
\hline $36 \mathrm{H}-1,13-15$ & 310.13 & 15.99 & 6.20 & 8.49 & 19.58 & 14.69 & 14.19 & 17.18 & 3.69 & 0.00 & 36.72 & 5.77 & 1.93 & 0.86 & II \\
\hline $36 \mathrm{H}-6,38-40$ & 316.11 & 61.09 & 18.38 & 12.42 & 5.46 & 1.99 & 0.67 & 0.00 & 0.00 & 0.00 & 4.67 & 8.29 & 1.06 & -0.60 & \\
\hline $37 \mathrm{H}-\mathrm{CC}, 18-20$ & 320.44 & 2.61 & 0.85 & 0.76 & 1.05 & 0.40 & 1.30 & 7.21 & 84.34 & 1.49 & 161.61 & 2.88 & 1.29 & 2.65 & \\
\hline $40 \mathrm{H}-1,25-28$ & 348.25 & 46.93 & 19.97 & 17.97 & 12.48 & 2.50 & 0.16 & 0.00 & 0.00 & 0.00 & 5.91 & 7.96 & 1.18 & -0.43 & \\
\hline $40 \mathrm{H}-6,58-62$ & 355.12 & 2.51 & 0.63 & 0.46 & 0.46 & 0.15 & 5.49 & 38.92 & 49.62 & 1.75 & 130.57 & 3.22 & 1.23 & 1.86 & \\
\hline $41 X-1,38-41$ & 357.38 & 1.88 & 0.54 & 0.73 & 1.84 & 2.61 & 34.64 & 56.10 & 1.61 & 0.06 & 68.88 & 4.07 & 0.99 & 0.93 & \\
\hline $44 \mathrm{X}-2,133-136$ & 388.33 & 43.97 & 17.59 & 13.68 & 17.10 & 5.37 & 2.28 & 0.00 & 0.00 & 0.00 & 7.97 & 7.72 & 1.39 & -0.61 & \\
\hline $44 X-3,60-63$ & 389.10 & 47.58 & 15.86 & 14.87 & 16.85 & 3.47 & 1.36 & 0.00 & 0.00 & 0.00 & 7.03 & 7.84 & 1.32 & -0.56 & \\
\hline $44 X-3,143-145$ & 389.93 & 12.30 & 4.64 & 4.84 & 9.48 & 8.67 & 33.75 & 19.84 & 6.08 & 0.38 & 49.33 & 5.19 & 1.90 & 1.96 & \\
\hline $44 X-4,59-61$ & 390.59 & 56.38 & 22.45 & 13.97 & 4.49 & 1.50 & 1.21 & 0.00 & 0.00 & 0.00 & 4.79 & 8.25 & 1.05 & -0.56 & \\
\hline $44 X-4,66 *$ & 390.66 & 54.00 & 21.00 & 17.00 & 6.50 & 1.50 & 0.00 & 0.00 & 0.00 & 0.00 & 4.70 & 8.20 & 1.03 & -0.40 & \\
\hline $44 \mathrm{X}-6,25-27$ & 393.25 & 16.06 & 6.22 & 6.73 & 12.95 & 9.58 & 32.17 & 14.91 & 1.38 & 0.00 & 35.80 & 5.67 & 1.89 & 1.44 & \\
\hline $45 \mathrm{X}-1,61-64$ & 395.61 & 66.00 & 18.00 & 11.00 & 3.50 & 1.50 & 0.00 & 0.00 & 0.00 & 0.00 & 3.89 & 8.44 & 0.93 & -0.44 & \\
\hline $45 \mathrm{X}-1,129-131$ & 396.29 & 15.50 & 5.91 & 9.23 & 23.26 & 19.20 & 24.45 & 1.48 & 0.98 & 0.00 & 24.63 & 6.05 & 1.64 & 0.91 & \\
\hline
\end{tabular}


APPENDIX A (continued).

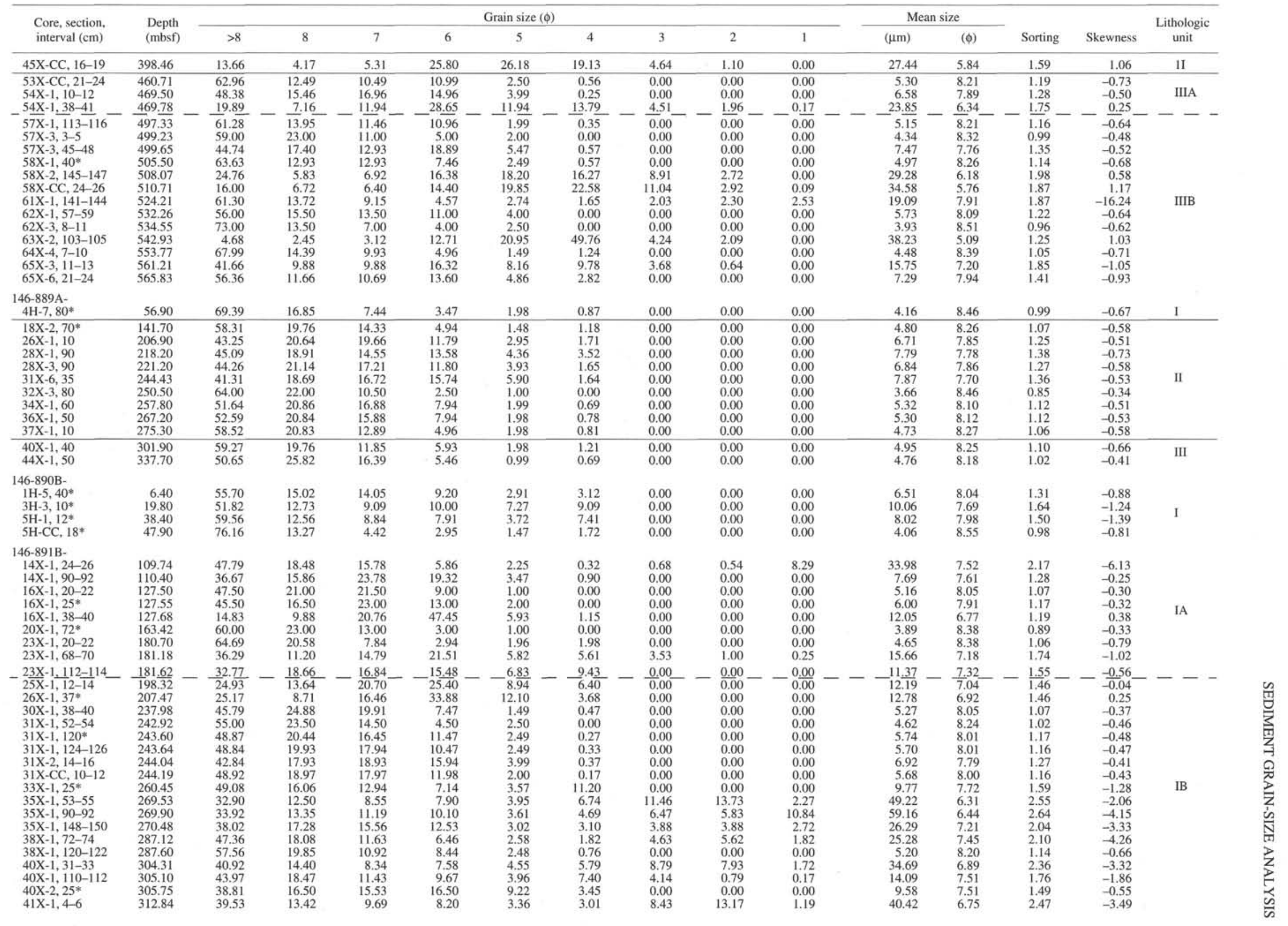




\begin{tabular}{|c|c|c|c|c|c|c|c|c|c|c|c|c|c|c|c|c|}
\hline \multirow{2}{*}{$\begin{array}{l}\text { Core, section, } \\
\text { interval }(\mathrm{cm})\end{array}$} & \multirow{2}{*}{$\begin{array}{l}\text { Depth } \\
\text { (mbsf) }\end{array}$} & \multicolumn{10}{|c|}{ Grain size $(\phi)$} & \multicolumn{2}{|c|}{ Mean size } & \multirow[b]{2}{*}{ Sorting } & \multirow[b]{2}{*}{ Skewness } & \multirow{2}{*}{$\begin{array}{c}\text { Lithologic } \\
\text { unit }\end{array}$} \\
\hline & & $>8$ & 8 & 7 & 6 & 5 & 4 & 3 & 2 & 1 & & $(\mu \mathrm{m})$ & ( $\phi)$ & & & \\
\hline $41 X-1,68-70$ & 313.48 & 44.75 & 16.44 & 10.96 & 11.87 & 7.31 & 5.02 & 2.87 & 0.62 & 0.16 & & 12.87 & 7.53 & 1.71 & -1.54 & \\
\hline $41 X-1,106-108$ & 313.86 & 58.50 & 16.58 & 11.70 & 7.80 & 2.93 & 2.50 & 0.00 & 0.00 & 0.00 & & 5.95 & 8.14 & 1.25 & -0.89 & IB \\
\hline $47 X-1,12-14$ & 366.22 & 54.48 & 17.84 & 13.02 & 8.20 & 2.89 & 3.57 & 0.00 & 0.00 & 0.00 & & 6.55 & 8.04 & 1.30 & -0.92 & $1 \mathrm{~B}$ \\
\hline $48 \mathrm{X}-1,20^{*}-$ & 375.20 & 43.49 & 25.70 & 17.79 & 8.90 & -2.97 & 1.16 & 0.00 & 0.00 & 0.00 & & 6.08 & 7.95 & 1.17 & -0.51 & \\
\hline $49 \bar{X}-1,0-3$ & $383 . \overline{90}$ & $50 . \overline{88}$ & 21.53 & 17.61 & 6.36 & $1 . \overline{47}$ & 2.15 & 0.00 & $\overline{0.00}$ & 0.00 & & $5 . \overline{62}$ & 8.09 & 1.15 & -0.61 & \\
\hline $49 \mathrm{X}-1,30-32$ & 384.20 & $\begin{array}{l}45.09 \\
2305\end{array}$ & 18.63 & 18.63 & 12.25 & 2.94 & 2.46 & 0.00 & 0.00 & 0.00 & & 6.99 & 7.85 & 1.29 & -0.60 & \\
\hline $55 \mathrm{X}-2,93-95$ & 438.60 & 33.95 & 10.91 & 7.28 & 5.46 & 2.73 & 10.81 & 23.17 & 5.38 & 0.31 & & 39.09 & 6.34 & 2.43 & -0.84 & IC \\
\hline $55 X-2,121-123$ & 438.88 & 60.00 & 17.42 & 10.65 & 5.81 & 2.90 & 3.22 & 0.00 & 0.00 & 0.00 & & 5.93 & 8.18 & 1.25 & -0.99 & \\
\hline $56 \mathrm{X}-1,13-15$ & 445.93 & 52.25 & 19.72 & 14.79 & 8.38 & 3.45 & 1.42 & 0.00 & 0.00 & 0.00 & & 5.97 & 8.05 & 1.22 & -0.69 & \\
\hline \multicolumn{17}{|l|}{ 146-892A- } \\
\hline $1 \mathrm{X}-1,49-51$ & 0.49 & 61.57 & 20.03 & 11.24 & 3.42 & 1.47 & 2.27 & 0.00 & 0.00 & 0.00 & & 4.88 & 8.31 & 1.09 & -0.76 & \\
\hline $1 X-1,89-91$ & 0.89 & 62.26 & 18.78 & 10.87 & 4.94 & 1.98 & 1.17 & 0.00 & 0.00 & 0.00 & & 4.72 & 8.31 & 1.07 & -0.68 & \\
\hline $1 X-3,19-21$ & 3.16 & 59.28 & 20.75 & 12.35 & 4.45 & 1.98 & 1.20 & 0.00 & 0.00 & 0.00 & & 4.79 & 8.28 & 1.07 & -0.64 & \\
\hline $1 X-3,46-48$ & 3.43 & 61.51 & 19.35 & 12.40 & 4.46 & 1.49 & 0.79 & 0.00 & 0.00 & 0.00 & & 4.46 & 8.33 & 1.02 & -0.56 & \\
\hline $1 X-4,5^{*}$ & 3.59 & 58.83 & 20.59 & 11.77 & 4.90 & 1.96 & 1.94 & 0.00 & 0.00 & 0.00 & & 5.12 & 8.25 & 1.12 & -0.74 & \\
\hline $2 \mathrm{X}-1,50^{*}$ & 10.00 & 59.66 & 18.58 & 12.71 & 5.38 & 1.47 & 2.20 & 0.00 & 0.00 & 0.00 & & 5.17 & 8.24 & 1.13 & -0.75 & \\
\hline $2 \mathrm{X}-3,58-61$ & 13.08 & 62.14 & 19.73 & 10.85 & 3.95 & 1.97 & 1.37 & 0.00 & 0.00 & 0.00 & & 4.69 & 8.33 & 1.06 & -0.69 & \\
\hline $3 \mathrm{X}-1,23-25$ & 19.23 & 33.35 & 12.43 & 9.81 & 6.54 & 3.27 & 5.70 & 15.61 & 11.39 & 1.90 & & 46.72 & 6.35 & 2.53 & -2.01 & \\
\hline $3 X-1,76-78$ & 19.76 & 56.47 & 18.52 & 12.03 & 4.17 & 1.39 & 7.42 & 0.00 & 0.00 & 0.00 & & 7.14 & 8.06 & 1.37 & -1.26 & \\
\hline $4 X-1,5^{*}$ & 28.55 & 59.07 & 18.40 & 12.59 & 4.84 & 1.94 & 3.16 & 0.00 & 0.00 & 0.00 & & 5.63 & 8.20 & 1.20 & -0.89 & \\
\hline $4 X-1.10$ & 28.60 & 63.27 & 17.79 & 11.86 & 3.95 & 1.98 & 1.14 & 0.00 & 0.00 & 0.00 & & 4.62 & 8.34 & 1.06 & -0.66 & \\
\hline $4 \mathrm{X}-1,20$ & 28.70 & 60.31 & 20.76 & 11.37 & 4.45 & 1.98 & 1.13 & 0.00 & 0.00 & 0.00 & & 4.71 & 8.30 & 1.06 & -0.64 & \\
\hline $4 X-2,32-34$ & 29.84 & 51.63 & 20.85 & 16.88 & 8.44 & 1.49 & 0.71 & 0.00 & 0.00 & 0.00 & & 5.25 & 8.11 & 1.11 & -0.48 & IA \\
\hline $6 \times-1,5-7$ & 39.05 & 42.60 & 14.51 & 13.11 & 18.73 & 4.68 & 6.36 & 0.00 & 0.00 & 0.00 & & 9.61 & 7.56 & 1.52 & -0.68 & \\
\hline $6 \times-3,56-59$ & 42.58 & 44.83 & 19.45 & 13.96 & 4.65 & 1.69 & 2.44 & 3.80 & 7.65 & 1.54 & & 27.09 & 7.39 & 2.14 & -4.44 & \\
\hline $6 \mathrm{X}-3,130^{*}$ & 43.30 & 43.07 & 20.16 & 14.66 & 10.54 & 2.29 & 2.78 & 2.33 & 4.19 & 0.00 & & 15.82 & 7.57 & 1.76 & -2.47 & \\
\hline $6 \times-4,66-68$ & 44.18 & 59.45 & 19.21 & 9.60 & 1.83 & 1.37 & 8.54 & 0.00 & 0.00 & 0.00 & & 7.16 & 8.12 & 1.39 & -1.46 & \\
\hline $7 \mathrm{X}-3,17-20$ & 51.69 & 51.20 & 20.38 & 15.91 & 9.94 & 1.99 & 0.58 & 0.00 & 0.00 & 0.00 & & 5.48 & 8.07 & 1.15 & -0.51 & \\
\hline $7 X-4,125^{*}$ & 54.27 & 61.00 & 20.00 & 13.00 & 4.50 & 1.50 & 0.00 & 0.00 & 0.00 & 0.00 & & 4.18 & 8.35 & 0.97 & -0.43 & \\
\hline $7 \mathrm{X}-5,130^{*}$ & 55.82 & 51.20 & 21.37 & 16.90 & 7.95 & 1.99 & 0.59 & 0.00 & 0.00 & 0.00 & & 5.29 & 8.10 & 1.11 & -0.49 & \\
\hline $7 X-5,132-134$ & 55.86 & 54.55 & 22.81 & 14.88 & 5.95 & 0.99 & 0.82 & 0.00 & 0.00 & 0.00 & & 4.74 & 8.22 & 1.04 & -0.47 & \\
\hline $7 X-6,24^{*}$ & 56.26 & 53.08 & 19.66 & 14.25 & 9.34 & 1.97 & 1.71 & 0.00 & 0.00 & 0.00 & & 5.76 & 8.08 & 1.19 & -0.66 & \\
\hline $8 \times-2,110^{*}$ & 60.00 & 49.74 & 21.88 & 14.92 & 10.94 & 1.99 & 0.52 & 0.00 & 0.00 & 0.00 & & 5.57 & 8.05 & 1.15 & -0.50 & \\
\hline $8 \mathrm{X}-3,49-50$ & 61.52 & 62.01 & 17.72 & 11.81 & -4.92 & 1.97 & 1.57 & 0.00 & 0.00 & 0.00 & & 4.92 & 8.29 & 1.11 & -0.73 & \\
\hline $1 \overline{1 X}-2, \overline{62}-\overline{64}$ & $80 . \overline{12}$ & $59.2 \overline{2}$ & $\overline{18.26}$ & $1 \overline{3.32}$ & $5 . \overline{92}$ & $1 . \overline{97}$ & $1.3 \overline{0}$ & 0.00 & $\overline{0.00}$ & $0 . \overline{00}$ & & $5 . \overline{04}$ & 8.24 & 1.12 & $-\overline{0.67}$ & \\
\hline $12 \times-1,58-60$ & 88.08 & 54.06 & 20.27 & 14.00 & 6.28 & 1.93 & 3.46 & 0.00 & 0.00 & 0.00 & & 6.06 & 8.10 & 1.23 & -0.85 & \\
\hline $13 X-2,27-29$ & 97.56 & 66.86 & 17.96 & 10.98 & 2.00 & 2.00 & 0.21 & 0.00 & 0.00 & 0.00 & & 3.92 & 8.45 & 0.93 & -0.50 & \\
\hline $13 X-5,18-20$ & 100.27 & 59.83 & 16.67 & 13.73 & 5.39 & 2.45 & 1.92 & 0.00 & 0.00 & 0.00 & & 5.37 & 8.21 & 1.17 & -0.78 & \\
\hline $13 X-8,12-14$ & 103.57 & 55.37 & 19.77 & 13.35 & 7.91 & 2.47 & 1.13 & 0.00 & 0.00 & 0.00 & & 5.42 & 8.15 & 1.16 & -0.65 & IB \\
\hline $15 X-1,32-34$ & 116.32 & 54.67 & 16.90 & 14.41 & 10.93 & 2.49 & 0.60 & 0.00 & 0.00 & 0.00 & & 5.62 & 8.09 & 1.19 & -0.59 & \\
\hline $17 X-2,75-77$ & 136.36 & 62.69 & 14.93 & 11.94 & 7.96 & 1.99 & 0.50 & 0.00 & 0.00 & 0.00 & & 4.84 & 8.27 & 1.11 & -0.63 & \\
\hline $20 \mathrm{X}-1,97-100$ & 164.47 & 46.60 & 15.84 & 15.38 & 9.50 & 3.17 & 4.52 & 4.11 & 0.82 & 0.05 & & 12.43 & 7.64 & 1.68 & -1.79 & \\
\hline $20 \times-2,57-59$ & 165.59 & 57.80 & 18.93 & 13.95 & 5.98 & 2.99 & 0.35 & 0.00 & 0.00 & 0.00 & & 4.99 & 8.22 & 1.11 & -0.60 & \\
\hline 146-892D- & & & & & & & & & & & & & & & & \\
\hline $4 X-1,40-42$ & 27.90 & 50.35 & 20.33 & 14.52 & 8.23 & 3.39 & 3.17 & 0.00 & 0.00 & 0.00 & & 6.66 & 7.98 & 1.29 & -0.83 & \\
\hline $5 X-1,60-62$ & 37.60 & 64.71 & 16.67 & 11.76 & 3.92 & 0.98 & 1.96 & 0.00 & 0.00 & 0.00 & & 4.64 & 8.35 & 1.06 & -0.71 & \\
\hline $5 \times-4,9-14$ & 41.59 & 50.91 & 20.17 & 12.97 & 9.13 & 2.88 & 3.93 & 0.00 & 0.00 & 0.00 & & 6.86 & 7.97 & 1.32 & -0.89 & \\
\hline $5 \times-4,49-52$ & 41.99 & 50.03 & 20.01 & 11.83 & 7.73 & 1.36 & 9.03 & 0.00 & 0.00 & 0.00 & & 8.31 & 7.87 & 1.46 & -1.21 & \\
\hline $5 \mathrm{X}-\mathrm{CC}, 7-12$ & 43,03 & 49.52 & 20.26 & 11.25 & 7.20 & 1.80 & 9.97 & 0.00 & 0.00 & 0.00 & & 8.72 & 7.84 & 1.50 & -1.28 & \\
\hline $6 \mathrm{X}-1,48-51$ & 46.98 & 33.33 & 20.16 & 13.57 & 7.75 & 2.71 & 5.81 & 8.53 & 8.14 & 0.00 & & 29.03 & 6.93 & 2.18 & -2.78 & \\
\hline $6 \mathrm{X}-1,120-122$ & 47.70 & 44.20 & 19.75 & 15.99 & 10.82 & 3.29 & 5.95 & 0.00 & 0.00 & 0.00 & & 8.23 & 7.76 & 1.41 & -0.85 & \\
\hline $6 \mathrm{X}-3,26-29$ & 49.51 & 26.74 & 11.88 & 18.57 & 13.74 & 3.34 & 6.41 & 11.13 & 8.19 & 0.00 & & 32.75 & 6.53 & 2.16 & -1.57 & IA \\
\hline $6 \mathrm{X}-5,79-82$ & 53.04 & 54.28 & 17.76 & 15.30 & 8.88 & 2.47 & 1.31 & 0.00 & 0.00 & 0.00 & & 5.70 & 8.09 & 1.19 & -0.65 & \\
\hline $7 X-1,69-72$ & 54.69 & 48.12 & 21.33 & 17.86 & 9.92 & 1.98 & 0.78 & 0.00 & 0.00 & 0.00 & & 5.70 & 8.02 & 1.15 & -0.48 & \\
\hline $7 \mathrm{X}-3,70-73$ & 57.46 & 54.73 & 20.90 & 13.93 & 7.96 & 1.99 & 0.50 & 0.00 & 0.00 & 0.00 & & 5.07 & $\begin{array}{l}8.02 \\
8.17\end{array}$ & 1.10 & -0.54 & \\
\hline $7 \times-4,48-51$ & 58.74 & 49.80 & 18.92 & 14.94 & 11.95 & 3.98 & 0.40 & 0.00 & 0.00 & 0.00 & & 6.18 & 7.98 & 1.24 & -0.58 & \\
\hline $8 X-1,34-36$ & 62.04 & 54.51 & 18.83 & 14.87 & 7.93 & 2.97 & 0.88 & 0.00 & 0.00 & 0.00 & & 5.53 & 8.12 & 1.17 & -0.64 & \\
\hline $8 X-3,155-157$ & 66.05 & 57.76 & 21.91 & 13.44 & 4.48 & 1.99 & 0.41 & 0.00 & 0.00 & 0.00 & & 4.56 & 8.28 & 1.02 & -0.51 & \\
\hline$-9 \overline{\mathrm{X}-3}, \overline{45}-4 \overline{7}$ & $72 . \overline{06}$ & 52.30 & $\overline{22} .41$ & $1 \overline{5.94}$ & $7 . \overline{97}$ & $1 . \overline{00}$ & $0.3 \overline{8}$ & 0.00 & $\overline{0.00}$ & $0 . \overline{00}$ & & $4 . \overline{88}$ & $\overline{8.16}$ & $\overline{1.05}$ & $-\overline{0.42}$ & \\
\hline $9 \times-6,3-5$ & 74.88 & 50.51 & 21.79 & 15.85 & 8.91 & 1.98 & 0.96 & 0.00 & 0.00 & 0.00 & & 5.52 & 8.08 & 1.14 & -0.54 & \\
\hline $10 \mathrm{X}-2,40-42$ & 101.15 & 57.28 & 8.95 & 8.06 & 9.85 & 5.37 & 3.64 & 1.92 & 1.56 & 3.38 & & 22.69 & 7.62 & 2.03 & -30.79 & $\mathbb{I B}$ \\
\hline $10 \times-3,40-42$ & 102.65 & 63.33 & 10.40 & 9.92 & 6.62 & 4.25 & 5.48 & 0.00 & 0.00 & 0.00 & & 7.21 & 8.08 & 1.43 & -1.33 & IB \\
\hline $10 \times-3,120-122$ & 103.45 & 56.69 & 10.22 & 9.29 & 10.22 & 6.51 & 7.07 & 0.00 & 0.00 & 0.00 & & 8.98 & 7.83 & 1.58 & -1.28 & \\
\hline $10 X-7,44-46$ & 108.27 & 69.05 & 16.77 & 7.89 & 2.96 & 1.97 & 1.36 & 0.00 & 0.00 & 0.00 & & 4.32 & 8.45 & 1.02 & -0.74 & \\
\hline
\end{tabular}


APPENDIX A (continued).

\begin{tabular}{|c|c|c|c|c|c|c|c|c|c|c|c|c|c|c|c|}
\hline \multirow{2}{*}{$\begin{array}{l}\text { Core, section, } \\
\text { interval }(\mathrm{cm})\end{array}$} & \multirow{2}{*}{$\begin{array}{l}\text { Depth } \\
\text { (mbsf) }\end{array}$} & \multicolumn{9}{|c|}{ Grain size $(\phi)$} & \multicolumn{2}{|c|}{ Mean size } & \multirow[b]{2}{*}{ Sorting } & \multirow[b]{2}{*}{ Skewness } & \multirow{2}{*}{$\begin{array}{c}\text { Lithologic } \\
\text { unit }\end{array}$} \\
\hline & & $>8$ & 8 & 7 & 6 & 5 & 4 & 3 & 2 & 1 & $(\mu \mathrm{m})$ & (ф) & & & \\
\hline $11 X-2,114-116$ & 112.14 & 59.75 & 22.90 & 11.95 & 3.49 & 1.49 & 0.42 & 0.00 & 0.00 & 0.00 & 4.21 & 8.35 & 0.96 & -0.46 & \\
\hline $12 \mathrm{X}-2,48-50$ & 120.98 & 56.28 & 21.42 & 14.94 & 4.98 & 1.99 & 0.39 & 0.00 & 0.00 & 0.00 & 4.69 & 8.24 & 1.04 & -0.49 & \\
\hline $15 X-1,113-115$ & 148.63 & 54.98 & 20.99 & 16.49 & 5.50 & 2.00 & 0.04 & 0.00 & 0.00 & 0.00 & 4.70 & 8.21 & 1.04 & -0.44 & \\
\hline $15 \mathrm{X}-3,109-112$ & 151.59 & 53.77 & 20.91 & 15.93 & 7.47 & 1.49 & 0.43 & 0.00 & 0.00 & 0.00 & 4.95 & 8.17 & 1.07 & -0.47 & IB \\
\hline $16 \mathrm{X}-4,81-83$ & 161.84 & 63.63 & 18.89 & 12.43 & 3.48 & 0.99 & 0.57 & 0.00 & 0.00 & 0.00 & 4.08 & 8.39 & 0.95 & -0.47 & \\
\hline $16 \mathrm{X}-\mathrm{CC}, 10-12$ & 164.25 & 58.44 & 16.97 & 13.20 & 3.30 & 1.89 & 6.21 & 0.00 & 0.00 & 0.00 & 6.69 & 8.11 & 1.33 & -1.19 & \\
\hline
\end{tabular}

Notes: * $=$ samples used for calibration of the compensation factors of the Lab-Tec 100. Solid lines $=$ unit boundaries; dashed lines $=$ subunit boundaries. $\mathrm{Tr}=$ transitional unit. 
APPENDIX B

Calibration of Grain-size Analyses Made by Lab-Tec 100

\begin{tabular}{|c|c|c|c|c|c|c|c|c|c|}
\hline \multirow{2}{*}{$\begin{array}{l}\text { Core, section, } \\
\text { interval }(\mathrm{cm})\end{array}$} & $\mathrm{De}$ & & & & mpensat & factor $(\phi$ & & & \\
\hline & (mbsf) & $>8$ & 8 & 7 & 6 & 5 & 4 & 3 & 2 \\
\hline 146-888B- & & & & & & & & & \\
\hline $2 \mathrm{H}-6,70$ & 13.70 & 0.724 & 0.300 & 0.327 & 0.710 & 2.000 & 4.880 & 0.000 & 0.000 \\
\hline $5 \mathrm{H}-2,15$ & 35.65 & 21.500 & 7.000 & 5.000 & 7.000 & 140.000 & 0.000 & 0.000 & 0.000 \\
\hline $5 \mathrm{H}-4,9$ & 38.72 & 0.724 & 0.300 & 0.327 & 0.710 & 2.000 & 4.880 & 0.000 & 0.000 \\
\hline $5 \mathrm{H}-5,138$ & 41.38 & 0.724 & 0.300 & 0.327 & 0.710 & 2.000 & 4.880 & 0.000 & 0.000 \\
\hline $8 \mathrm{H}-\mathrm{I}, 100$ & 63.50 & 0.729 & 0.278 & 0.290 & 0.718 & 1.768 & 4.880 & 0.000 & 0.000 \\
\hline $9 \mathrm{H}-4,80$ & 77.30 & 0.729 & 0.278 & 0.290 & 0.718 & 1.768 & 4.880 & 0.000 & 0.000 \\
\hline $10 \mathrm{H}-1,73$ & 82.23 & 0.729 & 0.278 & 0.290 & 0.718 & 1.768 & 4.880 & 0.000 & 0.000 \\
\hline $10 \mathrm{H}-7,32$ & 90.82 & 0.729 & 0.278 & 0.290 & 0.718 & 1.768 & 4.880 & 0.000 & 0.000 \\
\hline $11 \mathrm{H}-2,32$ & 92.78 & 0.729 & 0.278 & 0.290 & 0.718 & 1.768 & 4.880 & 0.000 & 0.000 \\
\hline $11 \mathrm{H}-5,102$ & 97.92 & 0.729 & 0.278 & 0.290 & 0.718 & 1.768 & 4.880 & 0.000 & 0.000 \\
\hline $14 \mathrm{H}-1,131$ & 119.41 & 0.729 & 0.278 & 0.290 & 0.718 & 1.768 & 4.880 & 0.000 & 0.000 \\
\hline $14 \mathrm{H}-5,74$ & 124.84 & 0.729 & 0.278 & 0.290 & 0.718 & 1.768 & 4.880 & 0.000 & 0.000 \\
\hline $15 \mathrm{H}-1,123$ & 128.83 & 0.729 & 0.278 & 0.290 & 0.718 & 1.768 & 4.880 & 0.000 & 0.000 \\
\hline $16 \mathrm{H}-3,25$ & 140.83 & 0.729 & 0.278 & 0.290 & 0.718 & 1.768 & 4.880 & 0.000 & 0.000 \\
\hline $16 \mathrm{H}-4,9$ & 141.69 & 0.729 & 0.278 & 0.290 & 0.718 & 1.768 & 4.880 & 0.000 & 0.000 \\
\hline $17 \mathrm{H}-4,15$ & 151.25 & 0.729 & 0.278 & 0.290 & 0.718 & 1.768 & 4.880 & 0.000 & 0.000 \\
\hline $17 \mathrm{H}-4,30$ & 151.40 & 0.733 & 0.256 & 0.252 & 0.725 & 1.535 & 4.880 & 0.000 & 0.000 \\
\hline $18 X-2,32$ & 157.92 & 1.734 & 0.845 & 0.661 & 1.092 & 2.678 & 13.293 & 0.000 & 0.000 \\
\hline $18 X-4,90$ & 161.50 & 4.470 & 2.280 & 1.730 & 2.550 & 6.500 & 35.000 & 0.000 & 0.000 \\
\hline $19 X-2,70$ & 167.80 & 2.690 & 1.320 & 1.490 & 2.820 & 3.500 & 45.000 & 0.000 & 0.000 \\
\hline $19 X-4,98$ & 171.08 & 2.690 & 1.320 & 1.490 & 2.820 & 3.500 & 45.000 & 0.000 & 0.000 \\
\hline $20 \mathrm{X}-1,30$ & 178.40 & 2.605 & 1.105 & 1.275 & 2.435 & 4.000 & 45.000 & 0.000 & 0.000 \\
\hline $21 X-1,30$ & 184.90 & 2.520 & 0.890 & 1.060 & 2.050 & 4.500 & 45.000 & 0.000 & 0.000 \\
\hline $25 X-1.15$ & 217.55 & 2.520 & 0.890 & 1.060 & 2.050 & 4.500 & 45.000 & 0.000 & 0.000 \\
\hline $26 \mathrm{H}-1,141$ & 228.31 & 2.520 & 0.890 & 1.060 & 2.050 & 4.500 & 45.000 & 0.000 & 0.000 \\
\hline $26 \mathrm{H}-2,20$ & 228.60 & 1.849 & 0.718 & 0.949 & 2.920 & 5.100 & 29.500 & 0.000 & 0.000 \\
\hline $28 \mathrm{H}-1,64$ & 243.94 & 1.849 & 0.718 & 0.949 & 2.920 & 5.100 & 29.500 & 0.000 & 0.000 \\
\hline $30 \mathrm{H}-1,96$ & 261.76 & 1.849 & 0.718 & 0.949 & 2.920 & 5.100 & 29.500 & 0.000 & 0.000 \\
\hline $31 \mathrm{H}-4,5$ & 272.35 & 1.849 & 0.718 & 0.949 & 2.920 & 5.100 & 29.500 & 0.000 & 0.000 \\
\hline $33 \mathrm{H}-1,42$ & 283.22 & 1.177 & 0.545 & 0.838 & 3.790 & 5.700 & 14.000 & 0.000 & 0.000 \\
\hline $36 \mathrm{H}-1,25$ & 310.25 & 0.821 & 0.465 & 0.654 & 2.362 & 3.675 & 8.500 & 0.000 & 0.000 \\
\hline $36 \mathrm{H}-6,55$ & 316.28 & 0.821 & 0.465 & 0.654 & 2.362 & 3.675 & 8.500 & 0.000 & 0.000 \\
\hline $37 \mathrm{H}-7,7$ & 319.88 & 0.821 & 0.465 & 0.654 & 2.362 & 3.675 & 8.500 & 0.000 & 0.000 \\
\hline $40 \mathrm{H}-1,27$ & 348.27 & 0.464 & 0.385 & 0.469 & 0.933 & 1.650 & 3.000 & 0.000 & 0.000 \\
\hline $42 X-1,30$ & 366.80 & 0.617 & 0.434 & 0.515 & 0.817 & 1.725 & 1.500 & 0.000 & 0.000 \\
\hline $44 X-4,66$ & 390.66 & 0.770 & 0.482 & 0.560 & 0.700 & 1.800 & 0.000 & 0.000 & 0.000 \\
\hline $45 X-1,30$ & 395.30 & 0.770 & 0.482 & 0.560 & 0.700 & 1.800 & 0.000 & 0.000 & 0.000 \\
\hline $45 X-2,85$ & 397.35 & 0.770 & 0.482 & 0.560 & 0.700 & 1.800 & 0.000 & 0.000 & 0.000 \\
\hline $50 \mathrm{X}-\mathrm{CC}, 3$ & 442.53 & 0.770 & 0.482 & 0.560 & 0.700 & 1.800 & 0.000 & 0.000 & 0.000 \\
\hline $53 \mathrm{X}-\mathrm{CC}, 30$ & 460.80 & 0.614 & 0.362 & 0.564 & 1.459 & 3.500 & 4.880 & 0.000 & 0.000 \\
\hline $54 X-1,10$ & 469.50 & 0.614 & 0.362 & 0.564 & 1.459 & 3.500 & 4.880 & 0.000 & 0.000 \\
\hline $56 \mathrm{X}-1,36$ & 487.66 & 0.614 & 0.362 & 0.564 & 1.459 & 3.500 & 4.880 & 0.000 & 0.000 \\
\hline $57 \overline{\mathrm{X}-1}, \overline{36}$ & $46 \overline{9.65}$ & $\overline{0.461}$ & $\overline{0} .1 \overline{84}$ & $0 . \overline{347}$ & $\overline{0.830}$ & $\overline{4} .1 \overline{00}$ & $60 . \overline{000}$ & $0 . \overline{000}$ & $\overline{0.0} 00$ \\
\hline $57 X-2,103$ & 498.73 & 0.461 & 0.184 & 0.347 & 0.830 & 4.100 & 60.000 & 0.000 & 0.000 \\
\hline $58 \mathrm{X}-1,40$ & 505.50 & 0.461 & 0.184 & 0.347 & 0.830 & 4.100 & 60.000 & 0.000 & 0.000 \\
\hline $58 X-3,20$ & 509.43 & 0.461 & 0.184 & 0.347 & 0.830 & 4.100 & 60.000 & 0.000 & 0.000 \\
\hline $59 X-1,20$ & 514.20 & 0.461 & 0.184 & 0.347 & 0.830 & 4.100 & 60.000 & 0.000 & 0.000 \\
\hline $60 \mathrm{X}-\mathrm{CC}, 22$ & 515.62 & 0.461 & 0.184 & 0.347 & 0.830 & 4.100 & 60.000 & 0.000 & 0.000 \\
\hline $61 X-3,60$ & 526.40 & 0.461 & 0.184 & 0.347 & 0.830 & 4.100 & 60.000 & 0.000 & 0.000 \\
\hline $62 X-2,95$ & 533.92 & 0.461 & 0.184 & 0.347 & 0.830 & 4.100 & 60.000 & 0.000 & 0.000 \\
\hline $63 \times-1,77$ & 541.17 & 0.461 & 0.184 & 0.347 & 0.830 & 4.100 & 60.000 & 0.000 & 0.000 \\
\hline $63 X-4,47$ & 545.37 & 0.461 & 0.184 & 0.347 & 0.830 & 4.100 & 60.000 & 0.000 & 0.000 \\
\hline $64 X-1,72$ & 549.92 & 0.461 & 0.184 & 0.347 & 0.830 & 4.100 & 60.000 & 0.000 & 0.000 \\
\hline $64 X-4,62$ & 554.32 & 0.461 & 0.184 & 0.347 & 0.830 & 4.100 & 60.000 & 0.000 & 0.000 \\
\hline $65 X-6,31$ & 565.91 & 0.461 & 0.184 & 0.347 & 0.830 & 4.100 & 60.000 & 0.000 & 0.000 \\
\hline $146-889 \mathrm{~A}-$ & & & & & & & & & \\
\hline $1 \mathrm{H}-1,30$ & 20.30 & 0.487 & 0.152 & 0.130 & 0.330 & 2.500 & 12.000 & 0.000 & 0.000 \\
\hline $1 \mathrm{H}-4,90$ & 25.40 & 0.487 & 0.152 & 0.130 & 0.330 & 2.500 & 12.000 & 0.000 & 0.000 \\
\hline IH- 5,88 & 26.88 & 0.487 & 0.152 & 0.130 & 0.330 & 2.500 & 12.000 & 0.000 & 0.000 \\
\hline $2 \mathrm{H}-1,46$ & 29.96 & 0.487 & 0.152 & 0.130 & 0.330 & 2.500 & 12.000 & 0.000 & 0.000 \\
\hline $2 \mathrm{H}-5,100$ & 36.50 & 0.487 & 0.152 & 0.130 & 0.330 & 2.500 & 12.000 & 0.000 & 0.000 \\
\hline $2 \mathrm{H}-7,90$ & 39.40 & 0.487 & 0.152 & 0.130 & 0.330 & 2.500 & 12.000 & 0.000 & 0.000 \\
\hline $3 \mathrm{H}-2,40$ & 39.92 & 0.487 & 0.152 & 0.130 & 0.330 & 2.500 & 12.000 & 0.000 & 0.000 \\
\hline $3 \mathrm{H}-5,37$ & 44.41 & 0.487 & 0.152 & 0.130 & 0.330 & 2.500 & 12.000 & 0.000 & 0.000 \\
\hline $3 \mathrm{H}-\mathrm{CC}, 30$ & 49.68 & 0.487 & 0.152 & 0.130 & 0.330 & 2.500 & 12.000 & 0.000 & 0.000 \\
\hline $4 \mathrm{H}-1,50$ & 49.00 & 0.487 & 0.152 & 0.130 & 0.330 & 2.500 & 12.000 & 0.000 & 0.000 \\
\hline $4 \mathrm{H}-4,10$ & 52.03 & 0.487 & 0.152 & 0.130 & 0.330 & 2.500 & 12.000 & 0.000 & 0.000 \\
\hline $4 \mathrm{H}-7,80$ & 56.86 & 0.487 & 0.152 & 0.130 & 0.330 & 2.500 & 12.000 & 0.000 & 0.000 \\
\hline $5 \mathrm{H}-1,92$ & 58.92 & 0.487 & 0.152 & 0.130 & 0.330 & 2.500 & 12.000 & 0.000 & 0.000 \\
\hline $5 \mathrm{H}-1,107$ & 62.02 & 0.487 & 0.152 & 0.130 & 0.330 & 2.500 & 12.000 & 0.000 & 0.000 \\
\hline $5 \mathrm{H}-4,115$ & 63.57 & 0.487 & 0.152 & 0.130 & 0.330 & 2.500 & 12.000 & 0.000 & 0.000 \\
\hline $6 \mathrm{H}-3,53$ & 70.15 & 0.487 & 0.152 & 0.130 & 0.330 & 2.500 & 12.000 & 0.000 & 0.000 \\
\hline $6 \mathrm{H}-6,53$ & 74.65 & 0.487 & 0.152 & 0.130 & 0.330 & 2.500 & 12.000 & 0.000 & 0.000 \\
\hline $6 \mathrm{H}-7,58$ & 77.70 & 0.487 & 0.152 & 0.130 & 0.330 & 2.500 & 12.000 & 0.000 & 0.000 \\
\hline $7 \mathrm{H}-1,60$ & 77.60 & 0.487 & 0.152 & 0.130 & 0.330 & 2.500 & 12.000 & 0.000 & 0.000 \\
\hline $7 \mathrm{H}-4,40$ & 81.05 & 0.487 & 0.152 & 0.130 & 0.330 & 2.500 & 12.000 & 0.000 & 0.000 \\
\hline $7 \mathrm{H}-4,50$ & 81.15 & 0.487 & 0.152 & 0.130 & 0.330 & 2.500 & 12.000 & 0.000 & 0.000 \\
\hline $7 \mathrm{H}-6,37$ & 84.00 & 0.487 & 0.152 & 0.130 & 0.330 & 2.500 & 12.000 & 0.000 & 0.000 \\
\hline $8 \mathrm{H}-1,20$ & 86.70 & 0.487 & 0.152 & 0.130 & 0.330 & 2.500 & 12.000 & 0.000 & 0.000 \\
\hline $8 \mathrm{H}-3,60$ & 90.10 & 0.487 & 0.152 & 0.130 & 0.330 & 2.500 & 12.000 & 0.000 & 0.000 \\
\hline $9 \overline{\mathrm{H}}-\mathrm{I}, \overline{84}$ & $\overline{95.34}$ & $0.4 \overline{87}$ & $0 . \overline{152}$ & $\overline{0.130}$ & $\overline{0} .3 \overline{30}$ & 2.500 & 12.000 & $\overline{0.000}$ & $0 . \overline{000}$ \\
\hline $9 \mathrm{H}-8,56$ & 103.02 & 0.487 & 0.152 & 0.130 & 0.330 & 2.500 & 12.000 & 0.000 & 0.000 \\
\hline $10 \mathrm{H}-1,110$ & 105.10 & 0.487 & 0.152 & 0.130 & 0.330 & 2.500 & 12.000 & 0.000 & 0.000 \\
\hline $10 \mathrm{H}-4,50$ & 109.00 & 0.487 & 0.152 & 0.130 & 0.330 & 2.500 & 12.000 & 0.000 & 0.000 \\
\hline
\end{tabular}


APPENDIX B (continued)

\begin{tabular}{|c|c|c|c|c|c|c|c|c|c|}
\hline & Depth & & & & mpensa & factor $(C$ & & & \\
\hline & (mbsf) & $>8$ & 8 & 7 & 6 & 5 & 4 & 3 & 2 \\
\hline $10 \mathrm{H}-6,135$ & 112.95 & 0.487 & 0.152 & 0.130 & 0.330 & 2.500 & 12.000 & 0.000 & 0.000 \\
\hline $11 \mathrm{H}-1,45$ & 113.95 & 0.487 & 0.152 & 0.130 & 0.330 & 2.500 & 12.000 & 0.000 & 0.000 \\
\hline $11 \mathrm{H}-3,132$ & 117.82 & 0.487 & 0.152 & 0.130 & 0.330 & 2.500 & 12.000 & 0.000 & 0.000 \\
\hline $11 \mathrm{H}-4,55$ & 118.55 & 0.487 & 0.152 & 0.130 & 0.330 & 2.500 & 12.000 & 0.000 & 0.000 \\
\hline $12 \mathrm{H}-3,122$ & 123.13 & 0.487 & 0.152 & 0.130 & 0.330 & 2.500 & 12.000 & 0.000 & 0.000 \\
\hline $12 \mathrm{H}-6,25$ & 126.66 & 0.487 & 0.152 & 0.130 & 0.330 & 2.500 & 12.000 & 0.000 & 0.000 \\
\hline $13 \mathrm{H}-\mathrm{CC}, 10$ & 127.42 & 0.487 & 0.152 & 0.130 & 0.330 & 2.500 & 12.000 & 0.000 & 0.000 \\
\hline $14 \mathrm{H}-1,38$ & 128.38 & 0.358 & 0.240 & 0.250 & 0.240 & 0,450 & 2.800 & 0.000 & 0.000 \\
\hline $17 X-1,3$ & 130.13 & 0.358 & 0.240 & 0.250 & 0.240 & 0.450 & 2.800 & 0.000 & 0.000 \\
\hline $17 X-1,30$ & 130.40 & 0.358 & 0.240 & 0.250 & 0.240 & 0.450 & 2.800 & 0.000 & 0.000 \\
\hline $17 X-2,50$ & 131.26 & 0.358 & 0.240 & 0.250 & 0.240 & 0.450 & 2.800 & 0.000 & 0.000 \\
\hline $18 X-1,25$ & 139.85 & 0.358 & 0.240 & 0.250 & 0.240 & 0.450 & 2.800 & 0.000 & 0.000 \\
\hline $18 \mathrm{X}-2,70$ & 141.73 & 0.358 & 0.240 & 0.250 & 0.240 & 0.450 & 2.800 & 0.000 & 0.000 \\
\hline $18 \times-5,110$ & 145.61 & 0.358 & 0.240 & 0.250 & 0.240 & 0.450 & 2.800 & 0.000 & 0.000 \\
\hline $18 \mathrm{X}-\mathrm{CC}, 20$ & 147.23 & 0.358 & 0.240 & 0.250 & 0.240 & 0.450 & 2.800 & 0.000 & 0.000 \\
\hline $19 \times 1,60$ & 149.70 & 0.358 & 0.240 & 0.250 & 0.240 & 0.450 & 2.800 & 0.000 & 0.000 \\
\hline $19 X-3,30$ & 152.20 & 0.358 & 0.240 & 0.250 & 0.240 & 0.450 & 2.800 & 0.000 & 0.000 \\
\hline $19 X-4,145$ & 154.86 & 0.358 & 0.240 & 0.250 & 0.240 & 0.450 & 2.800 & 0.000 & 0.000 \\
\hline $20 \mathrm{X}-2,110$ & 159.50 & 0.358 & 0.240 & 0.250 & 0.240 & 0.450 & 2.800 & 0.000 & 0.000 \\
\hline $20 \mathrm{X}-3,20$ & 161.20 & 0.358 & 0.240 & 0.250 & 0.240 & 0.450 & 2.800 & 0.000 & 0.000 \\
\hline $20 \times-3,40$ & 161.80 & 0.358 & 0.240 & 0.250 & 0.240 & 0.450 & 2.800 & 0.000 & 0.000 \\
\hline $20 X-5,20$ & 162.00 & 0.358 & 0.240 & 0.250 & 0.240 & 0.450 & 2.800 & 0.000 & 0.000 \\
\hline $22 \mathrm{X}-1,20$ & 177.70 & 0.358 & 0.240 & 0.250 & 0.240 & 0.450 & 2.800 & 0.000 & 0.000 \\
\hline $22 \mathrm{X}-2,20$ & 179.20 & 0.358 & 0.240 & 0.250 & 0.240 & 0.450 & 2.800 & 0.000 & 0.000 \\
\hline $22 \times-4,70$ & 181.80 & 0.358 & 0.240 & 0.250 & 0.240 & 0.450 & 2.800 & 0.000 & 0.000 \\
\hline $22 X-5,75$ & 183.85 & 0.358 & 0.240 & 0.250 & 0.240 & 0.450 & 2.800 & 0.000 & 0.000 \\
\hline $24 X-4,30$ & 191.92 & 0.358 & 0.240 & 0.250 & 0.240 & 0.450 & 2.800 & 0.000 & 0.000 \\
\hline $24 X-5,80$ & 193.92 & 0.358 & 0.240 & 0.250 & 0.240 & 0.450 & 2.800 & 0.000 & 0.000 \\
\hline $146-890 B$ & & & & & & & & & \\
\hline $1 \mathrm{H}-1,5$ & 0.05 & 0.237 & 0.104 & 0.149 & 0.355 & 1.400 & 28.000 & 0.000 & 0.000 \\
\hline $1 \mathrm{H}-1,140$ & 1.40 & 0.237 & 0.104 & 0.149 & 0.355 & 1.400 & 28.000 & 0.000 & 0.000 \\
\hline $1 \mathrm{H}-2,80$ & 2.30 & 0.237 & 0.104 & 0.149 & 0.355 & 1.400 & 28.000 & 0.000 & 0.000 \\
\hline IH $-4,40$ & 6.42 & 0.237 & 0.104 & 0.149 & 0.355 & 1.400 & 28.000 & 0.000 & 0.000 \\
\hline $2 \mathrm{H}-1,125$ & 8.55 & 0.239 & 0.105 & 0.125 & 0.332 & 1.625 & 17.655 & 0.000 & 0.000 \\
\hline $2 \mathrm{H}-4,85$ & 12.65 & 0.239 & 0.105 & 0.125 & 0.332 & 1.625 & 17.655 & 0.000 & 0.000 \\
\hline $2 \mathrm{H}-6,85$ & 15.83 & 0.239 & 0.105 & 0.125 & 0.332 & 1.625 & 17.655 & 0.000 & 0.000 \\
\hline $3 \mathrm{H}-1,105$ & 17.85 & 0.239 & 0.105 & 0.125 & 0.332 & 1.625 & 17.655 & 0.000 & 0.000 \\
\hline $3 \mathrm{H}-3,10$ & 19.84 & 0.240 & 0.106 & 0.100 & 0.309 & 1.850 & 7.310 & 0.000 & 0.000 \\
\hline $3 \mathrm{H}-5,75$ & 23.49 & 0.240 & 0.089 & 0.095 & 0.341 & 2.075 & 29.155 & 0.000 & 0.000 \\
\hline $5 \mathrm{H}-1,12$ & 38.42 & 0.239 & 0.071 & 0.090 & 0.372 & 2.300 & 51.000 & 0.000 & 0.000 \\
\hline $5 \mathrm{H}-3,100$ & 41.92 & 0.235 & 0.071 & 0.064 & 0.244 & 1.750 & 36.000 & 0.000 & 0.000 \\
\hline $5 \mathrm{H}-5,66$ & 44.32 & 0.235 & 0.071 & 0.064 & 0.244 & $1: 750$ & 36.000 & 0.000 & 0.000 \\
\hline 5H-CC, 18 & 47.93 & 0.231 & 0.070 & 0.038 & 0.115 & 1.200 & 21.000 & 0.000 & 0.000 \\
\hline 146-891B & & & & & & & & & \\
\hline $4 \mathrm{X}-\mathrm{CC}, 1$ & 29.62 & 0.323 & 0.179 & 0.183 & 0.159 & 0.230 & 0.000 & 0.000 & 0.000 \\
\hline $8 X-1,7$ & 65.27 & 0.323 & 0.179 & 0.183 & 0.159 & 0.230 & 0.000 & 0.000 & 0.000 \\
\hline $14 X-1,37$ & 109.89 & 0.323 & 0.179 & 0.183 & 0.159 & 0.230 & 0.000 & 0.000 & 0.000 \\
\hline $15 X-1,12$ & 118.52 & 0.323 & 0.179 & 0.183 & 0.159 & 0.230 & 0.000 & 0.000 & 0.000 \\
\hline $16 \mathrm{X}-1,25$ & 127.55 & 0.329 & 0.170 & 0.243 & 0.249 & 0.230 & 0.000 & 0.000 & 0.000 \\
\hline $18 \mathrm{X}-\mathrm{CC}, 10$ & 148.20 & 0.323 & 0.179 & 0.183 & 0.159 & 0.230 & 0.000 & 0.000 & 0.000 \\
\hline $19 X-1,40$ & 154.30 & 0.323 & 0.179 & 0.183 & 0.159 & 0.230 & 0.000 & 0.000 & 0.000 \\
\hline $20 X-1,72$ & 163.42 & 0.316 & 0.188 & 0.123 & 0.069 & 0.230 & 0.000 & 0.000 & 0.000 \\
\hline $21 \mathrm{~N}-1,30$ & 171.90 & 0.323 & 0.179 & 0.183 & 0.159 & 0.230 & 0.000 & 0.000 & 0.000 \\
\hline $23 X-1,27$ & 180.77 & 0.323 & 0.179 & 0.183 & 0.159 & 0.230 & 0.000 & 0.000 & 0.000 \\
\hline $23 \mathrm{X}-2,24$ & 182.77 & 0.323 & 0.179 & 0.183 & 0.159 & 0.230 & 0.000 & 0.000 & -0.000 \\
\hline $25 \mathrm{X}-1,30$ & 198.50 & $0.0 \overline{89}$ & $0 . \overline{059}$ & $\overline{0.072}$ & $0.1 \overline{83}$ & $\overline{0.618}$ & $\overline{7.060}$ & 0.000 & $0 . \overline{000}$ \\
\hline $26 \times-1,37$ & 207.47 & 0.066 & 0.039 & 0.088 & 0.355 & 0.568 & 2.400 & 0.000 & 0.000 \\
\hline $27 X-1,8$ & 215.98 & 0.089 & 0.059 & 0.072 & 0.183 & 0.618 & 7.060 & 0.000 & 0.000 \\
\hline $28 \mathrm{X}-\mathrm{CC}, 25$ & 225.60 & 0.089 & 0.059 & 0.072 & 0.183 & 0.618 & 7.060 & 0.000 & 0.000 \\
\hline $29 X-1,8$ & 233.68 & 0.089 & 0.059 & 0.072 & 0.183 & 0.618 & 7.060 & 0.000 & 0.000 \\
\hline $30 \times-1,25$ & 237.85 & 0.089 & 0.059 & 0.072 & 0.183 & 0.618 & 7.060 & 0.000 & 0.000 \\
\hline $31 X-1,120$ & 243.60 & 0.120 & 0.078 & 0.076 & 0.131 & 0.300 & 1.500 & 0.000 & 0.000 \\
\hline $32 \mathrm{X}-\mathrm{CC}, 20$ & 252.19 & 0.089 & 0.059 & 0.072 & 0.183 & 0.618 & 7.060 & 0.000 & 0.000 \\
\hline $33 X-1,25$ & 260.45 & 0.115 & 0.061 & 0.068 & 0.115 & 0.900 & 22.000 & 0.000 & 0.000 \\
\hline $34 X-1,25$ & 263.35 & 0.089 & 0.059 & 0.072 & 0.183 & 0.618 & 7.060 & 0.000 & 0.000 \\
\hline $35 X-1,43$ & 269.43 & 0.089 & 0.059 & 0.072 & 0.183 & 0.618 & 7.060 & 0.000 & 0.000 \\
\hline $35 \mathrm{X}-\mathrm{CC}, 15$ & 270.79 & 0.089 & 0.059 & 0.072 & 0.183 & 0.618 & 7.060 & 0.000 & 0.000 \\
\hline $37 \mathrm{X}-1,10$ & 278.90 & 0.089 & 0.059 & 0.072 & 0.183 & 0.618 & 7.060 & 0.000 & 0.000 \\
\hline $37 X-1,25$ & 279.05 & 0.089 & 0.059 & 0.072 & 0.183 & 0.618 & 7.060 & 0.000 & 0.000 \\
\hline $38 \mathrm{X}-1,140$ & 287.80 & 0.089 & 0.059 & 0.072 & 0.183 & 0.618 & 7.060 & 0.000 & 0.000 \\
\hline $39 X-1,73$ & 295.83 & 0.089 & 0.059 & 0.072 & 0.183 & 0.618 & 7.060 & 0.000 & 0.000 \\
\hline $40 \times-1,75$ & 304.75 & 0.089 & 0.059 & 0.072 & 0.183 & 0.618 & 7.060 & 0.000 & 0.000 \\
\hline $40 X-2,25$ & 305.75 & 0.059 & 0.045 & 0.066 & 0.224 & 0.960 & 5.800 & 0.000 & 0.000 \\
\hline $41 X-1,55$ & 313.35 & 0.089 & 0.059 & 0.072 & 0.183 & 0.618 & 7.060 & 0.000 & 0.000 \\
\hline $42 \mathrm{X}-1,120$ & 322.80 & 0.089 & 0.059 & 0.072 & 0.183 & 0.618 & 7.060 & 0.000 & 0.000 \\
\hline $43 X-2,75$ & 331.42 & 0.089 & 0.059 & 0.072 & 0.183 & 0.618 & 7.060 & 0.000 & 0.000 \\
\hline $44 X-1,3$ & 339.33 & 0.089 & 0.059 & 0.072 & 0.183 & 0.618 & 7.060 & 0.000 & 0.000 \\
\hline $45 X-1,16$ & 348.36 & 0.089 & 0.059 & 0.072 & 0.183 & 0.618 & 7.060 & 0.000 & 0.000 \\
\hline $52 X-1,80$ & 411.30 & 0.089 & 0.059 & 0.072 & 0.183 & 0.618 & 7.060 & 0.000 & 0.000 \\
\hline $55 \mathrm{X}-2,48$ & 438.15 & 0.089 & 0.059 & 0.072 & 0.183 & 0.618 & 7.060 & 0.000 & 0.000 \\
\hline $56 \mathrm{X}-\mathrm{CC}, 20$ & 447.77 & 0.089 & 0.059 & 0.072 & 0.183 & 0.618 & 7.060 & 0.000 & 0.000 \\
\hline $58 \mathrm{X}-1,51$ & 464.01 & 0.089 & 0.059 & 0.072 & 0.183 & 0.618 & 7.060 & 0.000 & 0.000 \\
\hline $146-892 \mathrm{~A}-$ & & & & & & & & & \\
\hline $1 \mathrm{X}-1,30$ & 0.30 & 0.129 & 0.071 & 0.092 & 0.227 & 1.800 & 31.000 & 0.000 & 0.000 \\
\hline IX-1, 103 & 1.03 & 0.129 & 0.071 & 0.092 & 0.227 & 1.800 & 31.000 & 0.000 & 0.000 \\
\hline $1 \mathrm{X}-2,52$ & 2.03 & 0.129 & 0.071 & 0.092 & 0.227 & 1.800 & 31.000 & 0.000 & 0.000 \\
\hline
\end{tabular}


APPENDIX B (continued).

\begin{tabular}{|c|c|c|c|c|c|c|c|c|c|}
\hline \multirow{2}{*}{$\begin{array}{l}\text { Core, section, } \\
\text { interval (cm) }\end{array}$} & \multirow{2}{*}{$\begin{array}{l}\text { Depth } \\
\text { (mbsf) }\end{array}$} & & & & npensat & factor $(\phi$ & & & \\
\hline & & $>8$ & 8 & 7 & 6 & 5 & 4 & 3 & 2 \\
\hline $1 X-2,85$ & 2.36 & 0.129 & 0.071 & 0.092 & 0.227 & 1.800 & 31.000 & 0.000 & 0.000 \\
\hline $1 \mathrm{X}-3,33$ & 3.30 & 0.129 & 0.071 & 0.092 & 0.227 & 1.800 & 31.000 & 0.000 & 0.000 \\
\hline $1 \times-4,5$ & 3.59 & 0.129 & 0.071 & 0.092 & 0.227 & 1.800 & 31.000 & 0.000 & 0.000 \\
\hline $1 X-5,30$ & 4.00 & 0.230 & 0.112 & 0.136 & 0.295 & 1.800 & 60.500 & 0.000 & 0.000 \\
\hline $1 \mathrm{X}-\mathrm{CC}, 5$ & 4.24 & 0.230 & 0.112 & 0.136 & 0.295 & 1.800 & 60.500 & 0.000 & 0.000 \\
\hline $2 X-1,14$ & 9.64 & 0.230 & 0.112 & 0.136 & 0.295 & 1.800 & 60.500 & 0.000 & 0.000 \\
\hline $2 \mathrm{X}-1,50$ & 10.00 & 0.331 & 0.153 & 0.180 & 0.362 & 1.800 & 90.000 & 0.000 & 0.000 \\
\hline $2 X-1,70$ & 10.20 & 0.277 & 0.128 & 0.149 & 0.278 & 1.525 & 62.000 & 0.000 & 0.000 \\
\hline $2 X-2,130$ & 12.30 & 0.277 & 0.128 & 0.149 & 0.278 & 1.525 & 62.000 & 0.000 & 0.000 \\
\hline $2 X-3,55$ & 13.05 & 0.277 & 0.128 & 0.149 & 0.278 & 1.525 & 62.000 & 0.000 & 0.000 \\
\hline $3 \mathrm{X}-1,10$ & 19.10 & 0.277 & 0.128 & 0.149 & 0.278 & 1.525 & 62.000 & 0.000 & 0.000 \\
\hline $3 \mathrm{X}-1,120$ & 20.20 & 0.277 & 0.128 & 0.149 & 0.278 & 1.525 & 62.000 & 0.000 & 0.000 \\
\hline $3 \times-2,17$ & 20.67 & 0.277 & 0.128 & 0.149 & 0.278 & 1.525 & 62.000 & 0.000 & 0.000 \\
\hline $3 X-2,105$ & 21.55 & 0.277 & 0.128 & 0.149 & 0.278 & 1.525 & 62.000 & 0.000 & 0.000 \\
\hline $3 \mathrm{X}-3,32$ & 22.12 & 0.277 & 0.128 & 0.149 & 0.278 & 1.525 & 62.000 & 0.000 & 0.000 \\
\hline $3 \mathrm{X}-3,77$ & 22.57 & 0.277 & 0.128 & 0.149 & 0.278 & 1.525 & 62.000 & 0.000 & 0.000 \\
\hline $4 X-1,5$ & 28.55 & 0.222 & 0.102 & 0.118 & 0.193 & 1.250 & 34.000 & 0.000 & 0.000 \\
\hline $4 \mathrm{X}-1,40$ & 28.90 & 0.234 & 0.119 & 0.135 & 0.207 & 1.200 & 17.000 & 0.000 & 0.000 \\
\hline $4 \mathrm{X}-2,25$ & 29.70 & 0.234 & 0.119 & 0.135 & 0.207 & 1.200 & 17.000 & 0.000 & 0.000 \\
\hline $4 X-2,60$ & 31.12 & 0.234 & 0.119 & 0.135 & 0.207 & 1.200 & 17.000 & 0.000 & 0.000 \\
\hline $6 \mathrm{X}-1.25$ & 39.25 & 0.234 & 0.119 & 0.135 & 0.207 & 1.200 & 17.000 & 0.000 & 0.000 \\
\hline $6 X-1,74$ & 39.74 & 0.234 & 0.119 & 0.135 & 0.207 & 1.200 & 17.000 & 0.000 & 0.000 \\
\hline $6 \mathrm{X}-2,69$ & 41.19 & 0.234 & 0.119 & 0.135 & 0.207 & 1.200 & 17.000 & 0.000 & 0.000 \\
\hline $6 \mathrm{X}-3,130$ & 43.30 & 0.234 & 0.119 & 0.135 & 0.207 & 1.200 & 17.000 & 0.000 & 0.000 \\
\hline $6 \times-4,54$ & 44.04 & 0.234 & 0.119 & 0.135 & 0.207 & 1.200 & 17.000 & 0.000 & 0.000 \\
\hline $6 \mathrm{X}-5,20$ & 45.20 & 0.234 & 0.119 & 0.135 & 0.207 & 1.200 & 17.000 & 0.000 & 0.000 \\
\hline $7 X-1,56$ & 49.06 & 0.234 & 0.119 & 0.135 & 0.207 & 1.200 & 17.000 & 0.000 & 0.000 \\
\hline $7 \mathrm{X}-2,28$ & 50.28 & 0.234 & 0.119 & 0.135 & 0.207 & 1.200 & 17.000 & 0.000 & 0.000 \\
\hline $7 X-2,124$ & 51.24 & 0.234 & 0.119 & 0.135 & 0.207 & 1.200 & 17.000 & 0.000 & 0.000 \\
\hline $7 X-3,28$ & 51.78 & 0.234 & 0.119 & 0. & 0. & 1.200 & 17 & 0.000 & 0.000 \\
\hline $7 \times-3,125$ & 52.75 & 0.234 & 0.119 & 0.135 & 0.207 & 1.200 & 17.000 & 0.000 & 0.000 \\
\hline $7 \times-4,28$ & 53.30 & 0.234 & 0.119 & 0.135 & 0.207 & 1.200 & 17.000 & 0.000 & 0.000 \\
\hline $7 X-4,125$ & 54.27 & 0.246 & 0.135 & 0.151 & 0.220 & 1.150 & 0.000 & 0.000 & 0.000 \\
\hline $7 X-5,130$ & 55.82 & 0.344 & 0.204 & 0.200 & 0.268 & 0.800 & 6.000 & 0.000 & 0.000 \\
\hline $7 X-6,24$ & 56.26 & 0.180 & 0.108 & 0. & 0.3 & 1.200 & 37.000 & 0.000 & 0.000 \\
\hline $7 X-6,117$ & 57.19 & 0.219 & 0.135 & 0.144 & 0.270 & 0.935 & 11.500 & 0.000 & 0.000 \\
\hline $7 X-7,17$ & 57.69 & 0.219 & 0.135 & 0.144 & 0.270 & 0.935 & 11.500 & 0.000 & 0.000 \\
\hline $8 \times-1,23$ & 58.23 & 0.219 & 0.135 & 0.144 & 0.270 & 0.935 & 11.500 & 0.000 & 0.000 \\
\hline $8 \mathrm{X}-1,130$ & 59.30 & 0.219 & 0.135 & 0.144 & 0.270 & 0.935 & 11.500 & 0.000 & 0.000 \\
\hline $8 \mathrm{X}-2,37$ & 59.87 & 0.219 & 0.135 & 0.144 & 0.270 & 0.935 & 11.500 & 0.000 & 0.000 \\
\hline $8 X-2,110$ & 60.00 & 0.107 & 0.092 & 0.096 & 0.260 & & 3 & 0.000 & 0.000 \\
\hline $8 X-3,23$ & 61.23 & 0.107 & 0.092 & 0.096 & 0.260 & 0.590 & 3.000 & 0.000 & 0.000 \\
\hline $8 X-3,138$ & 62.28 & 0.107 & 0.092 & 0.096 & 0.260 & 0.590 & 3.000 & 0.000 & 0.000 \\
\hline $8 X-4,48$ & 62.98 & 0.107 & 0.092 & 0.096 & 0.260 & 0.590 & 3.000 & 0.000 & 0.000 \\
\hline $8 X-4,126$ & 63.76 & 0.107 & 0.092 & 0.096 & 0.260 & 0.590 & 3.000 & 0.000 & 0.000 \\
\hline $8 \times-5,56$ & 64.56 & 0.107 & 0.092 & 0.096 & 0.260 & 0.590 & 3.000 & 0.000 & -0.000 \\
\hline $9 \overline{X-1}, \overline{37}$ & $\overline{67} .8 \overline{7}$ & $0.3 \overline{00}$ & $0 . \overline{195}$ & $\overline{0.285}$ & $0.5 \overline{80}$ & $4 . \overline{200}$ & $1 \overline{6.000}$ & $\overline{0} .000$ & $0 . \overline{000}$ \\
\hline $9 \times-1,55$ & 68. & & & & & & & 0. & 000 \\
\hline $11 X-1,40$ & 78.40 & 0.300 & 0.195 & 0.285 & 0.580 & 4.200 & 16. & 0.000 & 0.000 \\
\hline $11 X-1,130$ & 79.30 & 0.300 & 0.195 & 0.285 & 0.580 & 4.200 & 16.000 & 0.000 & 0.000 \\
\hline $11 X-2,30$ & 79.80 & 0.300 & 0.195 & 0.285 & 0.580 & 4.200 & 16.000 & 0.000 & 0.000 \\
\hline $11 X-2,55$ & 80.05 & 0.300 & 0.195 & 0.2 & 0.580 & 4.200 & 16.000 & 0.000 & 0.000 \\
\hline $11 X-2,14$ & 80.59 & 0.3 & & & & 4.2 & & 0.0 & 0.000 \\
\hline $11 X-3,46$ & 80.91 & 0.300 & 0.195 & 0.285 & 0.5 & 4.200 & 16.0 & 0.000 & 0.000 \\
\hline $12 X-1,15$ & 87.65 & 0.300 & 0.195 & 0.285 & 0.5 & 4.200 & 16.0 & 0.000 & 0.000 \\
\hline $12 \mathrm{X}-\mathrm{CC}, 20$ & 88.35 & 0.300 & 0.195 & 0.285 & 0.5 & 4.200 & 16.000 & 0.000 & 0.000 \\
\hline $13 \mathrm{X}-1,15$ & 97.15 & 0. & 0.195 & 0.285 & 0.5 & 4.200 & 16.000 & 0.000 & 0.000 \\
\hline $13 \mathrm{X}-2$, & 97.79 & 0 . & 0. & 0.2 & 0. & 4.2 & 16.0 & 0.000 & 0.000 \\
\hline $13 \mathrm{X}-3,50$ & 98.36 & 0. & 0.1 & 0.2 & 0. & 4.200 & 16. & 0.000 & 0.000 \\
\hline $13 X-4,110$ & 99.88 & 0. & 0.195 & 0.285 & 0.5 & 4.200 & 16.000 & 0.000 & 0.000 \\
\hline 5,7 & 100.16 & 0.3 & 0 . & 0.2 & 0.5 & 4.2 & 16.000 & 0.000 & 0.000 \\
\hline 5,75 & i & 0. & 0. & 0.2 & 0. & 4.2 & 16.000 & 0.000 & 0.000 \\
\hline $13 \mathrm{X}-6,24$ & 101.18 & 0.3 & 0.1 & 0.2 & 0.5 & 4.2 & 16.0 & 0.000 & 0.000 \\
\hline $13 \times-6,50$ & & 0.31 & 0.1 & 0.2 & & 4.2 & & 0.000 & 0. \\
\hline 7,30 & 102.25 & 0.30 & 0.1 & 0.2 & 0.5 & 4.200 & 16.000 & 0.000 & 0.000 \\
\hline 8,25 & is & 0 & 0,1 & 0.2 & 0.5 & 4.200 & 16.000 & 0.000 & 0.000 \\
\hline CC, 40 & & 0. & 0.1 & 0.2 & 0.5 & 4.2 & 16.000 & 0.000 & 0.000 \\
\hline $15 \mathrm{X}-1,38$ & 116.38 & 0. & 0.1 & 0.2 & 0.5 & 4.2 & 16.000 & 0.000 & 0.000 \\
\hline $15 \mathrm{X}-1,70$ & 116.70 & 0.300 & 0.1 & & 0.5 & 4.2 & & 0.0 & 0.000 \\
\hline & & $0_{3}$ & & 0. & 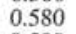 & 4.2 & 16.000 & 0.000 & 0.000 \\
\hline & 12 & 0.36 & 0.1 & & 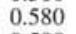 & 4.2 & 16.000 & 0.000 & 0.000 \\
\hline & & 0.3 & 0.1 & 0.2 & & 4.2 & 16.0 & 0.000 & 0.000 \\
\hline 1,16 & 14 & 0. & 0.1 & 0.2 & & 4.2 & 16.0 & 0.000 & 0.000 \\
\hline 1,46 & 144.96 & 0.30 & 0.1 & 0.2 & 0.5 & 4.200 & 16.000 & 0.000 & 0.000 \\
\hline & & 0.3 & & 0.2 & & 4.2 & 16. & 0.0 & 0.000 \\
\hline & & 0 & 0.1 & 0.2 & 05 & 4.200 & 16. & 0.000 & 0.000 \\
\hline & & & & & & 4.200 & & 0.000 & 0.000 \\
\hline 1,95 & .45 & 0.3 & 0.1 & 0.2 & 0.3 & 0.600 & 7.300 & 39.000 & 170.000 \\
\hline$-1,130$ & 164.80 & 0.38 & 0.1 & 0.2 & 0.5 & 4.200 & 16.000 & 0.000 & 0.000 \\
\hline & 165. & 0.38 & 0.1 & 0.2 & 0.5 & 4.200 & 16.000 & 0.000 & 0.000 \\
\hline & & 0.3 & 0.1 & 0.2 & 0.5 & 4.2 & 16. & 0.000 & 0.000 \\
\hline 28 & & & 0.1 & 0.2 & & 4.2 & & 0.000 & 0.000 \\
\hline 20X-CC, 18 & 167.27 & 0.300 & 0.195 & 0.285 & 0.580 & 4.200 & 16.000 & 0.000 & 0.000 \\
\hline
\end{tabular}

Notes: Numbers in bold represent the calibrated compensation factors. Solid lines $=$ unit boundaries; dashed lines $=$ subunit boundaries. $\mathrm{Tr}=$ transitional $u$ unit. 
APPENDIX B (continued).

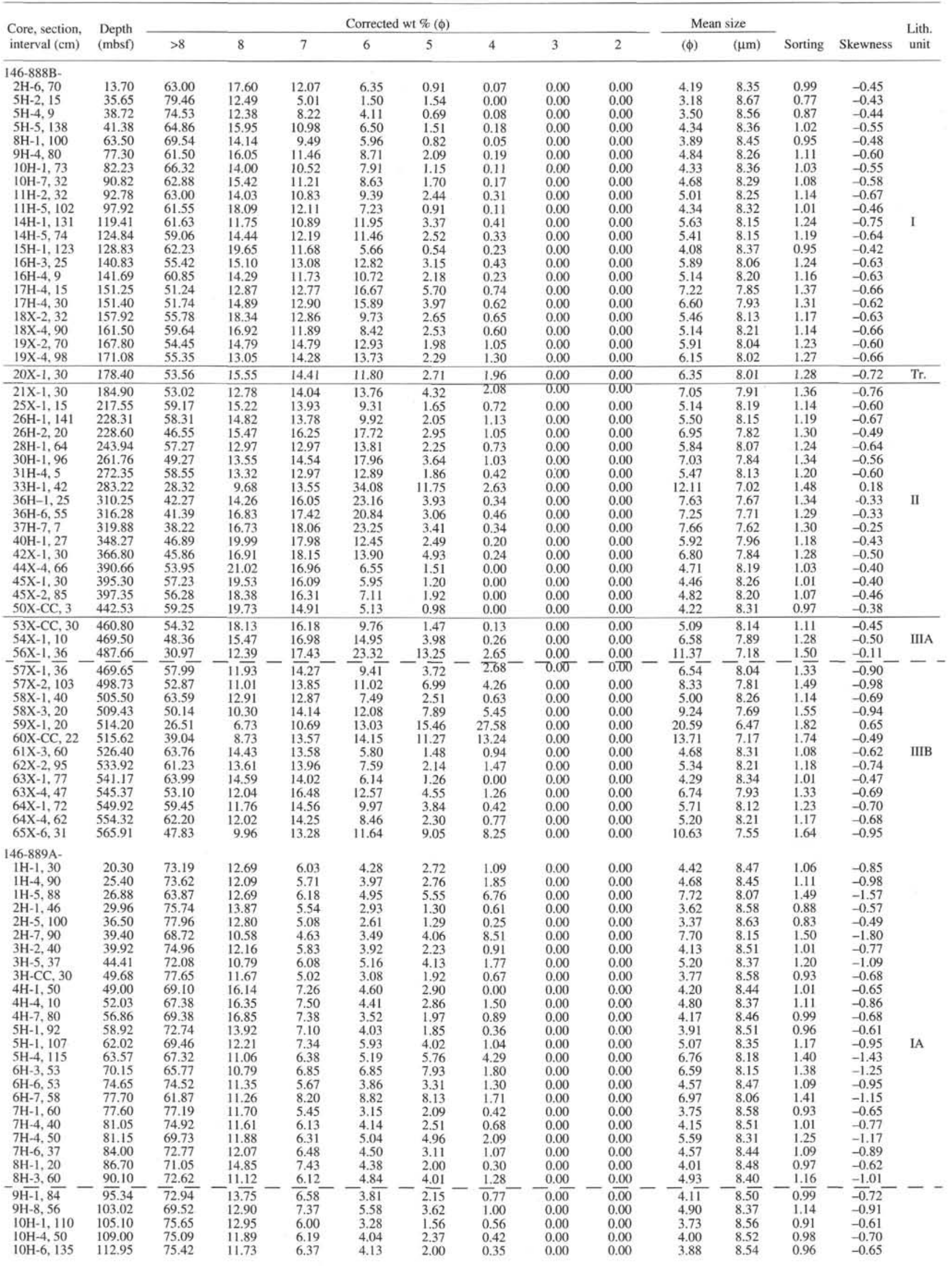


APPENDIX B (continued).

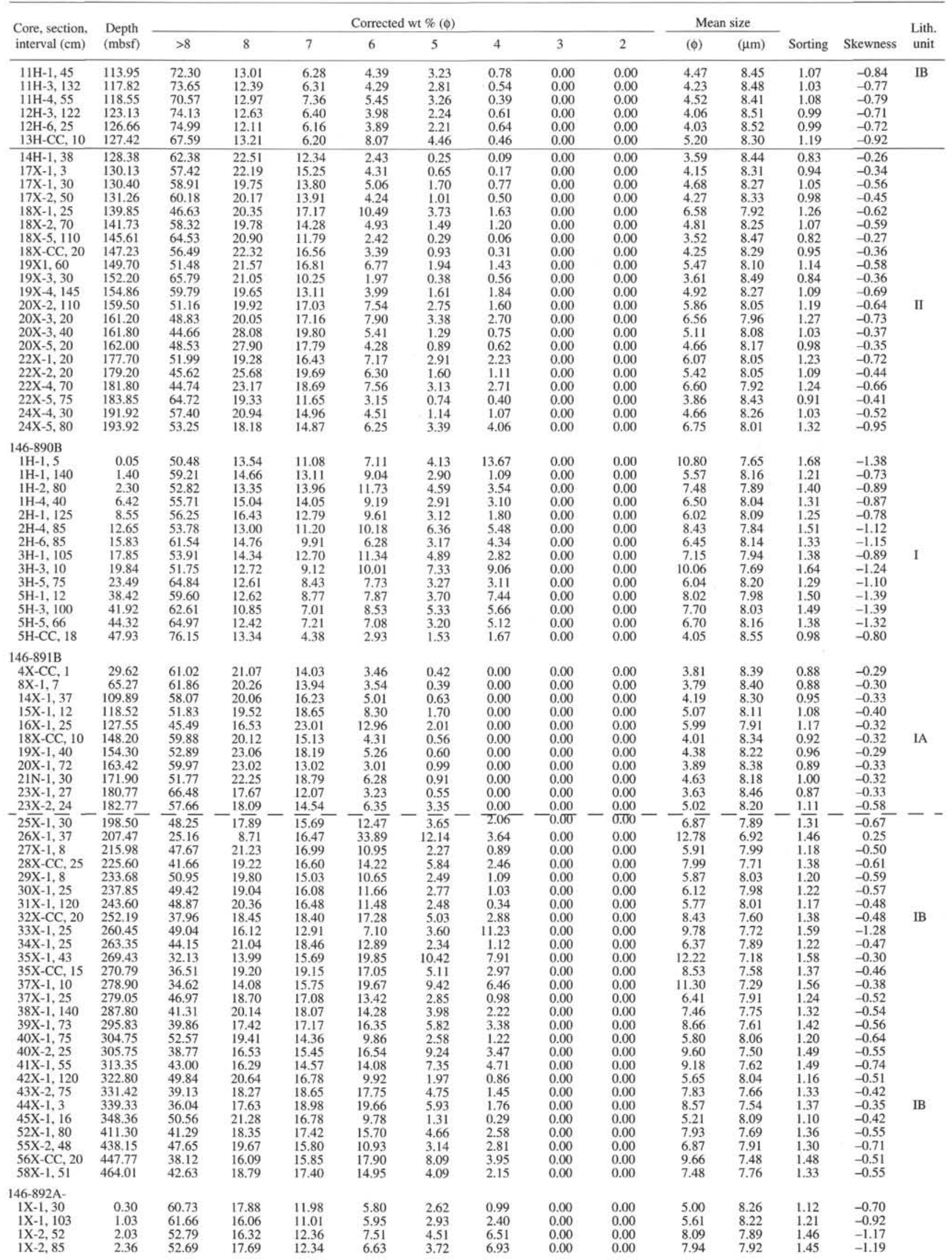


APPENDIX B (continued)。

\begin{tabular}{|c|c|c|c|c|c|c|c|c|c|c|c|c|c|c|}
\hline ction, & Depth & & & & Correct & $t \%(\phi)$ & & & & & size & & & Lith. \\
\hline interval (cm) & (mbsf) & $>8$ & 8 & 7 & 6 & 5 & 4 & 3 & 2 & $(\phi)$ & $(\mu \mathrm{m})$ & Sorting & Skewness & unit \\
\hline $1 X-3,33$ & 3.30 & 56.13 & 19.81 & 13.09 & 6.01 & 2.56 & 2.40 & 0.00 & 0.00 & 5.70 & 8.15 & 1.20 & -0.81 & \\
\hline $1 X-4,5$ & 3.59 & 58.76 & 20.57 & 11.86 & 4.93 & 1.99 & 1.88 & 0.00 & 0.00 & 5.12 & 8.24 & 1.12 & -0.73 & \\
\hline IX $-5,30$ & 4.00 & 60.55 & 16.48 & 11.68 & 5.71 & 2.21 & 3.38 & 0.00 & 0.00 & 5.82 & 8.19 & 1.24 & -0.96 & \\
\hline 1X-CC, 5 & 4.24 & 63.75 & 16.75 & 10.47 & 4.80 & 1.66 & 2.58 & 0.00 & 0.00 & 5.14 & 8.30 & 1.14 & -0.87 & \\
\hline $2 X-1,14$ & 9.64 & 59.13 & 17.42 & 11.95 & 5.82 & 2.17 & 3.51 & 0.00 & 0.00 & 5.92 & 8.17 & 1.24 & -0.95 & \\
\hline $2 X-1,50$ & 10.00 & 59.71 & 18.61 & 12.69 & 5.36 & 1.47 & 2.17 & 0.00 & 0.00 & 5.15 & 8.24 & 1.13 & -0.74 & \\
\hline $2 X-1,70$ & 10.20 & 65.79 & 18.89 & 11.82 & 0.45 & 1.07 & 1.98 & 0.00 & 0.00 & 4.25 & 8.43 & 0.97 & -0.64 & \\
\hline $2 X-2,130$ & 12.30 & 63.61 & 19.16 & 10.64 & 3.59 & 1.02 & 1.97 & 0.00 & 0.00 & 4.60 & 8.36 & 1.05 & -0.70 & \\
\hline $2 \mathrm{X}-3,55$ & 13.05 & 67.45 & 17.94 & 9.55 & 3.03 & 0.81 & 1.22 & 0.00 & 0.00 & 4.05 & 8.45 & 0.95 & -0.58 & \\
\hline $3 X-1,10$ & 19.10 & 62.43 & 15.50 & 11.27 & 5.47 & 2.28 & 3.04 & 0.00 & 0.00 & 5.63 & 8.23 & 1.22 & -0.96 & \\
\hline $3 X-1,120$ & 20.20 & 64.10 & 17.07 & 10.87 & 4.53 & 1.58 & 1.86 & 0.00 & 0.00 & 4.81 & 8.33 & 1.09 & -0.76 & \\
\hline $3 X-2,17$ & 20.67 & 65.68 & 16.10 & 10.25 & 4.29 & 1.48 & 2.20 & 0.00 & 0.00 & 4.84 & 8.35 & 1.10 & -0.81 & \\
\hline $3 X-2,105$ & 21.55 & 57.50 & 15.36 & 10.83 & 9.50 & 5.77 & 1.04 & 0.00 & 0.00 & 6.32 & 8.07 & 1.31 & -0.88 & \\
\hline $3 \mathrm{X}-3,32$ & 22.12 & 68.94 & 15.19 & 9.69 & 3.79 & 1.26 & 1.13 & 0.00 & 0.00 & 4.21 & 8.44 & 1.00 & -0.65 & \\
\hline $3 X-3,77$ & 22.57 & 64.69 & 16.16 & 10.03 & 3.82 & 1.24 & 4.07 & 0.00 & 0.00 & 5.47 & 8.29 & 1.19 & -1.03 & \\
\hline $4 X-1,5$ & 28.55 & 59.11 & 18.40 & 12.61 & 4.83 & 1.88 & 3.18 & 0.00 & 0.00 & 5.62 & 8.20 & 1.19 & -0.89 & \\
\hline $4 X-1,40$ & 28.90 & 62.26 & 17.85 & 12.10 & 4.56 & 1.98 & 1.25 & 0.00 & 0.00 & 4.76 & 8.31 & 1.08 & -0.68 & \\
\hline $4 X-2,25$ & 29.70 & 64.50 & 15.86 & 10.76 & 4.32 & 2.66 & 1.90 & 0.00 & 0.00 & 5.08 & 8.30 & 1.14 & -0.85 & \\
\hline $4 X-2,60$ & 31.12 & 63.36 & 17.66 & 11.12 & 4.09 & 2.06 & 1.72 & 0.00 & 0.00 & 4.85 & 8.32 & 1.10 & -0.76 & \\
\hline $6 X-1,25$ & 39.25 & 58.10 & 15.42 & 13.18 & 6.82 & 4.56 & 1.93 & 0.00 & 0.00 & 6.12 & 8.11 & 1.27 & -0.89 & IA \\
\hline $6 X-1,74$ & 39.74 & 61.69 & 18.08 & 13.21 & 5.08 & 1.63 & 0.32 & 0.00 & 0.00 & 4.41 & 8.32 & 1.02 & -0.51 & \\
\hline $6 X-2,69$ & 41.19 & 68.04 & 17.61 & 10.18 & 2.89 & 0.90 & 0.38 & 0.00 & 0.00 & 3.74 & 8.48 & 0.89 & -0.44 & \\
\hline $6 X-3,130$ & 43.30 & 52.17 & 18.48 & 16.24 & 7.99 & 3.41 & 1.71 & 0.00 & 0.00 & 6.09 & 8.04 & 1.23 & -0.70 & \\
\hline $6 \times-4,54$ & 44.04 & 57.80 & 17.22 & 14.48 & 6.12 & 2.97 & 1.42 & 0.00 & 0.00 & 5.45 & 8.17 & 1.17 & -0.73 & \\
\hline $6 X-5,20$ & 45.20 & 62.29 & 18.08 & 12.05 & 4.67 & 1.98 & 0.92 & 0.00 & 0.00 & 4.64 & 8.32 & 1.06 & -0.63 & \\
\hline $7 X-1,56$ & 49.06 & 59.62 & 16.06 & 12.95 & 6.36 & 3.58 & 1.43 & 0.00 & 0.00 & 5.56 & 8.18 & 1.20 & -0.81 & \\
\hline $7 X-2,28$ & 50.28 & 63.43 & 18.93 & 11.92 & 3.87 & 1.09 & 0.76 & 0.00 & 0.00 & 4.21 & 8.38 & 0.98 & -0.52 & \\
\hline $7 \mathrm{X}-2,124$ & 51.24 & 58.71 & 18.54 & 13.98 & 6.02 & 2.04 & 0.69 & 0.00 & 0.00 & 4.87 & 8.24 & 1.09 & -0.58 & \\
\hline $7 X-3,28$ & 51.78 & 62.18 & 17.93 & 12.76 & 4.78 & 1.59 & 0.76 & 0.00 & 0.00 & 4.51 & 8.32 & 1.04 & -0.57 & \\
\hline $7 X-3,125$ & 52.75 & 63.69 & 19.01 & 12.10 & 3.65 & 0.99 & 0.56 & 0.00 & 0.00 & 4.08 & 8.39 & 0.95 & -0.47 & \\
\hline $7 X-4,28$ & 53.30 & 58.44 & 19.84 & 12.17 & 5.15 & 3.67 & 0.73 & 0.00 & 0.00 & 5.15 & 8.22 & 1.13 & -0.71 & \\
\hline $7 X-4,125$ & 54.27 & 60.96 & 20.04 & 13.03 & 4.50 & 1.47 & 0.00 & 0.00 & 0.00 & 4.17 & 8.35 & 0.97 & -0.43 & \\
\hline $7 X-5,130$ & 55.82 & 51.17 & 21.37 & 16.85 & 8.02 & 1.96 & 0.61 & 0.00 & 0.00 & 5.30 & 8.10 & 1.11 & -0.49 & \\
\hline $7 X-6,24$ & 56.26 & 53.08 & 19.69 & 14.34 & 9.26 & 1.97 & 1.67 & 0.00 & 0.00 & 5.74 & 8.08 & 1.19 & -0.65 & \\
\hline $7 X-6,117$ & 57.19 & 61.78 & 17.61 & 11.17 & 5.98 & 2.07 & 1.39 & 0.00 & 0.00 & 4.98 & 8.28 & 1.12 & -0.73 & \\
\hline $7 X-7,17$ & 57.69 & 55.91 & 17.26 & 12.24 & 7.82 & 3.94 & 2.83 & 0.00 & 0.00 & 6.43 & 8.06 & 1.30 & -0.93 & \\
\hline $8 \mathrm{X}-1,23$ & 58.23 & 62.63 & 18.93 & 11.51 & 5.27 & 1.36 & 0.32 & 0.00 & 0.00 & 4.27 & 8.35 & 0.99 & -0.50 & \\
\hline $8 \times-1,130$ & 59.30 & 59.77 & 18.85 & 12.11 & 6.04 & 1.77 & 1.46 & 0.00 & 0.00 & 5.01 & 8.25 & 1.11 & -0.69 & \\
\hline $8 X-2,37$ & 59.87 & 62.09 & 18.42 & 11.43 & 5.50 & 1.68 & 0.89 & 0.00 & 0.00 & 4.62 & 8.32 & 1.06 & -0.62 & \\
\hline $8 X-2,110$ & 60.00 & 49.78 & 21.88 & 14.86 & 10.94 & 2.04 & 0.51 & 0.00 & 0.00 & 5.57 & 8.05 & 1.15 & -0.50 & \\
\hline $8 X-3,23$ & 61.23 & 54.84 & 21.20 & 12.43 & 8.90 & 1.94 & 0.69 & 0.00 & 0.00 & 5.19 & 8.16 & 1.12 & -0.58 & IA \\
\hline $8 \times-3,138$ & 62.28 & 50.28 & 20.87 & 14.26 & 11.35 & 2.54 & 0.70 & 0.00 & 0.00 & 5.80 & 8.03 & 1.19 & -0.56 & \\
\hline $8 X-4,48$ & 62.98 & 50.15 & 22.75 & 14.44 & 10.22 & 2.00 & 0.44 & 0.00 & 0.00 & 5.42 & 8.08 & 1.13 & -0.50 & \\
\hline $8 X-4,126$ & 63.76 & 51.54 & 22.09 & 13.79 & 10.09 & 2.12 & 0.37 & 0.00 & 0.00 & 5.36 & 8.10 & 1.13 & -0.51 & \\
\hline $8 X-5,56$ & 64.56 & 45.63 & 20.82 & 14.75 & 12.88 & 4.11 & 1.79 & 0.00 & 0.00 & 6.95 & 7.87 & 1.30 & -0.64 & \\
\hline $9 \overline{\mathrm{X}-1}, \overline{37}$ & $\overline{67.87}$ & $45 . \overline{20}$ & $1 \overline{7.80}$ & $\overline{16.00}$ & $9 . \overline{32}$ & $\overline{8.10}$ & 3.58 & 0.00 & 0.00 & 8.39 & $7 . \overline{74}$ & $1 . \overline{44}$ & $\overline{-0.84}$ & \\
\hline $9 \mathrm{X}-1,55$ & 68.05 & 39.08 & 18.07 & 20.30 & 12.69 & 7.39 & 2.46 & 0.00 & 0.00 & 8.42 & 7.63 & 1.39 & -0.55 & \\
\hline $11 X-1,40$ & 78.40 & 45.95 & 15.07 & 14.32 & 9.39 & 10.23 & 5.05 & 0.00 & 0.00 & 9.48 & 7.65 & 1.55 & -0.92 & \\
\hline $11 X-1,130$ & 79.30 & 55.53 & 17.66 & 15.16 & 7.45 & 3.86 & 0.33 & 0.00 & 0.00 & 5.49 & 8.13 & 1.17 & -0.63 & \\
\hline $11 X-2,30$ & 79.80 & 54.48 & 21.09 & 15.31 & 6.60 & 2.44 & 0.09 & 0.00 & 0.00 & 4.93 & 8.18 & 1.08 & -0.49 & \\
\hline $11 X-2,55$ & 80.05 & 53.27 & 18.44 & 14.74 & 6.89 & 4.61 & 2.06 & 0.00 & 0.00 & 6.34 & 8.04 & 1.27 & -0.82 & \\
\hline $11 X-2,14$ & 80.59 & 56.07 & 19.29 & 15.12 & 6.48 & 2.59 & 0.45 & 0.00 & 0.00 & 5.06 & 8.19 & 1.11 & -0.56 & \\
\hline $11 X-3,46$ & 80.91 & 55.86 & 19.01 & 14.96 & 6.51 & 3.04 & 0.62 & 0.00 & 0.00 & 5.26 & 8.17 & 1.14 & -0.62 & \\
\hline $12 X-1,15$ & 87.65 & 59.66 & 18.34 & 13.50 & 5.68 & 2.49 & 0.34 & 0.00 & 0.00 & 4.77 & 8.26 & 1.08 & -0.58 & \\
\hline $12 \mathrm{X}-\mathrm{CC}, 20$ & 88.35 & 57.14 & 16.70 & 13.10 & 6.77 & 4.88 & 1.40 & 0.00 & 0.00 & 6.00 & 8.11 & 1.25 & -0.85 & \\
\hline $13 \mathrm{X}-1,15$ & 97.15 & 45.30 & 16.63 & 15.28 & 7.23 & 9.12 & 6.44 & 0.00 & 0.00 & 9.54 & 7.66 & 1.54 & -1.00 & \\
\hline $13 X-2,50$ & 97.79 & 58.10 & 21.96 & 14.12 & 4.45 & 1.28 & 0.09 & 0.00 & 0.00 & 4.25 & 8.31 & 0.96 & -0.40 & \\
\hline $13 \mathrm{X}-3,50$ & 98.36 & 61.67 & 17.30 & 12.97 & 5.35 & 2.50 & 0.22 & 0.00 & 0.00 & 4.63 & 8.30 & 1.06 & -0.58 & \\
\hline $13 X-4,110$ & 99.88 & 56.73 & 17.08 & 14.13 & 6.73 & 3.85 & 1.47 & 0.00 & 0.00 & 5.79 & 8.12 & 1.22 & -0.78 & \\
\hline $13 \times-5,7$ & 100.16 & 58.20 & 16.70 & 14.02 & 6.63 & 4.04 & 0.40 & 0.00 & 0.00 & 5.37 & 8.17 & 1.17 & -0.69 & \\
\hline $13 X-5,75$ & 100.84 & 57.83 & 17.79 & 13.99 & 6.56 & 3.02 & 0.81 & 0.00 & 0.00 & 5.26 & 8.19 & 1.15 & -0.67 & \\
\hline $13 X-6,24$ & 101.18 & 60.80 & 17.82 & 11.39 & 4.14 & 3.94 & 1.90 & 0.00 & 0.00 & 5.50 & 8.23 & 1.19 & -0.90 & \\
\hline $13 X-6,50$ & 101.44 & 58.86 & 18.58 & 13.67 & 5.83 & 2.84 & 0.21 & 0.00 & 0.00 & 4.85 & 8.24 & 1.09 & -0.58 & IB \\
\hline $13 \mathrm{X}-7,30$ & 102.25 & 54.03 & 17.87 & 14.34 & 7.22 & 4.67 & 1.87 & 0.00 & 0.00 & 6.29 & 8.05 & 1.27 & -0.82 & \\
\hline $13 X-8,25$ & 103.70 & 53.81 & 18.41 & 14.45 & 7.09 & 4.62 & 1.62 & 0.00 & 0.00 & 6.17 & 8.06 & 1.26 & -0.79 & \\
\hline $13 \mathrm{X}-\mathrm{CC}, 40$ & 105.17 & 55.48 & 18.21 & 14.28 & 6.73 & 4.36 & 0.94 & 0.00 & 0.00 & 5.75 & 8.11 & 1.21 & -0.74 & \\
\hline $15 \mathrm{X}-1,38$ & 116.38 & 51.60 & 17.57 & 16.14 & 8.80 & 5.15 & 0.74 & 0.00 & 0.00 & 6.27 & 8.00 & 1.26 & -0.68 & \\
\hline $15 X-1,70$ & 116.70 & 54.67 & 18.50 & 15.33 & 7.21 & 3.69 & 0.60 & 0.00 & 0.00 & 5.54 & 8.12 & 1.17 & -0.64 & \\
\hline $16 \times-1,30$ & 125.80 & 58.82 & 20.47 & 13.08 & 4.69 & 2.03 & 0.91 & 0.00 & 0.00 & 4.76 & 8.27 & 1.06 & -0.60 & \\
\hline $16 \mathrm{X}-\mathrm{CC}, 20$ & 126.13 & 56.09 & 20.90 & 13.57 & 5.41 & 3.00 & 1.04 & 0.00 & 0.00 & 5.23 & 8.19 & 1.13 & -0.67 & \\
\hline $17 X-2,66$ & 136.27 & 54.26 & 21.58 & 15.81 & 5.60 & 2.24 & 0.51 & 0.00 & 0.00 & 4.95 & 8.19 & 1.07 & -0.51 & \\
\hline $18 X-1,16$ & 144.66 & 45.98 & 17.22 & 16.62 & 10.41 & 8.36 & 1.42 & 0.00 & 0.00 & 7.73 & 7.79 & 1.39 & -0.72 & \\
\hline $18 X-1,46$ & 144.96 & 56.17 & 15.54 & 12.88 & 6.24 & 6.91 & 2.26 & 0.00 & 0.00 & 6.84 & 8.02 & 1.36 & -1.01 & \\
\hline $18 X-1,96$ & 145.46 & 56.48 & 19.15 & 14.58 & 6.09 & 3.03 & 0.67 & 0.00 & 0.00 & 5.20 & 8.18 & 1.13 & -0.63 & \\
\hline $20 X-1,28$ & 163.78 & 46.90 & 16.25 & 14.41 & 8.41 & 9.42 & 4.61 & 0.00 & 0.00 & 8.95 & 7.71 & 1.51 & -0.96 & \\
\hline $20 X-1,70$ & 164.20 & 52.16 & 19.13 & 16.14 & 7.85 & 3.89 & 0.82 & 0.00 & 0.00 & 5.84 & 8.06 & 1.20 & -0.64 & \\
\hline $20 \mathrm{X}-1,95$ & 164.45 & 46.60 & 15.79 & 15.43 & 9.50 & 3.22 & 4.53 & 4.09 & 0.85 & 12.32 & 7.64 & 1.67 & -1.76 & \\
\hline $20 \mathrm{X}-1,130$ & 164.80 & 48.56 & 20.42 & 17.35 & 8.00 & 4.34 & 1.34 & 0.00 & 0.00 & 6.30 & 7.98 & 1.24 & -0.65 & \\
\hline $20 \mathrm{X}-2,23$ & 165.25 & 53.35 & 20.53 & 16.10 & 6.90 & 2.79 & 0.33 & 0.00 & 0.00 & 5.21 & 8.14 & 1.11 & -0.53 & \\
\hline $20 \mathrm{X}-2,60$ & 165.62 & 57.77 & 18.88 & 14.05 & 5.98 & 3.04 & 0.28 & 0.00 & 0.00 & 4.98 & 8.22 & 1.10 & -0.59 & \\
\hline $20 X-2,142$ & 166.44 & 56.26 & 18.88 & 15.05 & 6.54 & 2.94 & 0.34 & 0.00 & 0.00 & 5.11 & 8.18 & 1.12 & -0.58 & \\
\hline 20X-CC, 18 & 167.27 & 52.80 & 18.79 & 16.21 & 8.04 & 3.55 & 0.63 & 0.00 & 0.00 & 5.68 & 8.08 & 1.18 & -0.61 & \\
\hline
\end{tabular}

Notes: Numbers in bold represent the calibrated compensation factors. Solid lines $=$ unit boundaries; dashed lines $=$ subunit boundaries. $\mathrm{Tr}=$ transitional unit. 